ISSN 2414-987X
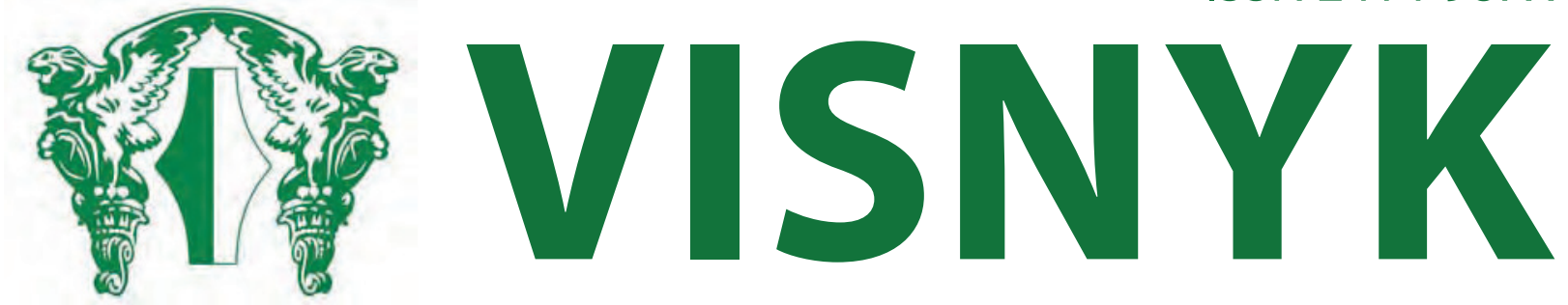

OF THE NATIONAL BANK OF UKRAINE

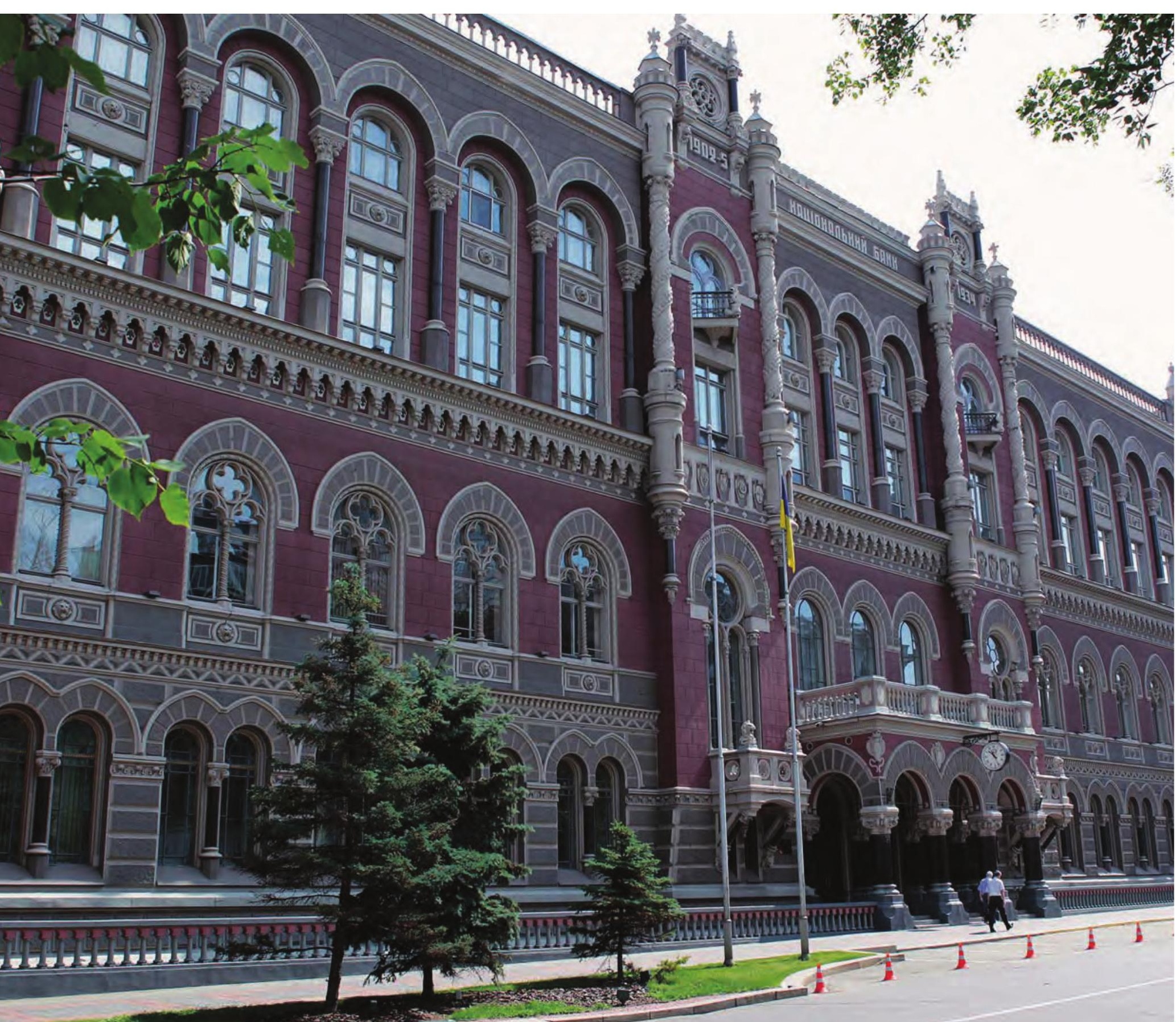

QUARTERLYRESEARCH

JOURNAL OF THE NATIONAL BANK OF UKRAINE 
Quarterly research Journal of the National Bank of Ukraine

Published since March 1995

\section{Editorial Board}

\section{Dmytro Sologub}

Chairman of the Editorial

Board,

Deputy Governor,

\section{Vladyslav Rashkovan}

Deputy Governor, the National

Bank of Ukraine

\section{Vitaliy Vavryshchuk}

Director of Financial Stability

Department, the National Bank of Ukraine

\section{Yuriy Gorodnichenko}

Associate Professor, University of

California, Berkeley, PhD

\section{Oleksandr Petryk}

Alternative Executive Director, the

International Monetary Fund, $\mathrm{PhD}$ the National Bank of Ukraine
Sergiy Nikolaychuk

Deputy Chairman,

Director of Monetary Policy

and Economic

Analysis Department, the National Bank

of Ukraine, $\mathrm{PhD}$

\section{Oleksiy Kryvtsov}

Director in the International

Economic Analysis Department,

Bank of Canada, PhD

\section{Tom Coupe}

Associate Professor, Senior Economist, the Kyiv School of Economics, PhD
(C) National Bank of Ukraine 1995-2016

All rights reserved

https://doi.org/10.26531/vnbu2016.235

Address: 9 Instytutska Street, Kyiv, 01601, Ukraine Email: journal@bank.gov.ua

Design and layout:

"INPRESS" LLC.

Address: 46 Zolotoustivska st., Apt. 7, Kyiv, 01135, Ukraine.

Tel.: +380 (44) 234-78-68.

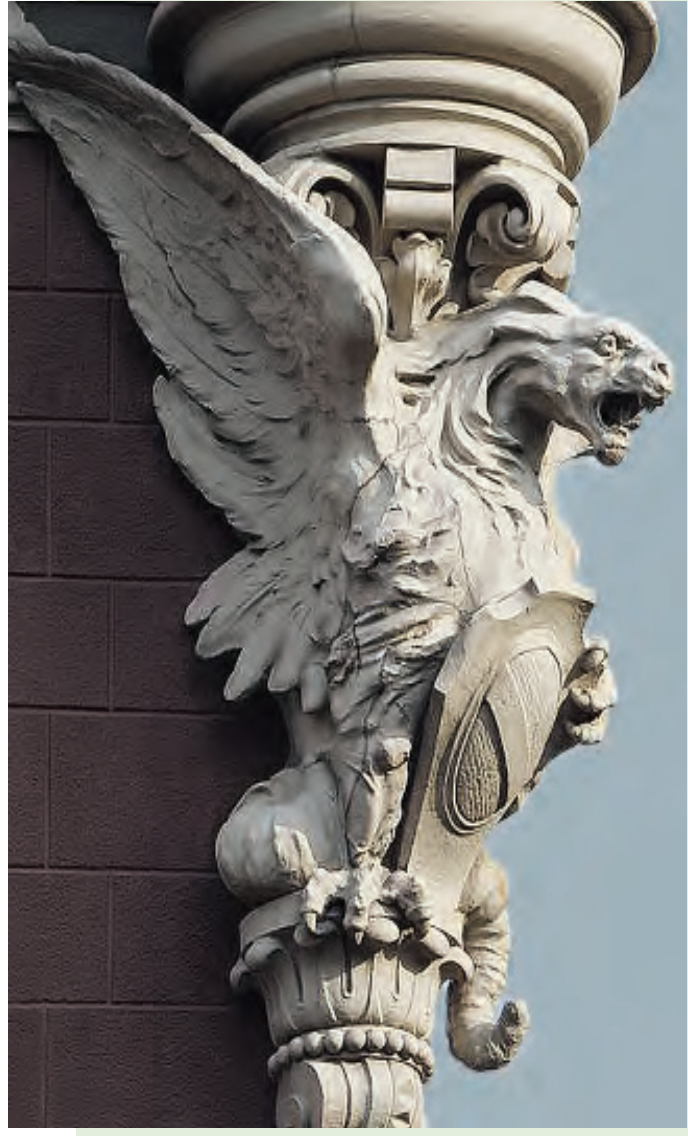

Founder and publisher:

National Bank of Ukraine

Editorial board ensures compliance with ethical standards of publishing

For reprinting materials published herein the reference to the journal "Visnyk of the National Bank of Ukraine" is compulsory

The Editorial Board can publish materials being under discussion, not sharing the author's opinion

The author bears responsibility for the accuracy of the materials 


\section{PREFACE OF THE CHAIRMAN OF THE EDITORIAL BOARD}

\section{Dear readers,}

The articles of the current issue of the Visnyk of the National Bank of Ukraine are related to the scope of responsibility and regulatory activity of the National Bank of Ukraine, which continues phased reforms of Ukraine's banking sector and financial market. The roadmap to adopting inflation targeting says that the adoption of this regime requires reforms, in particular to support and ensure the independence of the National Bank of Ukraine, to gradually liberalize Ukraine's foreign exchange market, and to provide more analytical support to monetary policy decisions. This issue contains studies that propose ways of applying international experiences to Ukraine's domestic conditions, and give guidelines for addressing challenges that are particularly important for the National Bank of Ukraine.

This issue starts with an article by Viktor Koziuk entitled Independence of Central Banks in Commodity Economies that tests the hypothesis of lower level of independence of the central banks in resource-rich countries. The author concludes that richness in natural resources has a bearing on the level of a central bank's independence directly (depending on the share of raw materials in the country's exports), and indirectly (countries that are rich in natural resources tend to have a lower level of democracy, and, consequently, more dependent central banks). By grouping countries, the author establishes that such indicators of central bank independence as the GMT, ECWN, and transparency indices are lower for the group of economies that export raw materials, even compared to emerging and developing economies. The article's findings explain the significant influence that the orientation of Ukraine's economy to exports of raw materials had on the NBU's monetary policy in the past. The article also, once again, emphasizes the importance of recent changes that enhanced the NBU's independence for delivering price stability as the central bank's main contribution to the country's sustained economic growth.

The article by Maria Repko, Oleksandr Kashko, and Irina Piontkivska entitled International Experiences of Capital Flows Liberalization addresses such a regulatory tool as restrictions on capital movements. The article talks about global experiences in employing this tool and provides a summary of recommendations that international financial institutions have given in that regard. Given globalized economic processes and the high openness of the Ukrainian economy, foreign exchange reforms should be aimed at gradually liberalizing capital movements. This requires taking steps to increase the institutional capacity to manage both capital inflows and outflows at various stages of the liberalization process. The article is particularly relevant in light of the NBU's current project to liberalize the foreign exchange market. 
Roman Lysenko's and Nataliia Kolesnichenko's article Nowcasting of Economic Development Indicators Using the NBU's Business Survey Results examines the possibility of forecasting macroeconomic trends on the basis of surveys of enterprises that are carried out by the National Bank of Ukraine. Among other things, it outlines several techniques for calculating a leading indicator of economic activity, as well as the strengths and weaknesses of these techniques. The best indicator that ensures a high accuracy of short-term GDP projections has been chosen using econometric models.

The editorial staff hopes that the articles published in this issue will spark further discussions, encourage follow-up studies, and be useful for scholars and experts in banking and finance.

New authors are invited to submit their studies to the Visnyk of the National Bank of Ukraine. Relevant and interesting articles supported by sound findings and proposals are always welcome. 


\section{CONTENTS}

\section{Viktor Koziuk}

Independence of Central Banks

in Commodity Economies

Maria Repko, Oleksandr Kashko, Irina Piontkivska

International Experience of Capital Flows Liberalization

Roman Lysenko, Nataliia Kolesnichenko

Nowcasting of Economic Development Indicators

Using the NBU's Business Survey Results 


\title{
Independence of Central Banks in Commodity Economies
}

\author{
Viktor Koziuk \\ Ternopil National Economic University
}

\begin{abstract}
This article introduces the hypothesis that resource-rich countries display a low degree of central bank independence (CBI). This hypothesis is proven based on multivariable regression, but the influence of resource factors is not considered strong enough compared with previous inflationary experience and the characteristics of the political regime. It stresses that the impact of the commodity wealth factor on CBI choice is direct (through the share of commodity exports in total export) and indirect through the lower level of democracy in commodities countries that feature more dependent central banks. Also, this hypothesis is proven based on the grouping of countries. Such grouping shows that despite a general tendency of CBI increase in the world, a group of commodity exporting countries experiencing a substantially lower level of mean GMT-index, ECWNindex, and transparency-index resulted in lower CBI compared with groups of emerging markets and developing countries. Explaining these phenomena is rooted in features of institutional distortions in commodity economies, the specific structure of interventionist policy to overcome a "resource curse," and the specific role of the exchange rate and FX reserves in intertemporal macroeconomic policy.
\end{abstract}

\section{JEL Codes: E58, E59, 023, Q33}

Keywords: central bank independence, indexes of central bank independence, "resource curse", commodities export, exchange reserves, exchange rates, quality of institutions

\section{A. Introduction}

The instability of price trends for commodities increasingly corresponds to strengthening of globally-centric determinants of behavior of primary resources markets. Scales of fluctuations of prices for commodities, synchronization of cycles of price trends with the global liquidity cycle, and strengthening of the relationship between world prices for commodities, capital flows, and global financial imbalances prove that resource-rich countries, for which the export of commodities or semi-finished products made from them is important to the economy's structure, fall within a qualitatively different macrofinancial framework compared to countries, where fluctuations in terms of trade are not so essential and these fluctuations are not followed by significant changes of capital flows and their allocation. It is not a coincidence that, building on already established concepts of "Dutch disease" and "resource curse," the interests of commodity-exporting countries for macroeconomics has significantly risen during the last decade. It is proven both by special investigations of international financial organizations on optimal fiscal regimes for resource-rich countries and inclusive growth and steady development. In numerous publications, macroeconomic dilemmas of these countries are actually considered from a different point of view. The institutional, political, and economic aspects of analysis of the macroeconomic profile of commodity economies indicate that the benefits of "rent seeking" fully deform macroeconomic policy, due to which conventional macroeconomic tools often become direct welfare redistribution levers. Monetary policy authorities can be directly involved in redistributive political dilemmas or into realization of infrastructural projects and projects for economic diversification. The status of the central bank in commodity economies is being distorted under the influence of institutional deformities.

First, the central bank can come under pressure on account of the impact of serious fluctuations of commodity prices on internal monetary processes. A combination of serious fluctuations of export prices with fluctuations of terms of trade and reverses of capital flows should somehow correlate how the behavior of aggregate demand is being transmitted to inflation, economic growth, and employment. Analogously, how inflation behavior impacts export sector competitiveness through its 
impact on the real effective exchange rate is of the same importance. It is conceivable that scales of fluctuations of commodity prices and reverses of capital flows for the last 20 years are such that they inevitably influence inflation (deflation) pressure with appropriate consequences for formation of the inflation level as a medium-term tendency. In contrast to inflationary trends, given the level of commodity prices in global terms, the status of central banks can play a compensatory role that theoretically is more important than in other countries due to the procyclical nature of fluctuations of world commodity prices. Second, the institutional differences of commodity economies ispreciselywhy therein may consist an almost completely different nature of the relationship between the status of monetary authorities and macroeconomic choice. The mode of monetary and fiscal policy may be deformed owing to "rent seeking" (or protection of already "captured" rent) or to the necessity to implement a specific structural policy with purposes that may contradict conventional support of price stability by an independent central bank. Peculiarities of "external wealth" management also influence the specific institutional field of central bank operations. A conclusion can be made that the The level of CBI in commodity economies will be lower due to institutional deformities related to commodity wealth. Additionally, it is conceivable that the level of commodity wealth may indirectly impact the independence level and directly through the quality of institutions and existing political regime.

Considering the increasing role of the commodities sector in Ukraine (the role of metallurgy diminishes to some extent, and the role of agriculture increases in its place) and the expectation for transformation of the domestic agricultural complex into a global power (on one hand, there are relative benefits, on the other, there is global demand), the subjects of research on macroeconomic and institutional patterns in functioning resource-rich economies are of particular emphasis. Matters that reveal differences in basic institutional patterns of central banks in exporting countries alongside other countries and theoretic interpretation of such deviations are becoming more urgent.

The purpose of the article is to explain the lower level of $\mathrm{CBI}$ in commodity economies and to provide its empirical confirmation. This is especially urgent because, in the recent past, structural reforms in many countries have testified that there is a general trend to increase the autonomy level of monetary authorities.

In this article, the following hypothesis is made: in resource-rich countries there are specific macroeconomic priorities and institutional deformities affecting the favor of selection of a lower level $\mathrm{CBI}$, because a lower level of monetary autonomy is considered more functional. Theoretical arguments to the advantage of implementing a functionally less independent central bank, considering the general trend for increased monetary autonomy across the world, require further investigation. Empirical confirmation of a lower level of monetary autonomy will be supported by an intergroup comparison and a regression model. If in a group of resource-rich countries the average The level of $\mathrm{CBI}$ measured by means of an appropriate index is lower than on the average in a group of emerging market countries, it will demonstrate lower monetary autonomy. Regression analysis is intended to verify this dependence in a broad range of countries.

This article has the following structure: the next chapter contains a review of literature on the matters of empirical verification of the independence of central banks and the specific nature of macroeconomic analysis of commodity economies; chapter $\mathrm{C}$ presents a theoretical explanation of the functional view on more dependent central banks and an overview of the predominant trend for the rise of independence of central banks is offered; in chapter $D$, empirical verification of the hypothesis of a lower The level of $\mathrm{CBI}$ in commodity-rich countries is made; and chapter $\mathrm{E}$ provides conclusions.

\section{B. Theoretical framework of the investigation: review of literature}

\section{Independence of central banks and inflation: inside and outside the consensus}

Canonical investigations into the problem of the role of monetary authorities' status in determining inflation levels, which may be considered the first generation of such explorations in this direction, can be summarized as follows (Grilli et al., 1991; Cukierman et al., 1992; Eijffinger and Schaling, 1993):

a) The level of $\mathrm{CBI}$ is important for the inflation level and actually is neutral to rates of economic development;

b) The positive influence of monetary authorities' status on economic growth is provided by its relevance to the disinflation process and achievement of a fair monetary policy that is confirmed particularly clearly by the experiences of emerging market countries, in particular, post-socialistic European countries;

c) The proximity of the relationship between the index measuring the level of $\mathrm{CBI}$ and the inflation level is the closest in developed countries, which is caused by differences between the formal and the actual status;

d) Additional identifiers of the actual status (the coefficient that determines a leader's actual term in office 
compared to the term stipulated by law -called the TOR-index) allows for understanding political and economic factors of the weak theoretically predictable connection between the index and inflation better; and

e) The proximity of the relationship may be sufficiently sensitive to the nature of the index specification that is a reflection of more complex social interactions between public choices, governmental institutions, and the central bank.

Further investigations, which can be considered furtherances of the first generation of explorations, pay special attention to the following matters.

First, standardization of CBI components and distinguishing the "best practices" (Lybeck, 1998) takes place in a more systemrelated context than the exceptional contrast of political and economic independence, as it has been shown in the famous work of Debelle and Fischer (1994). At the same time, panoramic investigations fall outside the scopefor application of the currently canonical GMT-index (GMT - from Grilli, Masciando, Tabellini (Grilli et al., 1991) (see Cukierman, 2008; Siklos, 2002; and Kozyuk, 2004).

Second, cases of developed countries' proximity of the relationship between the independence index and inflation may seem to be weak due to a reduction of a group variation of inflation. Thus, when inflation becomes more globally-centric, the role of monetary authorities' status may be significantly diminished. For instance, so-called global disinflation and acknowledgement of a lower inflation level is more optimal in time of a higher level of openness (review and analysis of this problem is represented in Koziuk (2009)) may decrease the inflation level regardless of changes in the formal status directly or by changing the driving factors of policy that need not be approved by legislation. Some researchers argue that standard regression models analyzing relationship between the inflation level and the independence index do not always work. Quintile regressions are more efficient, but even they do not always give results adequate for interpretation. The main reason for this is an essential difference in the nature of distribution of inflation in the world and the nature of distribution of the index, which is measured monetary autonomy (Siklos, 2008).

Third, changes in the status of central banks is a component of broader structural reforms related to the search for institutional variants for adaptation to a more aggressive global competitive environment or to the imperfections of global capital markets. It is not a coincidence that detecting changes in the status of a regional perspective does not cast doubts that increases of the level of CBI (both political and economic) is a global trend (Jacome, 2001; Jacome et al., 2005; Arnone et al., 2006, 2007).

Fourth, the global financial crisis increased strain over the matter of independence of monetary authorities in light of the format of unconventional monetary policy realization, "fiscal domination," and the appearance of the new phenomena of "financial domination" and "domination of expectations". Despite the fact that no formal changes in the direction of reducing the level of CBI coexists with actual consent for a more accommodative policy, the debate on allotment of monetary authorities' powers to apply macroprudential tools nevertheless may be seen as the preservation the concept of monetary authorities' autonomy (Koziuk, 2015; Jacome and Mancini-Griffoli, 2014). In light of post-crisis changes in the status of monetary authorities, there is a well-defined tendency of a rise in independence and strengthening transparency. Additionally, the latter has especially increased in developed countries alongside independence in emerging market countries (Dincer and Eichengreen, 2014).

Nevertheless, uneven progress in the achievement of price and financial stability, coupled with the existence of significant asymmetries not only in the formal status of central banks, as in the political and institutional imprints of actual positioning of monetary policy in coordinates of macroeconomic choice, intensified research that can be characterized as the second generation. A common feature of investigations of this type is a search for drivers of change in the level of $\mathrm{CBI}$ and their institutional content. This approach is worth considering as extremely fruitful, because it falls outside the framework of the conventional contrast of the proximity of the relationship of the independence index and inflation in terms of developed countries and the rest of the world.

Consequently, in a series of investigations, a significant progress in the increase of independence and transparency level of monetary authorities and the preservation of an inverse relationship between appropriate indices and the inflation level is confirmed. Thus, a combination of indices and a comparison of their representativeness are followed by a search for new factors to fill in CBI with a particular sense. For example, the GMT-index appears simplified (although it remains universal, it is computed for the largest number of central banks (Arnone et al., 2007) compared to the extended CWN-index (Cukermann, Webb, Neyapti), or compared to the index of Dincer and Eichengreen (2014), who rely upon a more radical approach to understanding which factors make a central bank more independent in political, economic, and financial spheres.

As for drivers increasing the independence level of monetary authorities, there is no established position. For instance, proceeding from the CWN-index value for 99 countries, Crowe and Meade (2008) conclude that the rise monetary authorities' 
independence inversely corresponds to the level already reached (i.e. the higher is initial level, the smaller its future increment), but corresponds positively with the currency exchange rate regime (a choice in favor of a fixed currency exchange rate stimulates choosing a more independent central bank, because it helps to restrict political pressure on monetary decisions inconsistent with target level of the exchange rate) and the democracy level (democratic societies tend to build more transparent institutions and the level of the latter correlates to the level of monetary autonomy and also in such societies there is a high tolerance level to a system of checks and balances). In its turn, a rise in independence positively affects the quality of state institutions, exchange rate flexibility, and transparency. The first is very important, because a more independent central bank prevents mild budget restrictions and pushes a choice in favor of higher quality institutions, otherwise the economy would be at risk of permanent instability and capital outflow. Dincer and Eichengreen (2014), using89 central banks as an example, chose independent variables affecting the dependent variable - central bank independence index (CWN-index and the authors' own index), past inflation, transparency level, financial depth, GDP per capita, sizes of indebtedness from IMF funds, and the quality of institutions (a set of variables following World Bank Government Efficiency Indicators). They concluded that past inflation, cooperation with the IMF, and less developed financial markets have the largest influence on the rise of monetary autonomy in countries with medium and low incomes. Thus, the transparency level and past inflation are the most significant factors influencing independence in the whole selection. Additionally, they confirm that the level of the latter traditionally corresponds inversely to the inflation level and its variability.

Romelli's (2015) attitude to drivers of strengthening of monetary autonomy is more skeptical. He offers a dynamic index of $\mathrm{CBI}$ for 50 countries for the period from $1972-2014$, due to which he shows that the rise of CBI is more probable where "external pressure" has taken place: cooperation with IMF or demands of membership in a currency union. Koziuk $(2005,2009)$ demonstrates that benefits of membership in an integrated union may destroy a coalition resisting the strengthening of monetary autonomy, as a result of which formation of currency unions is a powerful driver of the latter. In other words, macroeconomic and institutional benefits from a rise in $\mathrm{CBI}$ are not always obvious in countries where sufficient public pressure for reforms falls short due to the complicated system of hidden benefits from monetary policy manipulation.

Berggren et al. (2011) pays attention to the connection between increased independence of monetary authorities and social trust. Using neo-institutional approaches to explain social conflicts and expenditures for negotiations, they confirm that structural reforms of monetary policy are not realized exceptionally in the need for them. They are the consequence of consent for their realization and how social trust among participants of political markets allows changes in essence without the review of legislation, which could be regarded as transformation of central banks on a formal level. As the level of social trust is an attributive characteristic of the type of society, it is not necessary to expect that the status of the central bank should be homogeneous in societies of different types. This conclusion is of large importance for analysis of commodity economies, in which possibilities for rent-seeking cause the appearance of a potential level of opposition among social actors that is inconsistent with the trust among them. On the other hand, a similar conclusion allows for understanding why particular central banks are more successful in price stability support even with a lower independence level compared to those having larger autonomy.

Building on the topic of institutional differences between countries, Bodea and Hicks (2012) point to necessity to explain less successful experiences of struggles with inflation in developing countries, not so much by problems related to the nature of estimating the level of independence (calculation methods and structures of indices are often criticized), but by the actual actions of monetary authorities. Their investigation covered 81 countries since 1973 . Differences in the growth rate of the M2 aggregate were analyzed in light of the effects of discipline (less money minting even with such possibilities available), trust (public expectations for successful operation of central bank), and with different types of rulership. In democratic regimes, a more conservative central bank is more likely to exist (it is expressed through a lower volume of the money supply's growth rate) due to a system of checks and balances and the possibility to freely criticize the ruling government. At the same time, except for effect of discipline, the central bank, trust to which is provided by configuration of democratic political institutions, will tend to create pre-conditions for stable money demand, lowering inflation expectations.

Nevertheless, Bodea and Hicks (2012) offer more optimistic view on the role of democracy in the provision of CBI that theoretically does not always harmonize with analogous analysis of fiscal policy, in which government fragmentation, polarization of budget coalition participants' interests, attempts "to restrict the successor," etc., significantly deviate the budget deficit from the optimal one. In extrapolating the status of monetary authorities, it is obvious in light of opposite conclusions in the series of empirical investigations.

For instance, Lucotte (2009) concludes that the level of CBI increase in countries with average and low incomes for the period of 1995-2004 has significantly promoted the strengthening of fiscal discipline effect, because governments have lost an easy access to seigniorage. Consequently, the status of monetary authorities has a positive influence on fiscal policy design. Contrary to this conclusion, Heimonen and Maslowska-Jokinen (2014) assert that positive results of increased CBI in the budget deficit sphere are not perceptible. Contrarily, if the fundamental precondition of the budget deficit - low-quality institutions - has 
not been settled, reinforcement of the autonomous status of the central bank causes growth of the national debt. The same refers to the private sector. Extending possibilities to take loans, for instance, owing to the positive effect of monetary discipline ( $C B I$ reduces inflation followed by a fall in interest rates) results in the rise of the level of indebtedness in the spheres where appropriate institutional preconditions for more restrained economic behavior are missing, which is proven by data from 14 EU member countries. Consequently, one may state that the nature of institutional configuration of a particular society can assimilate the $\mathrm{CBI}$ principle rather divergently. On the other hand, emphasis on the institutional differences of commodity economies requires appropriate analysis on the example of central banks.

\section{Monetary autonomy in commodity countries}

Although the majority of research on macropolitical specificity in commodity economies is not dedicated to the status of central bank, consideration of such specificity is important. It will assist in understanding the logical formulation of macropolitical priorities as a precondition of socio-political motivation for a level of independence for monetary authorities. As commodity wealth provokes a large variety of "redistribution temptations," traditional analysis of macroregulators in commodity economies is concentrated upon fiscal policy (for instance, Aliyev, 2013). However, the realization of monetary policy in commodity-exporting countries is subject to a "specialized" analytical view, which in Frankel's (2010) opinion, is conditioned by the problem of procyclicality. Conventional targeting of inflation or different kinds of currency exchange rate fixation can't neutralize the aspect of the procyclicality of commodity economies, which is structurally specified by large shocks caused by terms of trade and reverses in capital flows. Frankel et al. (2008) and Frankel (2010) offer shift the focus on targeting manufacturers' prices, but not CPI. Also, these investigations of monetary policy are not dedicated to the role of the status of the central bank. The question of a correlation method for CBI and targeting manufacturers' prices is not raised, as it requires a skeptical attitude under the effect of price stability as the purpose of policy and mandate being criterial in formulation and provision of monetary authorities.

Ignoring the issue of $\mathrm{CBI}$ when considering an optimal monetary regime for commodity economies looks like a way toignore the fact that the objective macropolitical function in such countries may vary as follows: developmentalism and an activist structure may be combined with welfare redistribution among separate groups. The currency exchange rate has a specific position in this context. On one hand, lively discussions on the problem of the relationship between real appreciation and the "resource curse" and the exchange rate as a welfare redistribution tool are held around selection of optimal regime of the currency exchange rate for resource-rich countries. The influence of the currency exchange rate regime on selection of a status for the central bank in resource-rich countries is not being discussed.

This problem can be regarded from two sides. A more independent central bank focuses on achievement of price stability, due to which a more flexible exchange rate is provided. Regime dependent central banks support fixed exchange rates and monetary autonomy is required to mitigate pressure on policies inconsistent with a fixed exchange rate regime. In the case of commodity economies, investigators mostly pay attention to the selection of the currency exchange rate regime, within which framing the status of the central bank is one of the explanatory variables. Empirical investigations prove that the more a particular country depends on resource exports, the more probable its government will choose a fixed rate. However, there are some differences. Aliyev (2014) confirms this on the basis of 145 countries from 1975-2004. The researcher simultaneously underlines that the larger the number of high-quality institutions, the more independent the central bank, and the less procyclical fiscal policy are in a country, the more probable its government will choose a more flexible exchange rate regime. In this research, special attention is paid to the important role of $\mathrm{CBI}$ as a precondition for choosing a more flexible exchange rate, corresponding to previous investigations on the positive relationship between the quality of national institutions and a selection in favor of larger monetary autonomy. But this investigation does not contain information about the relationship between commodity wealth and a selection in favor of the status of the central bank either in the context of choosing an exchange rate regime or otherwise.

In contradiction to this opinion, Wills and van der Ploeg (2014) state that accumulation of reserves is the simplest method of creating a quasi-sovereign wealth fund that additionally guarantees support of the fixed exchange rate, without which this fund could have been liquidated. If the central bank delegates creation of such a fund and its protection through a fixed rate, in which a method of macroeconomic stability support is focused, this is the consequence of understanding the risk that if this fund had been established by the government, it could have become the target of a raider attack or could have been spent by a clan-political group. Often it is impossible to create such a fund at all because of political corruption, which spends excessive costs using formal democratic institutions, provided that it does not matter whether they are current or investment ones. Wills and van der Ploeg (2014) do not argue over the relationship between commodity wealth and 
the status of the central bank, but demonstrate the problems with creation of sovereign wealth in Nigeria, its spending in Ghana, and raiding in Nauru. Thus, in this context a central bank should be less independent to protect a fixed rate through formation of a sovereign wealth fund that goes outside the standard theory to the contrary of Aliyev (2014) results is more in accordance with the traditional view of the problem. This more traditional vision was formulated by Obstfeld (2000) on the basis of discussions after the Asian crisis: macroeconomic stability is better achieved due to CBI than due to a fixed exchange rate. But it does not disprove the hypothesis that specific institutional framework conditions in resource-rich countries and the specific targets of macropolicy in them do not include a political choice in favor of a less independent central bank. Therefore, such a choice should not be based upon the currency exchange rate regime or level of national indebtedness (which are often considered in analysis of delegation of one or another level of autonomy by central banks in emerging market countries), if it is conditioned by deeper institutional factors.

\section{Opting for less independent central banks in commodity economies: theoretical reasoning and tendencies for reform of monetary authorities}

\section{Political economy of the functional choice concerning more dependent central banks}

Explaining a lower level of monetary authorities' independence in resource-rich countries requires further consideration of the range of issues that are discussed in the theoretical analysis of the problem. Methodologically, they have to rely on peculiarities of the institutional structure of commodity exporters and specific monetary problems, namely the choice of an exchange rate regime, the management of currency reserves, etc. Corden (1982) is one of the first who shows that: both a floating exchange rate and actual appreciation of a fixed exchange rate pose a threat to suppression of industrial exports ("Dutch disease"). The objective function of the central bank in commodity economies should be adjusted for structural priorities. Due to the fact that a fixed exchange rate combined with optimal intertemporal policy allows reducing the variation in GDP and inflation, exchange reserves and fiscal buffers (which later turned into sovereign wealth funds) begin to be treated as a part of the policy of "foreseeing savings." Also, it is necessary to take into account that overcoming resource dependency requires a special structural policy that may allow the existence of a more controlled central bank, whose monetary choices would comply with a long-term strategy of the government concerning prioritizing variations of inflation or the exchange rate. For example, Hausmann and Rigobon (2002) state that the interventionist structural policy in trade and finance better corresponds to the logic of the fight against the "resource curse" than a policy based solely on compliance with intertemporal savings and the rise of allocational efficiency in financial markets.

The other side of the problem is the institutional deformity of "rent-seeking." In most cases, it is stated that they cause procyclicality of the fiscal policy (Aliyev, 2012). However, under the procyclicality of the fiscal policy in resource-rich countries lies a so-called "predatory government," "voracity effect," or open social conflicts related to control over resources and a lack of guarantees for ownerships (Auty, 2001; Arezki and Bruckner, 2010). Hence, the issue of transitory or persistence of a price shock in the commodity market, which is important for optimal policy of intertemporal savings, is ignored in the environment of weak institutions. Moreover, the transition from variable positive shocks to a steadily rising price trend only escalates the struggle for resources and exacerbates the problem of wasteful consumption.

Without going into a discussion about the optimal policy for a commodities-dependent economy, it should be noted that, within the analytical framework of the number of macroeconomic and institutional effects (which are shown in Table 1) of commodities exporters, one can see the explanation as to why the central bank appears to be less independent than in other cases. In this context, in this manner assumptions are made about whether this institutional design of the monetary policy is more or less optimal. Table 1 generalizes a set of macroeconomic and institutional effects and peculiarities of commodity economies, in terms of which the role of a less independent central bank is analytically outlined. 


\section{Table 1. Structural peculiarities of commodity economies and central banks independence: positive analysis}

\section{Commodity economies: effects and peculiari- ties}

Political and economic costly tax collection and debt financing; Is the result of institutional weaknesses of the government in the fiscal sphere

Political and economic costly tax collection and seigniorage is the result of institutional fragmentation that prevents even distribution of the tax burden, or when the taxable commodity sector is "privatized" by influence groups

"Resource curse" and prevention from the "Dutch disease." The inflow of large amounts of FX increases the real exchange rate, which replaces the non-commodity sector and encourages the development of a domestic services sector with a high marginal propensity to consume; Structural policy is based on the elimination of preconditions of real revaluation of the rate and allows direct support to non-commodity sectors

Currency reserves serve as a quasi- sovereign wealth fund; Increases in these reserves requires an appropriate exchange rate policy, and management of such a fund may require special financial control

\section{Choice in favor of lower CBI}

Foreseeing increases of currency reserves guarantees independent financial solvency and can reduce the cost of external borrowing; Forcing the central bank is associated with keeping the rate up and accumulation of large reserves

The macroeconomic instability of a fragmented government limits its ability to implement external borrowing due to political risks, which make foreseeing increases in reserves hardly probable, and instead of this they encourage seigniorage; Fiscal dominance is prevalent; When the central bank is a tool to "limit the next government" because of inflation and financial instability, none of the groups is interested in increasing its independence. The same applies to access to seigniorage

Structural limitations for real revaluation may require an appropriate institutional decision concerning the central bank, especially when capital inflow is powerful and persistent and, due to this, domestic price stability may be doubtful; The dominance of the central bank concerning the priority of exchange rate stability, but not price stability, is accompanied by fiscal dominance in accordance with the priorities of industrial policy

Pressure on the central bank may address the issue prioritizing the exchange rate, which would be consistent with the maximization of foreign assets in the long run. Also, there is the problem of control of financial and investment risks of external assets management. $\mathrm{CBI}$ may complicate the control over quality aspects of external assets management since management objectives may not always be based on economic criteria

\section{Potential optimality}

The choice in favor of lower independence is not optimal because it does not solve the fundamental problem of the weakness of fiscal institutions

The same as above

Pressure on the priority of exchange rate stability over price stability does not always guarantee salvation from the problem of "Dutch disease" without additional measures being taken in the sphere of fiscal policy and regulation of wages; This choice has a fair optimality only when combined with the liability of the government for non-inflationary expense policies; The participation of the central bank in the active industrial policy is not optimal because it destroys incentives to develop non-commodity exports through the effects of inflation and weakening of sensitivity to competition

This situation shows the problems of institutional design of the control over external assets management; It can also be a sign of political failure to divide foreign assets into monetary (currency reserves) and sovereign (sovereign wealth fund), as a result of which a lower $\mathrm{CBI}$ may be justified only by problems related to effective control 
"Predatory government" and increase ("defense") of reserves; The government which maximizes the use of limited political and economic group faces a problem of access to external markets of borrowings. The necessary increase in reserves that is needed for this purpose can be considered as a macroeconomical step towards a creation of a monetary basis for the fiscal expansion. Although, this is a situation that is peculiar to countries with weak institutions in general, a commodity economies may be characterized by a combination of excessive costs with the reduction of external revenues, or expectations of such reduction

"Predatory government" and reduction of reserves; The maximization of consumption by one political and economic group takes place due to the support of a fixed exchange rate in the conditions of the expected reduction in revenues; Also, the reduction in reserves is a way to limit future governments or a means to extend the "expropriation" of value for the foreign assets already accumulated

"Voracity effect" is a radical case of the "predatory government" which increases expenditures faster than world prices rise and the conditions of trade improve; It takes place in conditions of expected and persistent increases in prices for commodities, during which the expropriation of value progresses on a scale that results in the loss of motivation for economic activity by agents outside the ruling group; Expansion of expenditures reduces reserves and increases external debt

Foreign exchange and rate estimation of rent; The estimation of rent in foreign currency and the source of its formation may have influence on the choice of exchange rate policies with corresponding consequences for the money supply and reserves. When the main source of rent is foreign revenues, then the interest in choosing the rate (or in a broader sense in choosing the instrument of economic policy) grows, this stimulates exporters regardless of the general equilibrium of economics; When the main source of rent is internal expropriation, the support of a stable exchange rate may reflect efforts to increase the cost of domestic revenues in foreign currency, encouraging the expansion of opportunities for exporting capital
Pressure on the central bank may lie in creation of monetary conditions for accumulation of reserves that are not socially optimal. The increase in reserves intended for consumption by one group takes place at the cost of a reduction in consumption by the rest of the society; Retention of the rate from the equilibrium movement towards PPP is one of the examples of this; Similarly, a more rigid internal monetary policy may reflect circumstances of "reserves protection," when the main negative factor on the balance of payments is a "privatized" fiscal policy

A dependent central bank prefers the support of a non-equilibrium rate to the deterioration in balance of payments, which makes its reserves decrease and imbalances grow; Areduction in reserves may also occur through direct or indirect access to the limited supply of currency by specific members of the ruling group; Monetary policy becomes a redistributive tool that rationalizes access to $\mathrm{FX}$ in favor of particular persons

Under the "voracity effect," monetary preconditions of intertemporal savings are removed institutionally, and due to this fact the expectations of stable and growing external revenues are accompanied by the accumulation of net external liabilities and deceleration of economic activity; Pressure on the central bank occurs in the directions of the elimination of reserve accumulation, support of a nonequilibrium rate, enabling the export of capital, and impeding access of other economic agents to FX

The central bank becomes an institutional form for redistributive use of the exchange rate and capital flows regulation; Supporting exporters does not always guarantee an increase in reserves through export of the capital; Second, the export of capital becomes an external continuation of the internal expropriation (raid) and the dependent central bank is required to allow access to FX and to bypass formal restrictions on the movement of capital
The combination of an excessively rigid monetary policy and obviously expansionary fiscal policy would not be evidence of the optimality of a more dependent central bank; Such a mixed policy may be implemented during a relatively indefinite period of time, the duration of which is affected by factors of the external market environment or factors of internal political stability; The lack of $\mathrm{CBI}$, which leads to an imbalance of the structure of aggregate expenditures, ends with a crisis

The support of the non-equilibrium rate and loss in reserves from the point of view of redistributive considerations may not be evidence of the optimal choice in favor of a dependent central bank

This is the most blatant instance of a non-optimal institutional design for macroeconomic policy. The lack of $\mathrm{CBI}$ is not only a counter-weight to fiscal expansion, but it is also a monetary continuation with explicit redistributive focus ending in procyclicality that borders with a permanent crisis

Such a choice is not optimal, as it involves the redistributive nature of foreign exchange rate policy, and decisionson regulation and supervision of capital flows turn into an instance of a "privatized" institute 
At the same time, the peculiarities of commodity economies in terms of the functional approach to CBI allow a potential optimality of a lower level of monetary autonomy, but they do not determine it unconditionally. This means that there may be circumstances in which the wealth of resources is considered as a source of a "resource curse" threat. In other words there may be a socio-political acknowledged fact (regardless of the political regime) for the necessity to combat resource dependence. Preventing the "resource curse" may become a public choice and not be the subject of a social compromise or grounds for opportunistic behavior. In such cases, a more dependent central bank is not a definite optimal choice, as traditional monetary autonomy does not exclude a better macroeconomic result and does not contradict the possibilities of implementing structural policies for diversification and intertemporal smoothing. Past inflation experience as a determinant for reforming the status of the central bank may also be independent from the level of resource wealth, but when the latter became the reason for a policy that ended in the acceleration of inflation (e.g., Venezuela), the choice in favor of a higher level of CBI may be considered in the traditional macroeconomic context and not in the light of overcoming resource curse limitations.

\section{The ruling trend of reforms of central banks}

In light of the fact that the status of the central bank is not an institutional invariant both in terms of lower and higher $\mathrm{CBI}$, the problem of reforms in monetary authorities remains a relevant comparative backdrop in the case analysis of resource exporters. The issue of such reforms is even more vital if we take into account at least two trends.

First, fluctuations in prices and capital flows become increasingly synchronized with the phases of global liquidity behavior, resulting in major changes in the inflow and outflow of foreign exchange cover of more sectors of the economy and finance. Now the problem of procyclicality of commodity economies mostly concerns financial stability and financial imbalances. Namely synchronization of the movement of world prices for resources and assets with the vector of capital movement is not just deepening the conflict in terms of the stability of prices and exchange rate, but adds a financial dimension to it: a series of external borrowings of the private sector, a disproportion of foreign currency assets structure and liabilities in the real and financial sectors, an increase of external assets alongside a worsening of the balance of payments, a real estate bubble, excessive household sector leverage, etc.

Second, due to social capitalization of the resource wealth, a trend to deepen the internal market is being formed. As a result, a range of influences on inflation is expanded and the behavior of the aggregate demand in certain periods of the cycle of global prices for commodities deviates from the tough conditionality of the world market. Thus, a more traditional relationship between price stability and aggregate demand is activated, and, due to this, structural changes activate the preconditions for a more representative modality of links between macroeconomic processes and the institutional format of the monetary policy. Integration between $\mathrm{CBI}$ and inflation becomes particularly important where marginal cases of resource wealth are not observed, and in these cases the extent of fluctuations of global liquidity will potentially demand institutional adaptation, signs of which will be formed by a trend of structural reforms in the monetary policy for the last period.

The reforms of central banks clearly indicate that the increase of political and economic independence is an unambiguous fact, which finds its confirmation in the change of value of the relevant indices. As such, Arnone et al. (2007) confirm that the increase of both political and economic independence of monetary authorities goes in the same direction, although with certain peculiarities for different world regions and groups of countries. In particular, visible progress in improving economic independence is indicative for countries with emerging markets and developing countries (see Table 2).

\section{Table 2. Regional trends of increasing CBI. GMT-index for 163 countries}

\begin{tabular}{|c|c|c|c|c|c|c|c|}
\hline & \multicolumn{3}{|c|}{ Political } & \multicolumn{3}{c|}{ Economic } & \multicolumn{2}{c|}{ Total } \\
\hline & $1980 s$ & $2000 s$ & $1980 s$ & $2000 s$ & $1980 s$ & $2000 s$ \\
\hline Africa & 0.17 & 0.37 & 0.52 & 0.72 & 0.33 & 0.53 \\
\hline Asia and Oceania & 0.21 & 0.54 & 0.41 & 0.73 & 0.30 & 0.63 \\
\hline Europe & 0.32 & 0.79 & 0.27 & 0.98 & 0.30 & 0.88 \\
\hline Middle East & 0.25 & 0.40 & 0.36 & 0.68 & 0.30 & 0.53 \\
\hline Latin America & 0.36 & 0.50 & 0.36 & 0.88 & 0.36 & 0.067 \\
\hline In total & 0.28 & 0.56 & 0.38 & 0.84 & 0.32 & 0.68 \\
\hline
\end{tabular}

Source: Arnonen et al. (2007). 
Application of a gradual, non-formal (index growth) approach to the evaluation of trends in the sphere of CBI also reflects its significant strengthening as a result of implementing corresponding reforms. Remarkably, the distribution of reforms overtime is tightly correlated enough with periods after crises. On the basis of the data provided by Romelli (2015), peculiar "storms" of reforms since 1972 may be observed. The reforms of the late 1970s-1980s are definitely related to the effects of high inflation in developed countries. The reforms of the early 1990s are related to the process of European integration. From 1997 to 2002 , a modernization of central banks in countries with emerging markets was the response to the Asian crisis and the search for institutional alternatives to inflexible rates. Since 2007, one may observe a continuation of institutional adaption to post-crisis instability, when the independence of monetary authorities continues to be considered as an important element of adaptation to a new macro-financial environment. In the words of $\mathrm{CBI}$ indices, reforms also confirm the unambiguity of the trend concerning strengthening of the institutional protection of monetary authorities (Table 3). It is important to emphasize that a starting level of the average, minimum, and maximum values of the relevant indices for the corresponding group of countries increase with each subsequent period.

\section{Table 3. Indices of $\mathrm{CBI}$ in terms of periods and number of reforms}

\begin{tabular}{|c|c|c|c|c|c|c|}
\hline \multicolumn{2}{|c|}{ Years } & 1972-1979 & 1980-1989 & 1990-1999 & 2000-2009 & 2010-2014 \\
\hline \multicolumn{2}{|c|}{ Number of countries } & 28 & 30 & 49 & 50 & 50 \\
\hline \multirow[t]{4}{*}{ ECBI } & $\begin{array}{c}\text { Number of } \\
\text { reforms }\end{array}$ & $8(3 ; 5)$ & $9(2 ; 7)$ & $42(3 ; 39)$ & $31(2 ; 29)$ & $11(5 ; 6)$ \\
\hline & Average Value & 0.490 & 0.503 & 0.594 & 0.755 & 0.777 \\
\hline & Minimum & 0.201 & 0.206 & 0.206 & 0.387 & 0.399 \\
\hline & Maximum & 0.783 & 0.783 & 0.963 & 0.963 & 0.963 \\
\hline \multirow[t]{4}{*}{ GMT } & $\begin{array}{l}\text { Number of } \\
\text { reforms }\end{array}$ & $6(3 ; 3)$ & $6(2 ; 4)$ & $37(3 ; 34)$ & $26(2 ; 24)$ & $8(4 ; 4)$ \\
\hline & Average Value & 0.401 & 0.411 & 0.528 & 0.720 & 0.744 \\
\hline & Minimum & 0.063 & 0.063 & 0.063 & 0.125 & 0.125 \\
\hline & Maximum & 0.750 & 0.750 & 1 & 1 & 1 \\
\hline \multirow[t]{4}{*}{ CWN } & $\begin{array}{c}\text { Number o } \\
\text { reforms }\end{array}$ & $8(2 ; 6)$ & $7(0 ; 7)$ & $37(2 ; 35)$ & $24(1 ; 23)$ & $5(0 ; 5)$ \\
\hline & Average Value & 0.390 & 0.412 & 0.533 & 0.746 & 0.774 \\
\hline & Minimum & 0.090 & 0.135 & 0.135 & 0.193 & 0.193 \\
\hline & Maximum & 0.735 & 0.799 & 0.979 & 0.979 & 0.979 \\
\hline
\end{tabular}

Note 1. ECBI stands for Romelli's dynamic CBI index. GMT stands for the index by Grilli, Masciandaro, and Tabellini. CWN stands for the index by Cukierman, Webb, Neyapti.

Note 2. Explanation to the column "Number of reforms": total number of reforms (number of reforms that reduce the index value).

Source: Romelli (2015).

The most significant in this regard is the period of the 1990s. During this period, the most considerable increase of CBI took place and the empirical basis for "best practices" that later gained wide recognition were formed. A slightly slower rise of the independence level at a later stage gives evidence of a relatively high level already achieved that is also noted by other authors (see Dincer and Eichengreen, 2014), but this does not rule out that the ongoing monetary reforms have another quality - they are more focused on the "nuances" of institutional relationships with the branches of government, the appointment system, and the political responsibility of leadership. As a matter of fact, these are the components of independence that may be easily frustrated within the framework of political resistance to the declaration of its principle as a fundamental institutional practice, which is peculiar for countries with weak institutes. If the principal assumes a deviation from the socially optimal rate of inflation or obtains hidden (or obvious) benefits from quasi-fiscal operations, or if he is directly involved in fiscal dominance, then an agent, whatever status he has, has little chances for behavior that differs from the principal's. It is no coincidence that the quality of institutes was especially moved out to the fore when the drivers of the increase of the level of CBI were determined in studies of the second generation (Crowe and Meade, 2008; Dincerand Eichengreen, 2014). 
As for a certain increase in the number of reforms during 2010-2014, as a result of which the index of independence goes down (see Table 3), they should not be connected with the direct rethinking of the paradigm of the autonomy of monetary authorities after the global financial crisis, discussions of which have taken place (Koziuk, 2015), but with the transformation of functions and responsibilities of central banks in banking supervision. Differences in the structure of indices listed in Table 3 clearly show this. The CWN-index is more complex and sophisticated, and it includes a wider range of items of monetary autonomy compared to the GMT-index. But the latter is more sensitive to powers in the sphere of banking supervision (according to the GMT approach: the greater the responsibility entrusted to the central bank in this sphere, the less independent it is). A similar situation occurs with the ECBI-index. Changes in financial regulation and strengthening of monetary responsibility for financial stability took place in some countries, a perfect example of which is the Bank of England. Accordingly, the increased number of reforms that reduce $\mathrm{CBI}$ is a matter of banking supervision, which captures the GMT-index and ignores the CWNindex rather than a matter of institutional principles of the monetary policy.

\section{Resources export and CBI}

\section{Commodities export and independence of monetary authorities: a comparative analysis in terms of groups of countries}

For checking the hypothesis a lower level of CBI in commodity economies, it a group comparison was held of an extended CWN-index magnitude, GMT-index, and central bank transparency index in the context of developed countries (the first group), countries with emerging markets, developing countries (the second group) and resource-rich countries (the third group). As mentioned above, the first two indices differ on a compositional level. They are counted up for the different periods of time and cover a different number of countries, which in some cases mismatch. On one hand, the same groups that are evaluated on the basis of the average values of different indices, having a slightly different composition, cannot be compared directly. On the other hand, the differentiation of the groups' compositions in the context of available index values allows testing of the commonality of trends in cases when the indices' average group values have identical patterns. In other words, the distinctive content of groups and the indices' composition can be used as independent confirmation of the hypothesis and mutual reinforcement of arguments based on a separate analysis in the context of different indexes.

The theoretical hypothesis is the following: if the resource factor really makes an impact on the choice of the level of CBI, the average value of the applicable index of the third group of countries should be lower than the first two. It is especially important that the average value of the third group is lower than in the second, represented by countries with low and medium incomes, similar to most commodities for a wide range of institutional and structural indicators and which account the largest number of central banks' reforms in the recent past. The results in the Tables 4-6 fully confirm to the suggested hypothesis

\section{Table 4. GMT-index in the context of groups of countries}

\begin{tabular}{|c|c|c|}
\hline & $1980 \mathrm{~s}$ & 2000 \\
\hline Developed countries & 0.48 (18 countries) & 0.75 ( 27 countries) \\
\hline $\begin{array}{l}\text { Countries with emerging markets and developing } \\
\text { countries }\end{array}$ & 0.34 (57 countries) & 0.24 (135 countries) \\
\hline Commodities exporting countries & 0.34 (17 countries) & 0.55 (44 countries) \\
\hline $\begin{array}{l}\text { Commodities "extra exporting countries", a share of } \\
\text { commodities export is more than the median value } \\
\text { in } 65 \%\end{array}$ & 0.27 (9 countries) & 0.49 ( 28 countries) \\
\hline $\begin{array}{l}\text { Energy resources "extra exporting countries", the } \\
\text { share of commodities export is more than } \\
\text { the median value in } 35 \%\end{array}$ & 0.24 ( 3 countries) & 0.47 (22 countries) \\
\hline $\begin{array}{l}\text { Metals "extra exporting countries", the share of } \\
\text { commodities export is more than the median value } \\
\text { in } 12 \%\end{array}$ & 0.27 (4 countries) & 0.62 (11 countries) \\
\hline $\begin{array}{l}\text { Food resources "extra exporting countries", the } \\
\text { share of commodities export is more than } \\
\text { the median value in } 15 \%\end{array}$ & 0.40 (9 countries) & 0.59 (15 countries) \\
\hline
\end{tabular}

Note 1. Arranged into groups by the author on the basis of a commodities-exporting countries list and the empirical bases of the IMF's "extraexporters" definition (2015). The GMT-index is contained in the Arnone et al. (2007). 
Thus, the data in Table 4 allows emphasizing a few important points. First, the level of $C B I$ in the world has advanced unambiguously. Herewith the resource-rich countries are not an exception. On average, they tend towards the similar substantial increase of the corresponding assessing index value as for the second group of countries. In other words, the general trend of increasing monetary autonomy described above concerns the analyzed countries too. Second, the third group's independence level proved to be lower than the second group and significantly lower than the first, confirming the suggested hypothesis. Third, the formation of resource wealth has a significance. In energy resources exporting countries, the average value of the GMT-index turned out to be the lowest in the context of all these groups, meanwhile, in metals and food exporters, this value is sometimes higher than in the second group. Fourth, the increase of the GMT-index for the respective years in metals exporters is the highest, and in food exporters it has grown from the highest starting position. Fifth, it can be assumed that the formation of resources wealth has significant consequences. The rent value being derived from the resource type, in which the country is rich impacts the way in which the fight for access resources is institutionalized with the respective consequences for the monetary authorities' independence.

Table 5 illustrates the changes of an extended CWN-index from the end of the 1990s. The specificity is that, according to this index, the level of $\mathrm{CBI}$ in developed countries was lower than in other countries of the world. It can be explained by later reforms based on best practices. In addition, the group of developed countries is not made up of the EMU member countries which are presented in the ECB, whereas in Table 4 there is the country's representation of the GMT-index. Grouping in the context of "extra-exporters" was not conducted due to limited data. As for the suggested hypothesis about the lowest level of $\mathrm{CBI}$ in resource-rich countries, it has found confirmation here. The value of the corresponding index for the third group is lower than for the second one. Also, the value of this index for the second group has increased more significantly than for the third.

\section{Table 5. Extended CWN-index in the context of groups of countries}

\begin{tabular}{|l|c|c|c|}
\hline & 1998 & 2004 & 2010 \\
\hline $\begin{array}{l}\text { Developed countries } \\
\text { (12 countries + ECB) }\end{array}$ & 0.32 & 0.39 & 0.35 \\
\hline $\begin{array}{l}\text { Countries with emerging markets } \\
\text { and developing countries } \\
\text { (74 countries) }\end{array}$ & 0.47 & 0.53 & 0.54 \\
\hline $\begin{array}{l}\text { Commodities exporting countries } \\
\text { (22 countries) }\end{array}$ & 0.43 & 0.47 & 0.47 \\
\hline
\end{tabular}

Note 1. Arranged into groups by the author on the basis of the IMF'scommodities exporting countries list (2015). The extended CWN-index is contained in Dincer and Eichengreen (2014).

Table 6 shows the index change in transparency of central banks. Unlike the data of Table 5, the result is much closer to the case of the GMT-index. The transparency level of monetary authorities in developed countries is distinctively higher than in the rest of the world. For developed countries, the achievement of monetary efficiency occurs not only through formal independence, but also by increasing transparency. Central banks of resource-rich countries turned out to be the most opaque.

\section{Table 6. Transparency index in the context of groups of countries}

\begin{tabular}{|l|c|c|c|}
\hline & 1998 & 2004 & 2010 \\
\hline $\begin{array}{l}\text { Developed countries } \\
\text { (18 countries + ECB) }\end{array}$ & 6.78 & 9.13 & 10.53 \\
\hline $\begin{array}{l}\text { Countries with emerging markets } \\
\text { and developing countries } \\
\text { (100 countries) }\end{array}$ & 2.63 & 4.03 & 5.0 \\
\hline $\begin{array}{l}\text { Commodities exporting countries } \\
\text { (35 countries) }\end{array}$ & 2.35 & 3.55 & 4.32 \\
\hline
\end{tabular}

Note 1. Arranged into groups by the author on the basis of IMF's commodities exporting countries list (2015). The Transparency index is contained in Dincer and Eichengreen (2014). The maximum index value of transparency is 15. 
The lowest level of transparency of commodities-exporters' central banks can be considered in the context of the overall lower level of $\mathrm{CBI}$. This is the situation when low $\mathrm{CBI}$ and transparency reinforce each other, confirming the suggested hypothesis and represents itself in the reflection of institutional choice. It is possible to consider this problem also from the perspective of other structural characteristics of commodity economies. For example, taking into account the discovery in Dincer and Eichengreen (2014) stipulating an increase in transparency through the level of development and the depth of financial markets, the low openness and transparency of central banks in the third group of countries should not cause surprise if we take into account the results of Kurronen's investigation (2012). The low level of interior financial sector development in the group of countries analyzed can be qualified as one that reduces political and economic demand on central bank transparency, which has resulted in the value of the respective index. On the other hand, according to Wills and van der Ploeg (2014), the currency reserves in commodities exporting countries are a quasi-sovereign wealth fund, of which transparent management remains low. However, the low transparency of external assets management is the most probable for autocratic regimes or in the condition of weak institutions. It means that the link between the political regimes and resources wealth should also be taken into account.

For additional testing of the hypothesis about the conditionality of the level of CBI by a commodities factor, the TOR-index was applied (TOR-index from English - turnoverrate). According to Cukierman (1992) and Cukierman et al. (1992), it is intended to assess the correlation between the formal independence, which the index evaluates, and the actual one, which depends on how a central bank's management is over the whole statutorily-required period of engagement. The data in the Table 7 also does not contradict the given hypothesis.

\section{Table 7. TOR-index in the context of groups of countries}

\begin{tabular}{|c|c|c|}
\hline & Number of countries & Average index value \\
\hline Developed countries & 26 & 0.16 \\
\hline $\begin{array}{l}\text { Countries with emerging markets and } \\
\text { developing countries }\end{array}$ & 105 & 0.22 \\
\hline Commodities exporting countries & 37 & 0.28 \\
\hline
\end{tabular}

Note 1. Arranged into groups by the author on the basis of the IMF's commodities exporting countries list (2015). The index is calculated for 19702004. Dreher et al. (2007)

According to the data of Table 7, this index value is the highest only for resource-rich countries and the lowest for developed countries. However, the TOR-index is within the scope of critique. It will adequately describe the situation regarding the discrepancy between the formal and actual $\mathrm{CBI}$ only in the case when an appointed manager as the agent focuses on the lowest social optimal inflation level compared to the principal. In the categories of Rogoff (1985), this is a situation when the agent is more conservative than the principal, the consequence of which is that a more rigid monetary policy is not supported by the highest-level leaders by virtue of the electorate or other opportunistic considerations. In the case where the chief of the central bank does not meet the criterion of conservatism according to Rogoff (1985), the TOR-index value may not reflect a low level of actual independence: the principal is satisfied by a weak central bank chief without regard to the level of formal independence. In light of these considerations, the data presented in Table 7 requires cautious interpretation taking into account the resource-rich countries heterogeneity.

For example, according to Dreher et al. (2007) calculations, the central bank chiefs of the Persian Gulf countries occupied their positions the most stably, the countries of Latin America and other developed countries that changed chiefs the most commonly, occurred where inflation struggles were unsatisfactory or conflicting and inconsistent. If we take into account the nature of the political regime, you should assume that in autocratic countries the TOR-index will be lower because of the agent is tightly controled by the principal, whereas in democratic countries its low value will be the consequence of the fact that for the qualitative institutions, appointment and dismissal takes place on the basis of professional criteria. High values of the TOR-index will be in countries with weak institutions, primarily in commodity economies where the central bank is a tool or weapon for access to the rent of competing political and economic groups. In other words, the democracy level is sufficient for procedural possibilities of central bank managers' frequent changes, but the quality of democracy is low for appointing manager whose intentions in the field of monetary policy are not contrary to what policy that central bank would carry out with an appropriate independence level.

The relationship between the $\mathrm{CBI}$, the exchange rate regime, and the level of democracy reflects another aspect of the problem. Table 8 shows the distribution of commodities exporting countries according to monetary regimes, the terms of which are calculated with average group values of the GMT-index and the democracy index. 


\section{Table 8. Monetary regimes in resource-rich countries}

\begin{tabular}{|c|c|c|c|c|}
\hline Monetary regime & Peg to the US dollar & $\begin{array}{c}\text { Peg different from US } \\
\text { dollar }\end{array}$ & $\begin{array}{l}\text { Money supply } \\
\text { targeting }\end{array}$ & $\begin{array}{l}\text { Inflation } \\
\text { targeting }\end{array}$ \\
\hline Countries & $\begin{array}{l}\text { Iraq, Angola, Guyana, } \\
\text { Kazakhstan, Mongolia, } \\
\text { Saudi Arabia, Bolivia, } \\
\text { Mauritania, Timor-Lestre, } \\
\text { Surinam, Trinidad and } \\
\text { Tobago, Turkmenistan, } \\
\text { Venezuela, Vietnam, } \\
\text { Yemen, Ecuador, Bahrain, } \\
\text { Oman, the U.A.E., Qatar }\end{array}$ & $\begin{array}{l}\text { Cameroon, Chad, } \\
\text { Central African } \\
\text { Republic, Republic } \\
\text { of Congo, Equatorial } \\
\text { Guinea, Gabon, Mali, } \\
\text { Kuwait, Libya, Russia, } \\
\text { Syria, Botswana, Iran, } \\
\text { Azerbaijan, Algeria, } \\
\text { Brunei }\end{array}$ & $\begin{array}{c}\text { Guinea, Nigeria, } \\
\text { Papua New } \\
\text { Guinea, Sudan, } \\
\text { Zambia }\end{array}$ & $\begin{array}{c}\text { Indonesia, Peru, } \\
\text { Chile, Mexico, } \\
\text { Norway }\end{array}$ \\
\hline $\begin{array}{c}\text { The number of } \\
\text { countries }\end{array}$ & 20 & 16 & 5 & 5 \\
\hline $\begin{array}{c}\text { The commodity- } \\
\text { rich countries } \\
\text { share, } \%\end{array}$ & 43 & 32 & 11 & 11 \\
\hline $\begin{array}{l}\text { The countries } \\
\text { proportion, which } \\
\text { have made a } \\
\text { choice in favor } \\
\text { of this monetary } \\
\text { regime among all } \\
\text { countries, } \%\end{array}$ & 34 & 26 & 11 & 23 \\
\hline $\begin{array}{l}\text { Average GMT- } \\
\text { index }\end{array}$ & 0.54 & 0.46 & 0.49 & 0.70 \\
\hline Democracy index & 4.34 & 3.30 & 4.35 & 7.58 \\
\hline
\end{tabular}

Note: the democracy index value, reflecting the autocratic regime, 0-4; hybrid regime, accordingly, 4.1-5.94; 6.03-7.94 - weak democracy; more than 8.03 - full democracy.

Source: the countries distribution according to the monetary regime criterion in accordance with Wills and van der Ploeg (2014). The GMT-index is contained in Arnone et al (2007). The democracy index according to the Economist Intelligence Unit.

Based on the data of Table 8, we can come to the following conclusions. First, for the countries with fixed exchange rates and money supply targets, the average level of CBI is even lower than in the group of commodities exporters in general from Table 4. The independence level of the monetary authorities for inflation targeting regimes is comparable with the average level of developed countries. It confirms Aliyev (2014) research. In other words, the hypothesis that amore independent central bank is required to protect a fixed rate is not confirmed by the example of commodity economies. A higher level of monetary autonomy inherent for inflation-targeting regimes is evidence of the institutional maturity of such countries. Second, the fact of institutional maturity of commodity economies in terms of the monetary regime choice and the level of CBI is confirmed by the nature of the political regime. The countries, presented in Table 8 with fixed rate or money supply targets are mostly autocratic. And only inflation-targeting regimes have the level of democracy inherent for many developed countries. Third, the transition to inflation targeting and choosing autonomy for the monetary authorities in general is a reflection of a democratic institution's role in the neutralization of monetary policy's functional usage in the process of commodities rent redistribution. Fourth, in the context of specific and autocratic aspects of rents redistribution, a fixed rate appears better-integrated into external wealth control mechanisms, which needs a less transparent central bank. It makes the data of Table 6stand out. On the other hand, exchange rate stability could be considered as a component of autocracy's social contract with the society, where "stability" and prosperity (where it is based on the solvency ensured by the exchange rate stability) are the "loyalty retaliation" to the monopoly on the political power and resource rents. 


\section{Econometric evaluation of the relationship between monetary autonomy and commodity exports}

A regression analysis was used for additional hypothesis verification of the relationship between commodities wealth and the level of CBI. Despite the fact that resources wealth is not always measured by the share of commodity exports, specifically the primary extraction commodity exports (cultivation) or commodities with low added value, is considered as the most representative structural sign of the respective countries.

There are several approaches to define the criteria to assign countries as commodities exporters. The simplest approach was used at Aliyev (2013), where a resource-rich country is recognized by a share of commodity exports that exceeds $50 \%$ of the total export structure. An analogous variable of resource wealth appears in other investigations (Aliyev, 2012; Aliyev, 2013). The IMF makes use of a somewhat different approach. A resource-rich country means a country where the commodity exports share from 1962-2014 on average did not descend below 35\% of total exports and the net commodity exports for the same period of time exceeds $5 \%$ of the gross foreign trade (exports + imports) (IMF, 2015). For purposes of the countries list, these approaches are almost identical, but the latter is structurally stricter because it excludes those countries with significant intermediate consumption of commodities.

In empirical models, the commodities factor evaluation is often carried out as the example of a broad sample of countries without analytical groupings. It allows seeing the influence of the resources wealth variable that is mostly the commodity exports' share on the dependent variable in a wider range of structural characteristics. Similar work is research by Kurronen (2012) on the definition of features of commodity exports' impact on the financial sector structure (resources wealth inhibits banking sector development but encourages borrowing; the financial system market model is much more likely in commodity exporting countries; and the commodities sector does not require a significant internal financial sector, because it is based on eye-watering external borrowing to finance large-scale projects and the rent acts as the guarantee of solvency whereby the underdeveloped financial intermediation limits the access to finance in other sectors and aggravates the problem of the "resource curse"). In her regressive model, 133 countries were analyzed and the independent variable was the share of "mineral export," equivalent to the sum of the three positions of the World Development Indicators: the Structure of Merchandise Exports, namely: Agricultural Raw Materials + Fuels + Ores and Metals.

To determine the impact of the commodities factor on the level of $\mathrm{CBI}$, a sample of 150 countries were tested using a multifactorial regression type:

$$
Y=a+b 1 \times \ln X 1+b 2 \times \ln X 2+b 3 \times X 3,(1)
$$

where:

Y- the GMT-index. As mentioned above, this index was calculated for the greatest number of countries (Arnone et al., 2007). It sufficiently representatively estimates the formal status of monetary authorities, even though inferior to the breadth of coverage options, the importance of which is registered in later investigations (Dincer and Eichengreen, 2014);

$\mathrm{X} 1$ - the inflation of previous period. The previous period inflation indicator's value in the literature has already noted its importance as a driver for strengthening of monetary autonomy in the sense that the more rigorous the inflationary experience of the country was, the more it is inclined to accept an anti-inflationary institute as the independent central bank. The indicator of the previous period inflation is the average value of CPI fluctuations for 1987-1996. On one hand, during this period the hyperinflation strip was over. On the other hand, it was the most large-scale period of reforming central banks in many countries of the world. The importance of this independent variable is substantiated by the fact that the inflation experience, regardless of resources wealth, can impact the performance of the GMT-index. At the same time, the usage of this variable allows for eliminating the risk of non-commodity exporters in terms of their monetary policy success in a wider sample of countries. A logarithm was used to neutralize the impact of significant variances in the light of the fact that many countries experienced hyperinflation during the selected period;

X2 - the commodity exports share of the World Development Indicators: the Structure of Merchandise Exports, which is calculated as the sum of the positions: Agricultural Raw Materials, Fuels, Ores and Metals. In the case of island countries, the position of Food is used because it is very difficult to separate food from the agricultural raw materials for agricultural production in a tropical zone. A logarithm was used to smooth large variances when one group contains countries with minimal resource wealth and maximum resource wealth;

X3 - Democracy Index (Economist Intelligence Unit). This indicator was chosen according to two reasons. First, as already mentioned, there is a convincing positive relationship between the level of democracy or the quality of the institutions that corresponds with the democracy level, and CBI. Second, as the literature demonstrates on the issues of political economy of resources wealth, the latter often assumes an opposite correlation with the level of democracy. Therefore, these are situations when an autocratic regime monopolizes the rent and eliminates competing political and economic groups, thereby avoiding the "predatory" attitude to resources, or redistributes rent for its own benefit within socially acceptable limits. 
The inverse relationship between resources wealth and the level of democracy is connected for a number of reasons. On one hand, a dictatorial regime allows for eliminating the access to rent of competing political, economic, social, or ethnic groups, to monopolize it, to or redistribute according to the conventionally social preferences, which would correspond with maintaining loyalty to the regime. Thus, in the case of weak institutions, such a regime allows the restriction of a "predatory state" with the appropriate redistributive conflicts and macroeconomic instability, which is a struggle consequence for access to resources. Similar is the case of state fragmentation, when the lack of social trust between clearly established ethnic or political and economic groups leads to a situation of "predatory" exploitation of temporary access to resources connected with one of competing groups' electoral cycle. On the other hand, extending rent to allow for the installation of a dictatorial regime is a winning strategy for obtaining unilateral benefits that fully cover the expropriation costs and maintain control over society in the future. Third, the initial democratic regime in the conditions of a "resource curse" does not rule out that access to rent becomes the source of the "privatization" of political institutions. Therefore, democratic institutions deteriorate and are converted into substitute, concealed dividers of the consensus or into a source of social instability, economic populism, and macroeconomic vulnerability. In all three cases, the logic of tracing CBI by linking to quality of democracy and the quality of institutions must be discernible.

Most commodity economies research in this context is focused on fiscal policy, which is directly connected with resources income and rent redistribution (the review is presented by Aliyev (2013)), or on the exchange rates problem, whereas CBI is not directly analyzed. Table 8 confirms that rate fixation corresponds inversely with the level of CBI, and the political regime's role retains its relevance in this case, which allows for the inclusion of the optionality of the exchange rate regime variable into the model (1). The data in Table 8 allowsus to discard the probability of bivariant connection between the degree of exchange rate flexibility and the level of monetary authorities' independence.

The result of the regressive analysis (Table 9) admits a small statistical significance of the resource factor, in the first approximation.

\section{Table 9. Result of the regressive analysis of the relationship between the level of CBI, past inflation, the share of commodity exports, and the political regime}

\begin{tabular}{|c|}
\hline Independent variables \\
\hline Ln Past inflation \\
\hline Ln Share of commodity exports \\
\hline Democracy Index \\
\hline$R$ \\
\hline$R^{2}$ \\
\hline Adjusted $R^{2}$ \\
$F$
\end{tabular}

\begin{tabular}{|c|c|}
\hline \multicolumn{2}{|c|}{ GMT-index } \\
\hline$b$ & t-statistics \\
\hline $\begin{array}{c}0.037 \\
(0.008)\end{array}$ & 4.3495 \\
\hline $\begin{array}{c}-0.003 \\
(0.0128)\end{array}$ & -0.2364 \\
\hline $\begin{array}{c}0.051 \\
(0.0071)\end{array}$ & 7.2975 \\
\hline \multicolumn{2}{|c|}{0.585} \\
\hline \multicolumn{2}{|c|}{0.343} \\
\hline \multicolumn{2}{|c|}{0.329} \\
\hline \multicolumn{2}{|c|}{$(3.146)=25.352$} \\
\hline
\end{tabular}

Note 1. It is based on data from 150 countries using the STATISTICA software package.

Data given in Table 9 shows that the sign of the indices is theoretically predictable in all cases: past inflation, as well as a level of democracy positively affects the degree of the CBI. However, the level of democracy is the most significant factor with the most significant index. The variable of resources wealth is not found as dominant in the definition of the GMT-index. It is inferior to the democracy index (the highest coefficient) and the past inflation variable by a significant level.

Based on the results of the regressive analysis, it is possible to conclude alack of substantial conditionality of CBI upon resources wealth within a broad sample of countries. However, it can also be concluded that such a relationship may be indirect, i.e., through the relationship between resources wealth and the political regime. That is, political and institutional characteristics of a country and inflationary experience are probably more important factors than resources wealth. But the latter makes 
an impact on the independence level of monetary authorities through the inverse relationship between resources wealth and the level of democracy that has been verified in a series of other studies. This means that the independence level of monetary authorities is directly determined by past inflation and the level of democracy, while resources dependence acts rather indirectly, although clearly seen in the case of group comparisons (see above). A correlation matrix (Table 10) fully confirms the assumptions made.

\section{Table 10. Correlation matrix of relationships between the regressive model variables (1)}

\begin{tabular}{|c|c|c|c|c|}
\hline & Ln Past inflation & $\begin{array}{c}\text { Ln Share of } \\
\text { commodity exports }\end{array}$ & Democracy Index & GMT-index \\
\hline Ln Historic inflation & 1.00 & 0.002529 & -0.140396 & 0.219373 \\
\hline $\begin{array}{c}\text { Ln Share of commod- } \\
\text { ity exports }\end{array}$ & 0.002529 & 1.00 & -0.400290 & -0.233033 \\
\hline Democracy Index & -0.140396 & -0.400290 & 1.00 & 0.506168 \\
\hline GMT-index & 0.219373 & -0.233033 & 0.506168 & 1.00 \\
\hline
\end{tabular}

Note 1. It is based on data from 150 countries using the STATISTICA software package.

As the data given in Table 10 shows, the independence index value correlates with the democracy index the most densely, and the latter is inversely correlated with the resources wealth variable. Past inflation is also directly correlated with the GMT-index, while there is virtually no relationship between resources wealth and the past inflation variable. This means that resource-rich countries could be substantially different in nature regarding inflation experiences, as well as countries in which such structural characteristics as export resource dominance is not significant. It is also important to note that the level of democracy corresponds inversely with the level of inflation in the past. This can be interpreted quite definitively: more democratic countries tend to support a lower inflation level, regardless of whether they are resource-rich or not. Simultaneously, the correlation matrix confirms that the impact of resources wealth on the level of CBI is likely mediated by a political regime, i.e., the tendency of resource exporters towards an autocratic regime, which does not always coexist with a high level of inflation. This is confirmed by the case of the Persian Gulf countries. Indirectly, the correlation matrix allows us to see that when resource wealth coexists with low levels of democracy and inflation, monopolization of access to rent is not so much expropriational as it is evidence of an institutional response to the removal of "predatory behavior". In contrast, the combination of resource wealth with a low level of democracy and a high level of inflation indicates the presence of afight for rents. In the first case, $\mathrm{CBI}$ cannot be regarded as desirable in the light of significant fiscal dominance focused on intertemporal optimization. And in the second case, it can be considered as an obstacle in the fight for rent. In the case of a higher level of democracy, the combination of resource wealth and a high inflation level may indicate that the competing political and economic and ethnic groups consider the central bank as a way to gain benefits within the electoral cycle.

\section{Structural reforms in resource-rich countries and intermediate conclusions for Ukraine}

The post-Asian cycle of growth in world commodity prices has placed a greater focus on structural reforms in resource-rich countries. Most of them deal with issues of fiscal policy, optimal intertemporal savings, creating sovereign wealth funds, and economic diversification. They have also touched upon reforming monetary authorities. First of all, they concerned the adaptation of the price stability policy to an environment of strong pressure on the nominal exchange rate and a growth in gross private capital flows. More generally, they evidenced that $\mathrm{CBI}$ helps solve the problem of resource dependency due to the fact that the fiscal policy becomes more responsible, and the basic principle of the political priority to prevent "resource curse" is observed at the institutional level. For example, Chile, Peru, Mexico, Algeria, Azerbaijan, Kazakhstan, etc., have been able to demonstrate weakening the seesaw effect, which means positive changes in one area, leading to deterioration in another because of a lack of interest in actual rather than virtual reforms. According to Acemoglu et al. (2008), the "seesaw effect" provides for the following in the case of central banks: increasing CBI can improve the success of the fight against inflation, but may result in an increase in national debt, for instance, Acemoglu et al. (2008) argue that this effect is most common in societies with either severe political constraints (autocratic regime) or with weak ones (irresponsible democracy). Due to their institutional specificity, commodity economies are at risk of both types of political constraints, which is indirectly confirmed by empirical relationship between the resource wealth variable and the political regime variable (see Tables 8-9). A solution to the problem is possible on the basis of an integrated upgrade of an institutional format for macroeconomic policy, within which a low level of CBI will not be considered by functionally opportunistic groups. 
The issue of a relationship between the NBU's independence and institutional distortions of commodity economies is crucial for Ukraine. On one hand, the share of commodity exports (according to World Development Indicators) does not indicate that the domestic economy is a typical example of resource wealth. On the other hand, it demonstrated very high sensitivity to world commodity prices, institutional distortions of fighting for rent are typical, and a long-term increase in demand for food and agricultural products will deepen the dependence of domestic export on global demand conditions. This means that the choice of institutional modality for NBU functioning should rely on examples of countries where resource wealth is not dominant. Monetary policy enjoys institutional protection and is seen as an important principle of macroeconomic policy in countries with representative resource wealth or an insignificant share of commodity exports. The need to follow the chosen path to strengthen NBU independence should not be conditional on cooperation with the IMF or the choice for European integration (compliance of a formal status with assessment criteria within the ECB Convergence Report), but on a political and economic consensus with regard to structural reforms aimed at the creation of a society with high-quality institutions. In this context, the intention of the NBU to implement the mandate of price stability must be clearly crystallized, the procedure for appointment of management allows room for improvement due to increasing public awareness of the position of candidates on key areas of the central bank ex ante, quasi-fiscal operations should be minimized, and fiscal dominance should be eliminated. The same applies to the role of the exchange rate in macroeconomic priorities. Maintaining the relative stability of the realeffective exchange rate through a soft devaluation response to a decrease in commodity prices may be involved as a short-term measure. In the long run, it will turn into subsidizing commodities exporters. The policy of price stability and soft devaluation of the National Bank of Poland took place under a very different export structure and quality of institutions and therefore it cannot be similarly reproduced.

\section{E. Conclusions}

Studies of the relationship between $\mathrm{CBI}$ and the macroeconomic situation have distinguished two generations. Within the first, an emphasis was given to the specification of the independence index and interpretation of theoretically predictable relationships and deviations therefrom. Within the second, an emphasis was given to identification of drivers of enhancing the independence level and its relationship with political and institutional characteristics of countries. Recently, the unambiguous tendency with regard to the enhancement of $\mathrm{CBI}$ has been formed in the world, and the quality of institutions and the quality of democracy are recognized as the most important of its drivers. Commodity economies have evolved in a separate class of theoretical and empirical studies, which emphasize the issue of the fight for rents, the impact of such a fight on the frustration of institutions, a specific formulation of macroeconomic policy priorities, benefits of the choice of a fixed rate, and orientation on the accumulation of external assets. Custom macroeconomic priorities and institutional distortions are assumed as determinants of less independent central banks in resource-rich countries. This hypothesis has been confirmed on the basis of an inter-group comparison of the average group values of the independence index and the index of transparency of monetary authorities. The regression analysis with examples from 150 countries showed that the commodity factor has a rather indirect impact (through an inverse relationship between resource wealth and the level of democracy and a direct relationship between the latter and the GMT-index) on the level of CBI. Thus, the past inflation experience factor together with the quality of democracy is more significant, which suggests a possible nonlinear relationship between the resource wealth variable and the independence of monetary authorities. Intergroup comparisons showed that by the GMT-index, by the CWN-index, and by the transparency index, the level of CBI in countries classified as commodities exporters appeared to be lower than by a group of countries with emerging markets and developing countries. In commodity economies, there is also a tendency to increase CBI, but its level is significantly lower than in countries where the resource factor is not dominant. The analytical structure of macro-political models in commodity economies and institutional distortions therein allows for an explanation of the reason for more dependent central banks. The political and economic costly characteristics of tax collection, the fight against the "Dutch disease," the phenomenon of exchange reserves as a quasi-sovereign wealth fund, the phenomenon of a "predatory government ", the "voracity effect," the exchange measurement of rent origin have been highlighted and analyzed in the context of features of the choice of a foreign exchange regime, and the impact on policy in terms of exchange reserves and seigniorage, due to which the theoretical explanation of a functional view of a less independent central bank in commodity economies has been given. Next to that, the objectionable optimality of such an institutional choice is recognized. It is asserted that the risks of strengthening the resource dependency of the domestic economy must be considered in the context of quality institution formation policy, within which the NBU's independence is a fundamental principle of macroeconomic stability. 


\section{References}

- Acemoglu D., Johnson S., Querubin P., Robinson J. (2008). When Does Policy Reforms Works? The Case of Central Bank Independence. Working Paper, No. 14033, NBER, pp. 1-73. https://doi.org/10.3386/w14033

- Aliyev I. (2013). Procyclicality in Resource-Rich Countries. Ministry of Finance of the Czech Republic. Working Paper, No. 1, pp. 1-24.

- Aliyev R. (2012). Monetary Policy in Resource-Rich Developing Economies. Working Papers, No. 466, CERGE-El, pp. 1-49.

- Aliyev R. (2014). Determinants of the Choice of Exchange Rate Regime in Resource-Rich Countries. Working Papers, No. 527, CERGE-EI, pp. 1-36.

- Arezki R., Bruckner M. (2010). Commodity Windfalls, Polarization, and Net Foreign Assets: Panel Data Evidence on the Voracity Effect. Working Paper, No. 10-209, IMF, pp. 1-25.

- Arnone M., Laurence B., Segalotto J-F., Sommer M. (2007). Central Bank Autonomy: Lessons from Global Trends. Working Paper, No. 07-88, IMF, pp. 1-53.

- Arnone M., Laurens B., Segalotto J-F. (2006). The Measurement of Central Bank Autonomy: Survey of Models, Indicators, and Empirical Evidence. Working Paper, No. 06-227, IMF, pp. 1-56.

- Auty R. (2001). Resource Abundance and Economic Development. Oxford: Oxford University Press.

- Auty R. (2001). The Political Economy of Resource-driven Growth. European Economic Review, No. 45, pp. 839-846. https://doi.org/10.1016/S0014-2921(01)00126-X

- Berggren N., Daunfeldt S.O., Hellstrom J. (2012). Social Trust and Central Bank Independence. Paper Presented at World Congress of Public Choice Societies, Miami, pp. 1-23. https://doi.org/10.2139/ssrn.2065320

- Bodea Cr., Hicks R. (2012). Price Stability and Central Bank Independence: Discipline, Credibility and Democratic Institutions. November 6, pp. 1-42.

- Crowe C., Meade E. (2008). Central Banks Independence and Transparency: Evolution and Effectiveness. Working Paper, No. 08-119, IMF, pp. 1-30.

- Cukierman A. (1992). Central Banking Strategy, Credibility, and Independence: Theory and Evidence. Cambridge, Mass.: MIT Press.

- Cukierman A. (2008). Central Bank Independence and Monetary Policymaking Institutions: Past, Present, and Future. European Journal of Political Economy, Vol. 24, No. 4, pp. 722-736. https://doi.org/10.1016/j.ejpoleco.2008.07.007

- Cukierman A., Webb S., Neyapti B. (1992). Measuring the Independence of Central Banks and Its Effect on Policy Outcomes. World Bank Economic Review, Vol. 6, No. 3, pp. 353-398. https://doi.org/10.1093/wber/6.3.353

- Debelle G., Fischer S. (1994). How Independent Should Central Bank Be? Goals, Guidelines and Constraints Facing Monetary Policymakers, ed. by J. Fuhrer. Boston: Federal reserve Bank of Boston, pp. 195-221.

- Dincer N., Eichengreen B. (2014). Central Bank Transparency and Independence: Updates and New Measures. International Journal of Central Banking, Vol. 10, No. 1, pp. 189-253.

- Dreher A., Sturm J.-E., de Haan J. (2007). Does High Inflation Cause Central Bankers to Lose Their Job? Evidence Based on a New Data Set. KOF Working Papers, No. 167, pp. 1-21.

- Eijffinger S., Schaling E. (1993). Central Bank Independence in Twelve Industrial Countries. Banca Nazionale del Lavoro Quarterly Review, No.184, pp. 49-89.

- Frankel J. (2010). How Can Commodity Producers Make Fiscal and Monetary Policy Less Procyclicall? Paper Presented on High Level Seminar on Natural Resources, Finance and Development, Algiers, No. 4-5, pp. 1-34.

- Frankel J., Smit B., Sturzenegger F. (2008). Fiscal and Monetary Policy in Commodity Based Economy. Economics of Transition. Vol. 16, No. 4, pp. 417-448. 
- Grilli V., Masciandro D., Tabellini G. (1991). Political and Monetary Institutions and Public Financial Policies in the Industrial Countries. Economic Policy, Vol. 6, No. 13, pp. 341-392. https://doi.org/10.2307/1344630

- Habib M.M., Manolova-Kalamova M. (2007). Are There Oil Currencies? The Real Exchange Rate of Oil Exporting Countries. Working Paper, No. 839, ECB, pp. 1-39.

- Hausmann R., Rigobon R. 2002. An Alternative Interpretation of the Resource Curse: Theory and Policy Implications. Working Paper, No. 9424, NBER, pp. 1-59.

- Heimonen K., Maslowska-Jokien A. (2013). Central Bank Independence and Sovereign Debt Crisis. Any Link? Aboa Centre for Economics Discussion Paper, No. 93, pp. 1-29.

- IMF (2015). Where Are Commodity Exporters Headed? Output Growth in the Aftermath of the Commodity Boom. World Economic Outlook. Chapter 2.

- Jacome L. (2001). Legal Central Bank Independence and Inflation in Latin America During the 1990s. Working Paper, No. 01-212, IMF, pp. 1-40.

- Jacome L., Mancini-Griffoli T. (2014). A Broader Mandate. IMF Finance and Development, pp. 47-50.

- Jacome L., Vazquez F. (2005). Any Link Between Legal Central Bank Independence and Inflation? Evidence from Latin America and the Caribbean. Working Paper, No. 05-75, IMF, pp. 1-41.

- Koziuk V. (2004). Central Bank Independence. Ternopil. Carte Blanche.

- Koziuk V. (2005). Monetary problems of Global Financial Architecture Functioning. Ternopil. Aston.

- Koziuk V. (2009). Monetary Foundations of Global Financial Stability. Ternopil. TNEU, Economic Thought.

- Koziuk V. (2015). Central Bank Independence after Global Financial Crisis: Grey Zone of Status Quo. Visnyk of the National Bank of Ukraine, No. 2, pp. 16-25.

- Kurronen S. (2012). Financial Sector in Resource-Dependent Economies. Discussion Papers, No. 6, BOFIT, pp. 1-35. https://doi.org/10.2139/ssrn.2027444

- Lucotte Y. (2009). The Influence of Central Bank Independence on Budget Deficits in Developing Countries: New Evidence from Panel Data Analysis. Universited' Orleans, CNRS, pp. 1-31.

- Lybeck T. (1998). Elements of Central Bank: Autonomy and Accountability. Occasional Paper. No. 98-1, IMF.

- Mattoo A., Subramanian A. (2008). Currency Undervaluation and Sovereign Wealth Funds: A New Role for the World Trade Organization. Institute for International Economics. Working Paper, No. 08-02.

- Obstfeld M. (2000). Globalization and Macroeconomics. NBER Reporter. Fall.

- Rogoff K. (1985). The Optimal Degree to Commitment to a Monetary Target. Quarterly Journal of Economics, No. 100, pp. 1169-90. https://doi.org/10.2307/1885679

- Romelli D. (2015). Regulatory Reforms and Central Bank Independence. University of Cergy-Ponoise.

- Siklos P. (2002). The Changing Face of Central Banking: Evolutionary Trends Since World War II. Cambridge: Cambridge University Press. https://doi.org/10.1017/CBO9780511606427

- Siklos P. (2008). No Single Definition of Central Bank Independence is Right for All Countries. Paolo Baffi Centre Research Paper, No. 2, pp. 1-42.

- Wills S., van der Ploeg R. (2014). Why Do So Many Oil Exporters Peg Their Currency? Foreign Reserves As A De-facto Sovereign Wealth Fund. Paper Presented at the joint RES-SPR Conference on Macroeconomic Challenges Facing LowIncome Countries, IMF, Washington DC. Jan. 30-31. 


\title{
International Experience of Capital Flows Liberalization
}

\section{Maria Repko}

Center for Economic Strategy

\author{
Oleksandr Kashko \\ Center for Economic Strategy
}

\author{
Irina Piontkivska \\ Center for Economic Strategy
}

\begin{abstract}
In this research we concentrate on such instruments of regulatory policy as restrictions for capital flow and currency regulation. The study highlights the international experience of managing capital flows, considers the consequences of policies to manage capital flows and currency regulation in the world, and summarizes the recommendations of international financial institutions in this regard.

Given the globalization of economic processes and the high level of openness in the Ukrainian economy, a strategic goal of currency regulation reform in the country has to be the gradual liberalization of capital flows. This is particularly observed in the Association Agreement with the EU and other documents. In order to take full advantage of liberalization and minimize the risks associated with volatile capital flows, it is necessary to implement a series of measures aimed at improving institutional capacity to manage the effects of both the inflow and outflow of capital in the intermediate stages of liberalization.
\end{abstract}

The approach generally corresponds to the Comprehensive Program for Financial Sector Development in Ukraine Until 2020, the IMF, and the Memorandum of Association Agreement between Ukraine and the EU.

JEL Codes: F2, F3, G18, G28

Keywords: cross-border capital flows, currency regulation, liberalization, international experience

\section{Why the international liberalization experience is relevant for Ukraine?}

The economic decline and capital ouflows triggered by the deployment of military operations, combined with the political and economic crisis forced the NBU to resort to harsh currency regulation measures to calm the foreign exchange market in 2014-15. Implemented by the NBU, administrative measures of currency regulation helped stabilize the foreign exchange market and improve the balance of payments, but these measures coupled with an outdated configuration of currency regulation constrained the process of economic recovery. Therefore, currency regulation liberalization is a top priority in economic policy today.

For Ukraine it is even more important that throughout the period of independence, cross-border capital movement was limited, especially in residents' investment abroad and the existing legal framework remains from the early post-Soviet era.

On the one hand, relatively easy inflow of foreign currency loans during the global upward cycle in the mid-2000s turned to disastrous outflow with the global downturn in 2008-2009. This led to the rapid growth of companies' leverage and deteriorating asset quality of the banking system due to sharp hryvnia devaluation. Subsequently, a similar problem befell the state because the budget deficit and balance of payments was financed through external borrowing, and after the crisis of 2014-2015 the debt burden on the budget has soared. Hryvnia depreciation increased the value of debt denominated in foreign currency and is responsible for about two-thirds of the total increase in the ratio of public debt to GDP. 
On the other hand, since independence, Ukrainian economic agent-residents had almost no opportunity to invest in foreign assets and their investment were limited by offshore jurisdictions for the purpose of tax optimization and large business/HNWI investment. Even with quite limited access to the world's financial markets, there was close to zero development of the internal securities market and corporate governance.

A high-quality and wide financial services market (asset management, private pension funds, hedge funds, etc.) failed to develop. The hypothesis that may explain this situation (even though it requires a separate study) may be the lack of competition for investors' funds from foreign issuers with high standards of transparency, corporate governance, and proper protection of shareholders' and creditors' rights. The absence of an effective judicial system played a role to a fair extent. The main investment instruments are deposits in banks and (to the households) cash foreign currency.

At the same time, the banking supervision standards were relatively weak, which allowed owners of banks with Ukrainian capital to channel depositors' funds to related companies and/or to use banks as settlement centers for their businesses. Since 2014, the National Bank has expelled 64 insolvent banks out of the market and five banks are being managed by the temporary administration. Altogether, it is about $40 \%$ of the total number of banks operating in Ukraine before the 2014 crisis. It is noteworthy that none of liquidated banks were owned by foreign banking groups. At the end of 2015, among the 13 largest Ukrainian banks (about $80 \%$ of banking system assets), only five belonged to Ukrainian owners (the government owned three of them). Thus, we can say that the liberalization of the share capital in the post-Soviet era and, consequently, the appearance of foreign banking capital in Ukraine, from this point of view contributed to the stability of the banking system.

Given the globalization of economic processes and the high level of openness in the Ukrainian economy, a strategic goal of currency regulation reform in the country has to be the gradual liberalization of capital flows. This is particularly observed in the Association Agreement with the EU and other documents. In order to take full advantage of liberalization and minimize the risks associated with volatile capital flows, it is necessary to implement a series of measures aimed at improving institutional capacity to manage the effects of both the capital inflow and outflow at the intermediate stages of liberalization.

The liberalization of cross-border capital movements contributes to the acceleration of economic development, since foreign capital inflows allow structural financing of the current account deficit, arising from rapid growth in investment and consumer activity. In the long-term, capital inflow contributes to the financial sector development in recipient countries and expanding opportunities for investment in the country by facilitating the access of economic agents to financial resources, thereby stimulating economic growth.

According to the recommendations of the IMF (2013a), removal of restrictions on capital movement, which regulator imposed to combat the crisis, should be gradual and follow prudent steps because, in developing world, recipient countries bear the economic risks associated with the reduction of barriers to international capital flows. High pro-cyclicality of global capital flows for developing countries, leads to even more severe cyclical economic processes during periods of growth and decline. In Ukraine, we were able to observe this effect during 2008-2009 and 2014-2015 when the trend reversal of debt capital inflows predetermined a severe balance of payments crisis and led to the depreciation of the hryvnia after a long period of a de facto fixed rate (Figure 1).

\section{Figure 1. Balance of payments and the official rate USD/UAH}

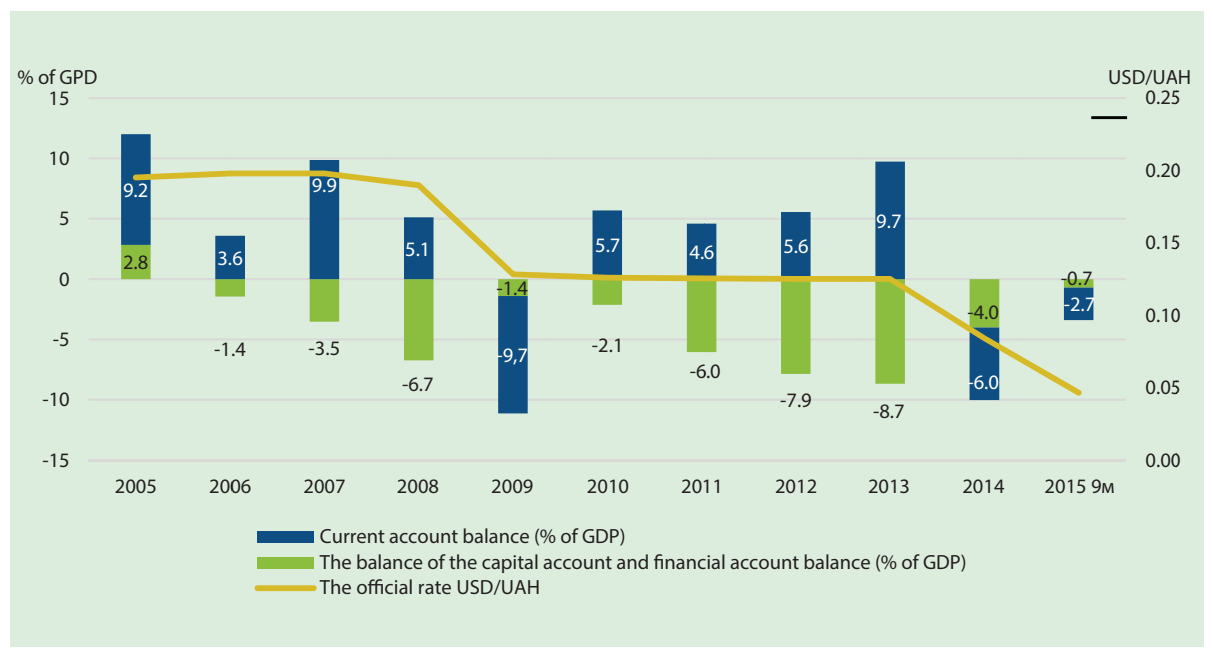

Source: National Bank of Ukraine statistical data. 
Therefore, during the process of financial liberalization many developing countries used to and still practice the use of capital control tools to mitigate the negative effects of a sharp inflow or outflow of capital for their economies (Kose et al., 2012; World Bank, 2005). The use of capital flows restrictions depends on causes and the extent of problems that arose in the economy.

In particular, accumulated international experience on the use of restrictions on capital flows, e.g., IMF (2013a), IMF (2013b), suggests that:

- use of administrative restrictions must be temporary anti-crisis measure;

- it is easier to control capital inflows than outflows;

- restrictions should be momentary and widespread;

- the effectiveness of restrictions on the capital movement is higher if the country's financial system has high standards of regulation and supervision, which reduces the risks of bypassing such restrictions; and

- the introduction of new restrictions entail high administrative costs.

Therefore, the implementation of financial liberalization must take into account the experience of countries that have their international capital flows liberalized and recommendations of international organizations that were involved in this process in different countries. This helps to minimize the risk of the crises and achieve maximum economic benefits from liberalization. Therefore, in this paper we focus on international experience coverage on the issue and the recommendations of international organizations, which must be considered in formulating future policy of capital flows management in Ukraine.

\section{The benefits and risks of liberalized capital movements}

Due to globalization and the development of financial tools and services, as well as the open nature of the Ukrainian economy, financial liberalization is an inevitable process that will speed up economic development, promote more efficient use of resources (both financial and material), help spread modern technology, and improve opportunities to diversify risks. This ultimately creates a foundation for sustainable and balanced economic development and public welfare.

The full liberalization of capital movements stimulates long-term capital inflows to the real economy and the realization of Ukraine's economic potential. The presence of free exit from investments in Ukrainian assets and simplified procedures for converting and transferring currency are crucial factors of new investments inflow and the development and strengthening of the liquidity of the domestic financial sector. This, in turn, will contribute to the development of currency risk hedging instruments and other financial instruments. As a result, real sector enterprises will have better financing conditions - both by expanding the number of instruments and due to the lower cost of capital. Households get better conditions for savings allocation, including pensions. The money market liquidity increase will boost the demand for hryvnia due to additional demand and supply from foreign players and will reduce the load on the Central Bank's reserves during periods of speculative fluctuations.

For Ukrainian companies and households, capital outflows liberalization will expand opportunities for diversification of assets. Facilitating the access of economic agents to foreign financial resources will contribute to smoothing fluctuations in consumption and investment in the event of external shocks in major export markets.

However, financial liberalization will promote deeper integration of Ukrainian economy into global economic processes that may cause greater volatility in exchange rates and require higher standards of risk management by both regulators and other market participants. 


\section{Table 1. Advantages and disadvantages of capital free movement for emerging economies}

\begin{tabular}{|c|c|c|}
\hline & Free capital movement & Limited capital movement \\
\hline \multirow{8}{*}{ 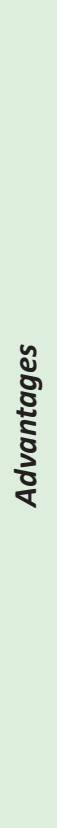 } & Better access to international investment capital & Government deficit financing at below market rates \\
\hline & Lower market rates the real sector funding & More autonomous monetary policy \\
\hline & $\begin{array}{l}\text { A wide range of financial instruments for domestic } \\
\text { investors }\end{array}$ & $\begin{array}{l}\text { The perspective of government preferences for certain } \\
\text { market participants }\end{array}$ \\
\hline & Developed internal financial sector & $\begin{array}{l}\text { The possibility of lower volatility for the exchange rate or } \\
\text { setting the fixed rate }\end{array}$ \\
\hline & $\begin{array}{l}\text { The development of pension funds which receive the } \\
\text { opportunities to diversify }\end{array}$ & \\
\hline & Higher fiscal discipline & \\
\hline & Higher productivity of investments & \\
\hline & Competitive environment & \\
\hline \multirow{10}{*}{ 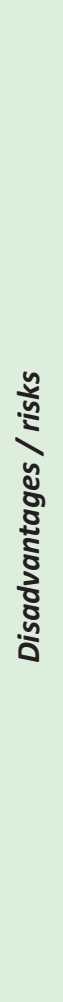 } & The high volatility of capital flows & Real sector has limited access to the financial resources \\
\hline & Budget deficit financing on market principles & Less competitive environment in the financial sector \\
\hline & Greater volatility of exchange rate & Higher cost of funds \\
\hline & $\begin{array}{l}\text { The need for setting high standards of prudential } \\
\text { supervision }\end{array}$ & Higher probability of unproductive investments \\
\hline & $\begin{array}{l}\text { Less autonomy and the need for more active monetary } \\
\text { policy }\end{array}$ & High cost of conducting business \\
\hline & Higher probability of entering crises & Low level of financial sector development \\
\hline & & $\begin{array}{l}\text { Limited range of financial instruments for domestic } \\
\text { investors }\end{array}$ \\
\hline & & Low level of risk management in the financial sector \\
\hline & & More likely market distortions (rent seeking, corruption) \\
\hline & & High administrative costs of capital restrictions \\
\hline
\end{tabular}

Source: Economic Strategy Center. 
Capital liberalization risks multiply if liberalization occurs in a country that hasn't reached a sufficient level of financial and institutional development (the first attempts to liberalize in Turkey and Israel provide an example), IMF (2013b). In the absence of an appropriate level of prudential regulation and supervision (which has constantly improved in light of the development of financial innovation), the financial openness of the economy could create incentives for financial institutions to take risks that are too high, which ultimately leads to the inflow of short-term volatile investments, especially in non-tradable sectors (for example, the real estate market). As a result, it may create a "price bubbles" in such markets. Sudden investment outflow could cause a liquidity crisis and banking difficulties, World Bank (2005). However, Hartwell's (2014) recent research showed that the probability of entering a crisis decreased with the deepening of the financial liberalization process subject to prudent macroeconomic policies and exchange rate flexibility.

From a regulatory point of view, free capital movement imposes restrictions on the monetary policy' autonomy for a small open economy like Ukraine, as the central bank faces a "classic trilemma," since one cannot control the cost of money in the country, the exchange rate, and capital flows simultaneously. Monetary policy in financially open developing economies can have a degree of autonomy, although there are restrictions on the objectives that it can achieve Obstfeld (2015). Obstfeld notes that countries with no fixed exchange rate are thought to have a certain degree of monetary autonomy, including the impact on short-term interest rates, but long-term interest rates show a high degree of correlation in various countries regardless of the exchange rate regime.

\section{International experience}

Given the overall globalization, the world generally tends to liberalize financial flows, including those among developing countries and countries with economies in transition. Changes in the index of capital restrictions (calculated based on the annual report of the IMF on foreign exchange regimes and restrictions on the capital movement (IMF, Annual Reports)), show that the number of economies classified as mainly financially open, from mid-1990 to 2010, increased from 78 to 93 from among 185 countries, Chinn and Ito (2015). However, the number of mostly financially closed economies only slightly decreased over the same period (65 to 62 ).

The liberalization of cross-border capital movements contributes to the acceleration of economic development, since foreign capital inflows allow structural financing of the current account deficit, arising from rapid growth in investment and consumer activity. Also, free international capital mobility allows diversifying investments. Empirical studies of Saadi and Sun (2012), on the impact of capital flows on economic development, point to the positive effects of foreign direct investment and other non-debts flows, especially to developing countries and countries with economies in transition, including through the positive effects of modern technology imports. In the long-term, capital inflow contributes to financial sector development in recipient countries and expanding opportunities for investment in the country, facilitating economic agents' access to financial resources and promoting economic development.

The experience of the countries that liberalized capital movements tended to show sustainable economic growth in the long run and not only by foreign direct investment, where the positive impact on the economic development of recipient countries is well documented in economic literature, but is also due to the influx of more volatile categories of investments, IMF (2013b). Figure 2 shows a positive correlation between the net inflow of foreign investments item "other investment flows"1 ${ }^{1}$ after full financial liberalization, and the average economic growth for 10 years after that indirectly testifies in favor of liberalization in the long run, though it is not proof of one depending on the other since economic growth is determined by many different factors other than foreign investment.

\footnotetext{
1 "Other investment flows" - investment category, which is characterized by high volatility, it does not include foreign direct and portfolio investments and derivative financial instruments. IMF (2007), Balance of Payments and International Investment Position Manual. 6th Edition, Chapter 6. https://www.imf.org/external/pubs/ft/ bop/2007/pdf/chap6.pdf
} 


\section{Figure 2. Correlation between long-term economic growth and investment flow changes in the volume from abroad in the period, one year before the liberalization / one year after liberalization}

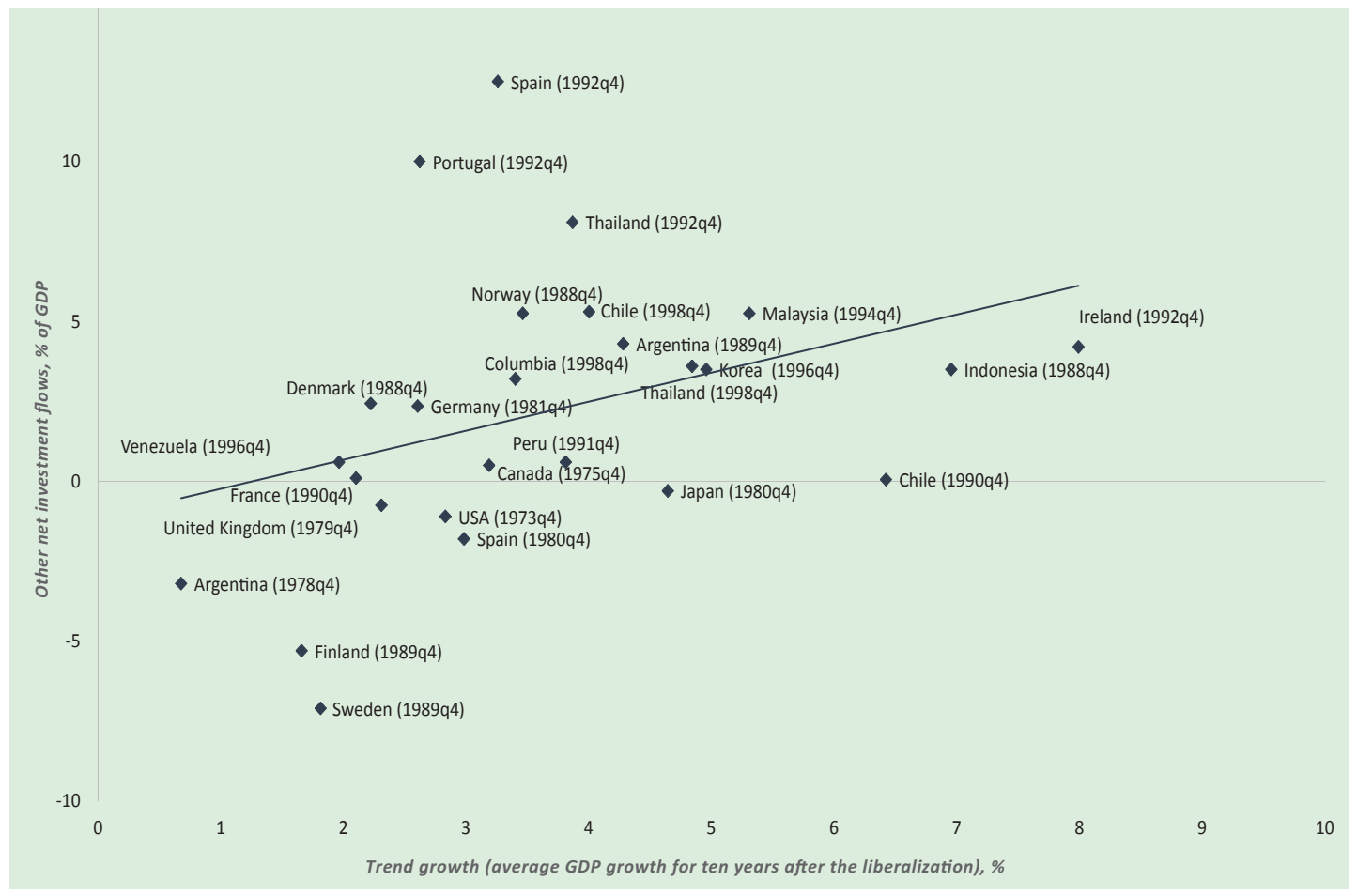

* The growth trend is defined as the average real GDP growth for ten years after full liberalization.

Source: IMF (2013b).

On the negative side, the high pro-cyclicality of global capital movements leads to volatility of capital flows into and out of the country, and it also leads to more pronounced cyclical domestic economic processes - periods of growth and decline. Thus, for developing countries, if they are recipients of capital flows, it may exacerbate cyclical fluctuations and risks associated with them and will require appropriate and rapid correction of fiscal and monetary policy.

The countries' experiences that liberalized capital flows showed that, in the first years after opening the capital account, there was a massive capital inflow into the country, IMF (2012a), IMF (2013b), Hartwell (2014). This caused upward pressure on the recipient country currency, which was difficult to withstand with the help of sterilization operations via the central bank. As a result, the export competitiveness decreased causing further deterioration of the balance of trade, and the prices of non-trading sectors grew unreasonably fast (boom in the real estate markets), as well as domestic credit, consumption, and investment due to the inflow of funds from abroad, including short-term debt. This eventually led to the deterioration of macroeconomic indicators - the expansion of the current account deficit, increased inflationary pressures, a slowdown in the growth of GDP, and then reduced inflow or even outflow of foreign capital even in the absence of other negative factors.

With cyclical fluctuations in global markets, a sharp switch from capital inflows to outflows led to the downward pressure increased, prices fell in real estate markets, and the level of non-performing assets on the balance sheets of banks increased at an exorbitant pace. Depending on the scale of these processes, emerging countries saw temporary financial difficulties or entered a systemic crisis of balance of payments, banking sector crisis, and/or currency crisis. This required an adjustment of monetary and fiscal policy and often the need to re-impose the capital movement restrictions.

The accumulated experience of overcoming crisis consequences and the use of different tools makes it possible to draw conclusions about the efficiency of various capital control policy measures that let regulators to avoid or reduce the negative effects of volatile capital flows in developing countries. 


\subsection{The nature of the capital movement management}

In the process of financial liberalization, many developing countries practiced and still practice use of capital controls to reduce the negative effects of sharp capital inflow or outflow for their economies, (IMF, Annual Reports).

\section{Administrative and market-oriented capital flow management tools}

The use of capital flows management instruments depends on the causes and extent of problems that arise in the economy. There are two broad categories of capital movement restrictions, Klein (2012), Table 2:

1) administrative constraints (permits, prohibitions on certain transactions);

2) market-oriented or price-based control measures (such as taxation, reserve requirements, etc.).

\section{Table 2. Examples of capital movement restrictions and examples of their use}

Restricting capital outflows
The prohibition of repatriating divi-
dends

Limitations (moratorium) on withdrawal of deposits and purchase of FX in cash

Mandatory sale of export proceeds
Holding period on transfers to non-
residents for proceeds from the sale of
domestic assets
Minimum lock-in period for foreign
capital

Delay on converting non-resident income from the sale of domestic assets (from 5 days to 12 months)

Prohibition on the conversion of assets denominated in local currency

Taxing the sale of securities by nonresidents

Multiple exchange rates

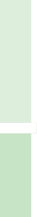

\section{Restricting capital inflows}

\section{Administrative}

Ukraine (2014-

2015), Malaysia

(1998)

Ukraine (2014-

2015), Argentina

(1994, 2001)

\section{Ukraine (1998, \\ 2014), Thailand \\ (1997)}

Iceland (2008)

\section{Chile (1990s), India}

Ukraine (2008),

Malaysia (1998)

Iceland (2008)

\section{Market oriented (price-based)}

Malaysia (1998)

Argentina (2002-

2013), Venezuela

(2003-2015) residents tracts rowings non-residents
Limits to attract short-term capital by

A minimum holding period of domestic assets for resale on the balance sheet

Requirement to obtain permission or registration of international borrowing con-

Restrictions on the maturity of debt bor-

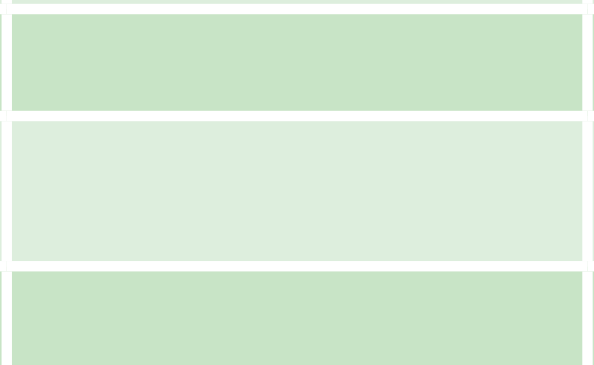

Taxation of interest income and income from the sale of domestic securities by

Reservation of short-term capital inflows in separate accounts in the Central Bank

Taxation of portfolio investments and inflow of debt capital
Indonesia (2011)

India, Indonesia (2011)

Korea (2010), Cyprus, Ukraine India, Ukraine (2008)

Korea (2011), Thailand (2010)

Chile (1990s), Slovenia (199599)

Brazil (2009) 
Usually administrative restrictions are less transparent, more discretionary (they are given at the discretion of the official who makes decisions), and more distorting for activities of economic agents, while market-oriented restrictions call rather for non-stimulation of certain transactions, increasing their cost and not fully banning them, and they are transparent, clear, and binding rules of the game under which the market works.

\section{The duration of capital controls application}

Prolonged use of a capital control policy in most cases is considered as the one that has a negative impact on the economy, IMF (2012a), Klein (2012), Saborowski, Sanya, Weisfeld, Yepez (2014). In particular, it reduces the financial markets' discipline and control of public finances, narrows the scope for financing investment projects, and reduces the opportunities for residents to diversify their assets that negatively affects economic growth. There are also government costs related to monitoring and control of compliance with foreign exchange regulations and other restrictions. The existence of restrictions indirectly encourages economic agents towards rent-seeking behavior and corruption in order to be able to evade them. Thus, prolonged use of capital controls is counterproductive since they force the regulator to modify its rules constantly in order to keep the cross-border transactions under control that constantly increases costs for the state and economic agents.

A debatable exception in this regard is China, where the cross-border movement of capital was limited for a long time and that has not prevented its economy to grow. Capital controls in China were bypassed as described by Ma and McCauley (2007) thanks to the parallel existence of broad "offshore" and "onshore" currency markets, and from 2009 to 2014 the major problem was to control inflows rather than capital outflows, which reversed only in 2015. Current trends in the Chinese economy and stock market still need to be studied in terms of the effectiveness and appropriateness of capital control mechanisms that were applied by the government over time. But in any case, the China example for Ukraine is less relevant than the examples of smaller countries (Poland, Iceland, Asian countries) as it relates to small open economies.

As Krugman (1998) formulated, for capital controls to become an effective tool in overcoming the crisis, and not become a cause of economic stagnation, structural deformation, lack of foreign investment flows, and more funds in the informal sector, their limitations should be:

- to be aimed to disrupt ordinary businesses as little as possible;

- to be regarded as temporary measures, designed to win breathing room for economic recovery, not as permanent practice;

- to not use them to protect overvalued currency, they should not evolve from a temporary defense against speculations into a permanent system of protectionism; and

- to serve as an aid to reform, not an alternative.

\subsection{Prerequisites for the complete removal of capital flows restrictions}

Given the lessons of the global financial crisis, the IMF currently does not recommend implementing measures to fully open capital accounts for countries that have not reached a certain level of domestic financial sector development and institutional capacity. International experience shows that liberalization of capital movements is more likely to be successful in the case of prudent fiscal, monetary, and exchange rate policy, IMF (2012a), Arvai (2005). Flexible exchange rates can help smooth out shocks from volatility in capital flows to the real economy, IMF (2012b).

According to the IMF recommendations that were developed based on member countries' experiences, IMF (2012a), IMF (2012b), which introduced measures liberalizing capital accounts, the prerequsities for the full and complete removal of capital movement restrictions are as follows:

- sustainable economic growth;

- low inflation and high exchange rate flexibility;

- an adequate level of international reserves;

- a significant proportion of FDI and equity capital in the composition of capital inflows;

- an adequate level of financial sector development;

- high standards of prudential supervision and regulation;

- a positive perception by investors of the quality of governance and institutions in the country; and

- fully liberalized current account. 


\subsection{The sequence of steps to liberalize the capital account}

Economic thought is unequivocal about the falsity of the idea of an instantaneous liberalization of capital flows, even with the implementation of the above prerequisites.

Based different countries' experiences, the IMF recommends following a certain sequence in removing restrictions on capital movement to reduce the negative effects of the high volatility of international capital, IMF (2012b), Figure 3.

\section{Figure 3. A generalized diagram of measures to liberalize capital}

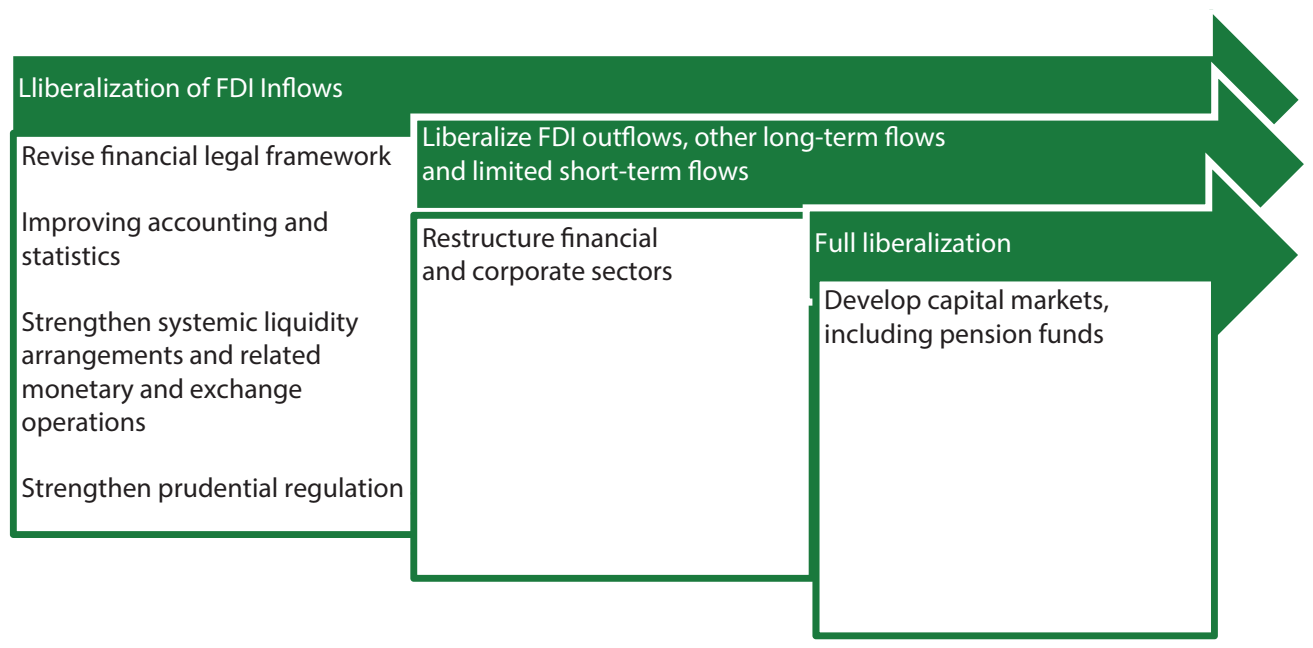

Source: IMF (2012b). http://www.imf.org/external/np/pp/eng/2012/031312.pdf.

\subsection{Selecting the pace of capital account liberalization}

The capital flows liberalization pace slowed in recent decades through repeated commencement of crises in different countries. Many countries have introduced new or returned to previously used measures limiting cross-border capital movement in crisis episodes to reduce the negative effects of the high volatility of capital flows on their economies (Israel, Latin America, Iceland).

Experience, such as the immediate liberalization in Israel in 1977, shows that the shock therapy without proper macrostability and developed financial markets can greatly deepen the crisis. IMF (2013b).

Israeli's two attempts of financial liberalization

First attempt of liberalization, 1977, also called the "Big Bang"

- Sudden onset and rapid progress

- Instability of policies that worsened macroeconomic conditions

- Financial markets were controlled by the regulator, there were no developed capital markets and money markets

- Led to inflation growth and capital flight along with rapid devaluation

- Recognized as failed and dismantled in 1979

The second attempt of liberalization in 1987

- Gradually, slowly implemented

- Relatively stable, improved macroeconomic conditions

- implemented against the background of macroeconomic reforms, disinflation, gradual liberalization of the exchange rate and deregulation of the capital markets

Completed in 2005.

Source: IMF (2013b). 
Now economists agree that liberalization must be conducted with no reference to dates and terms, but to the occurrence of certain events or stages of economic development, IMF (2013a), IMF (2012a), IMF (2012b).

International experience shows that the liberalization of capital movements is a lengthy process because it requires complex reforms and development of the market infrastructure. The time required for the necessary reforms in the country to create the conditions for safely opening the capital account depends on each country's specifics, but even in industrialized countries this process was sometimes quite lengthy (for instance, liberalization of capital movements lasted 16 years in Japan), IMF (2013b).

Among developing countries over the past decade, there are many examples of rapid financial liberalization, after which crises happened. Relatively painless (within 7-10 years) capital flows liberalization was conducted in Central and Eastern European countries, Arvai (2005), probably due to their success with the European integration process and the support from the European Union. As to the opening of capital accounts, countries such as Poland, Hungary, Czech Republic, and Slovenia already had well developed financial sectors and institutions and were recipients of large amounts of FDI. Among Central and Eastern Europe countries, the liberalization process took course relatively quickly in the Czech Republic: the main measures were implemented during 1993-1995 and the final opening of the capital account ended in 2001, Arvai (2005). During this period, the Czech Republic has endured one crisis episode, it was the currency crisis of 1997, which provoked the departure from a fixed exchange rate policy. The pace of financial liberalization in Poland was longer and more gradual than in neighboring countries (lasted 16 years), but the country managed to avoid crisis episodes and did not have to re-impose restrictions that had been taken earlier , Arvai (2005) Kokoszczyñski (2001) (see the Polish Experience section).

In Iceland, capital liberalization movements in the absence of appropriate prudential regulation and capital inflows restrictions exceeded the absorptive capacity of the economy and this led to a deep crisis, which triggered by a global crisis in 2008, Ostaszewski (2013), IMF (2015). Resorting to capital restrictions practice in Iceland was a necessary step on the part of authorities to gain control and manage the macro-financial stability. (See the Iceland Experience section).

Examples of successful and unsuccessful processes of liberalizing capital flows and the use of restrictions during the Asian crisis are Malaysia and Thailand, respectively. An integrated approach has helped Malaysia to confront the global financial crisis with fewer losses than in Thailand (see the Thailand and Malaysia Experience section).

The process of capital account liberalization in Korea in the last decade is consistent with the generally recognized integrated approach when lifting restrictions has been accompanied by prudent macroeconomic policies, IMF (2012).

\section{Polish Experience}

\section{Background}

Public policy: the public policy was shaped in the 1990s, after the collapse of the Soviet Union when Poland was going through a period of transformation from a planned to a market economy. At the beginning of transformation, the country suffered from hyperinflation. Part of the stabilization program after a major devaluation was linking the fixed exchange rate to the dollar, Kokoszczyñski (2001). In 1991, with a growing proportion of developed economies in its foreign trade structure, Poland abandoned the fixed exchange rate by switching to a crawling peg regime based on a basket of currencies. In 1994, due to improved balance of trade and capital inflows associated with privatization, partial convertibility of the Polish zloty became possible, first in the currency band regime (crawling band) and then a move to a flexible exchange rate. This lead to the country's foreign exchange market development, along with it came the stock market as a result of privatization. All important indicators (interest rates, exchange rates, credit limit) were rigidly controlled, Kattel, Kregel and Tonveronachi (ed.) (2016).

Financial Sector: The rehabilitation of the financial system held together with tectonic transformation processes in the economy. In the early 1990s, the financial sector consisted mainly of banks; besides them, there was only one state insurance company. Thus, Poland had to build its financial system from scratch.

Economic growth: In 1990, the first post-Soviet Polish government introduced the "Program of economic transformation," designed to stabilize the economy and implement structural reforms as the first steps on the way from a planned to a market economy. 


\section{The transformation process}

First stage. Reconstruction of the financial system and its regulation. The large-scale financial system transformation in Poland began in 1989 and lasted until the late 1990s. Parliament passed the Banking Act and the Act of the National Bank of Poland, thus forming a two-tier financial system, and commercial banks appeared. Removal of restrictions on the foreign banks' activities also refers to the earlier transformation time and licensing conditions for new banks were simple. In 1991 the country already had 72 commercial banks. Many of them were European and actively participated in the privatization process, thus establishing an economic ties with the EU even without formal entry into the Union.

Second stage. Formal integration. Poland's formal integration with the European Union and the country's implementation of the changes to the regulation of financial markets demanded by the OECD included the creation of an entirely new regulation package that Poland simply adapted over time using existing EU regulations. In 1997, amendments were made to basic legislation and regulation of the financial sector in Poland, fully consistent with EU guidelines. Small differences that remained were eliminated in 2004. The new Foreign Exchange Act of 2002 lifted the most restrictions on the capital movement with EU countries and the OECD member countries. Polish residents were free to invest in the capital markets of these countries, hold accounts in foreign banks, and invest funds in such accounts. This had not led to economic disaster. The temporary capital outflows on portfolio transactions in equities, which was observed in 2001-2003 (-0.2\% to -0.4\% of GDP), changed to inflows in 2004-2005 in the amount of 0.4\%-0.7\% of GDP, and the capitalization of the domestic stock market almost tripled from $13.7 \%$ of GDP in 2001 to $30.9 \%$ of GDP in 2005.

The third stage. Continued liberalization. Since 2007, Poland mostly continued its adjustment to EU standards, particularly by liberalizing investment funds' operations and debt regulation. Restrictions on foreign exchange settlements between residents in the country had not been withdrawn. In 2010, Poland implemented investors' protection legislation (requirements of the European Directive Markets in Financial Instruments Directive), particularly in terms of the detail and quality of information on the tools and terms of financial services, evaluation of the consumer's understanding of the product, and verification of the risks related to investor's skills and product knowledge.

\section{Conclusions}

With legislation being gradually brought in line with European directives and liberalization of capital movements, Poland managed to integrate into the global financial system, avoiding significant crises related to capital outflows. Even during the crisis of 2008, no financial institution went bankrupt, and NPLs remained at more or less controlled level. The main reasons for the success of such a policy were strong prudential regulation and supervision of the financial services market, and the regulator's flexible response to internal and external challenges (changing the capitalization requirements, making the act of state guarantees in the recapitalization of financial institutions, many formal recommendations for the management of credit and currency the risk of work with derivatives, etc.).

Sources: IMF (2013b), Kokoszczyñski (2001), Kattel, Kregel and Tonveronachi (ed.) (2016).

\section{Iceland Experience}

\section{Background}

Public policy: Since 1980, the Icelandic government took a course on liberalization, deregulation, and reduction of intervention in the state's economy. During the 1990s, the central bank moved to inflation targeting, fully implemented in 2001, and a floating exchange rate. At the same time, Iceland joined the European Economic Area and legally declared free capital movement.

Financial Sector: In 2003, privatization of the country's three largest banks was completed and the government began to provide its guarantees for mortgage loans. This led to a credit boom. At the same time, interest rates higher than the average European level made appealing investments to the Icelandic currency and derivative instruments for non-residents. Given the fully liberalized movement of capital, banks had virtually uncontrolled access to foreign borrowings and channeled them to both the domestic market and high-yield foreign assets. Rapid development of the credit market was inconsistent with the level of economic development, and Icelandic banks, using leverage, increased their total assets to as much as $1000 \%$ of GDP as of 2007.

Economic growth: The Icelandic economy grew (cumulatively $+25 \%$ during 2003-2007) due to a carry-trade currency speculation scheme, high interest rates of the Central Bank, and strengthening of the national currency against the background of prevailing capital inflows. This led to an accumulation of excessive private sector debt (corporate sector debt as of 2008 accounted for $308 \%$ of GDP) and a significant dependence on foreign financing. 


\section{$\underline{\text { Crisis }}$}

First stage. The crisis development. With the Lehman Brothers bankruptcy and the collapse of world stock markets, rapid capital outflow began. The domestic price of financial assets and real estate collapsed and the opportunity to refinance debt disappeared. As a result, Icelandic banks lost liquidity and banking sector collapsed. This caused panic in the financial markets and a new significant capital outflow resulted in a balance of payments deficit and the depreciation of the Icelandic krona.

Second stage. Soft regulation. In an attempt to resolve the situation, the government was forced to nationalize the three largest banks. But since Iceland declared free capital movement by law, the central bank did not have sufficient powers to resolve the situation. The central bank raised interest rates to $18 \%$, but it did not help and capital flight continued. The government signed an agreement with the IMF for the period of 2008-2011.

The third stage. Administrative restrictions. To introduce additional restrictions on capital movement Iceland had to legally empower the Central Bank to manage the capital flows. The first restrictions on capital flows imposed by the Central Bank in November 2008 prohibited or significantly limited any cross-border movement of capital not related to international trade. The restrictions had immediate effect; in the same quarter (in IV quarter 2008), the capital outflow almost completely stopped and the exchange rate stabilized (Figure 4).

The fourth stage. "Crackdown". Since economic agents eventually found opportunities to bypass restrictions, the regulator had to review them in 2009 and 2011, mainly in the direction of strengthening regulation. Partial exceptions were made for public institutions or companies, and those companies where the state had a significant stake. Nevertheless, during the time when capital flows restrictions were in force, up to one third of the failed banks' assets flew out of the country via various channels.

The fifth stage. Stagnation. The above restrictions on capital movement, established in November-December 2008, are still in force today. According to Iceland's Ministry of Finance, maintenance of restrictions on the capital movement costs the Icelandic economy 2-3\% of annual GDP growth. In September 2009, the first program for financial liberalization was presented, but it did not receive adequate support and was not implemented, so another program was presented in March 2011.

\section{Figure 4. Payments dynamics and the capital movement restrictions in Iceland}

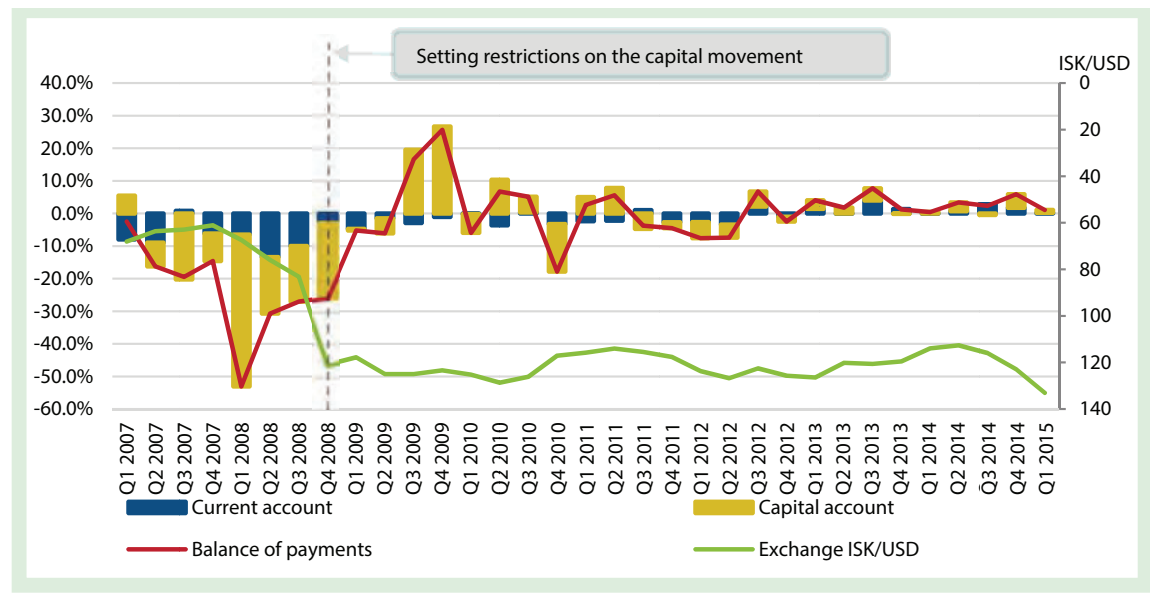

Source: according to the Iceland Central Bank.

The sixth stage. The liberalization. Thus, most of restrictions existed until 2015. During this time, the balance of payments has stabilized, the country started with a surplus for the third consecutive year (in 2014 the surplus was US\$ 1.45 billion), and GDP started to grow in 2011. In 2015, a liberalization program was adopted. The total amount of funds that would be withdrawn, in case of simultaneous restrictions lifting, according to the Iceland Ministry of Finance is more than 1.7 trillion euros ( US\$ 12 billion, 70\% of GDP), IMF (2012a). Assets on US\$ 9 billion (52\% of GDP) could be withdrawn from the country immediately in the case of full financial liberalization and thereby disrupt the macroeconomic stability, triggering a panic on the currency market. Because of this risk, the Ministry of Finance decided to define the following groups of assets: 
- money for depositors of failed banks denominated in krona ? ( US\$ 3.5 billion, 20\% of GDP);

- money for resident depositors of failed banks denominated in FX - ( US\$2.8 billion, 16.5\% of GDP);

- money for financial instruments of non-residents denominated in krona - (US\$ 2.1 billion, 12.4\% of GDP).

For each of these groups, its own liberalization strategy was developed, designed to smooth the maximum impact on the macroeconomic situation. Of course, the future financial flows are not limited to the groups mentioned above and therefore, with increased financial freedom in Iceland, the Central Bank will have to modify prudential supervision and authorize investments in order to avoid repeating of the crisis.

\section{Conclusions}

Against the background of capital account liberalization with inadequate levels of prudential supervision and institutional constraints of the regulator (superimposed by signed international agreements), Iceland faced considerable economic difficulties, the effects of which the country has yet to break. After 7 years, severe restrictions on capital movement remain in place concerning almost all aspects of international capital flows. Now, the Icelandic government has created a roadmap for the gradual lifting of restrictions on capital movement, clearly defining key asset groups and individual policies for each of them. In the plans of the government and the central bank, strengthening prudential supervision in order to prevent similar situations in the future holds a special place.

Sources: Ostaszewski (2013), IMF (2015), Capital Account Liberalization Strategy. (2015), Central Bank of Iceland (2011).

\section{The Thailand and Malaysia experience}

\section{Background}

Economic growth: The Thai economy rapidly evolved over 1980-90, with an average growth rate of 7.6\% per year. In total, from 1980 to 1996, the GDP of Thailand increased 3.9 times. Due to low labor costs, the country's exports had a significant competitive advantage and was rapidly growing. The main factors that determined the inflow of foreign investment were the recession in the US and the low US Federal Reserve interest rates, which caused investment flows from the United States abroad. Thailand at this time was attractive for investments because of the central bank's high interest rates (13\% in 1995), the currency pegged to the dollar, and liberalized capital movements.

Public policy: Since 1993 the Thailand Bank decided to develop the Thai financial system as a regional financial center. A key role in this process was to be played by a system of offshore banks institutions (Bangkok International Banking Facilities, or BIBFs). In 1994, exchange controls were loosened and transfers abroad eased (investments and loans). Interest rates remained high and the currency was pegged to the dollar.

Financial sector: The basic scheme of a licensed BIBF was to attract foreign funds for lending to residents (out-in operation) and non-residents (out-out transactions). The lack of business transparency, weak bank supervision, too low capital requirements, and inadequate bankruptcy procedures encouraged unscrupulous practices by banks. Combined with low-cost loans, it led to buying into the low-quality assets and to specultaions, especially in real estate sector, where investments were protected by the government.

\section{Crisis}

First stage. The crisis development. When the US Federal Reserve interest rates began rising with the subsequent strengthening of the dollar, the capital flows reversed (from South-East Asia to the US). For Asian currencies linked to the dollar, the higher value of the dollar meant reducing export competitiveness in global markets and balance of payments problems.

Second stage. Soft regulation, market practices. Since December 1996, increased pressure on the national currency forced the central bank to raise interest rates from $5 \%$ to $9 \%$; it partly prevented a capital flight and the BoT has started its foreign exchange interventions to keep the baht's fixed rate still.

The third stage. Administrative restrictions. But in May 1997, in the face of speculative attacks on the currency, the Bank of Thailand introduced restrictions on most of direct cross-border currency transactions, except for international trade and investments. A two-tier foreign exchange market was created, with the fixed rate used for trading and the remaining transactions carried out at the market rate. This did not stop capital flight, but sharply reduced the liquidity of the financial system. The pressure on the national currency was not reduced, so the central bank continued to intervene, and, in 1996-1997, Thailand's international reserves declined from USD 38.6 billion to USD 26.8 billion, or $34 \%$ to $25 \%$ of external debt. 
The fourth stage. Liberalization of the exchange rate. After 2 June 1997, Thailand's central bank introduced a floating exchange rate of the Thai baht, which led to a significant depreciation, further increasing pressure and deepening the debt crisis. Low confidence, uncertainty and panic because of capital movement restrictions only increased outflows, despite the fact that short-term interest rates were risen to over $20 \%$. The collapse of one of the largest financial corporations in the country, Finance One, caused more panic among investors. The banking sector, especially BIBFs, boosted the amplitude of the financial crisis. Commercial banks recorded a net capital outflow of USD 4.7 billion in 1997 and USD 4.3 billion in 1998, at the same time, USD 1.7 billion were withdrawn through BIBFs in 1997 and USD 9.6 billion in 1998 (Figure 5).

\section{Figure 5. Payments dynamics and restrictions on capital movement in Thailand}

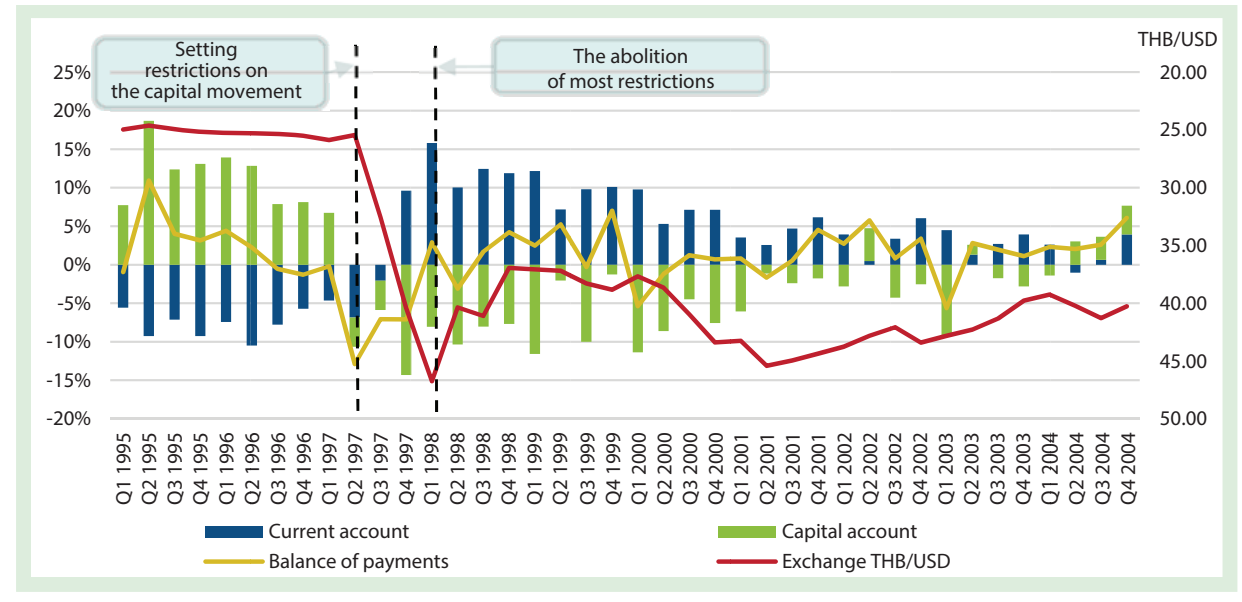

Source: according to the Bank of Thailand.

The fifth stage. Elimination of restrictions. The Bank of Thailand, entering into USD 3.9 billion IMF stand-by program signed 20 August 1997, abolished the dual exchange rate regime practice and the rest of its limitations in early 1998. Subsequently, the central bank increased reserve requirements and strengthened regulations on assets' classification, then required banks to reserve at least $20 \%$ of lending value for each reporting period and fully maintain this level of reserves until 2000 . It created a favorable foundation for further growth and the competitive positions of exports strengthened due to the depreciation.

\section{Conclusions}

Unlike other countries in the region, Thailand failed to prevent a crisis. According to some Thai officials, restrictions introduced on capital movement only deepened the problem. Scientists agree that the restrictions on capital flows were introduced too late and were quite complex, so, rather than producing the desired effect, they caused panic and accelerated the withdrawal of capital.

It is widely recognized that weak supervision of banks and financial corporations and excessive leverage were key reasons for the economy's rapid collapse after the introduction of the floating exchange rate regime.

The Thailand experience is frequently contrasted with Malaysia's practice. These countries are similar in terms of economic development, structure of their economies and financial sectors, they faced similar external problems (generated by unfavorable economic conditions), and internal problems. But, unlike Thailand, Malaysia's anti-crisis policy was much more efficient and appeared able to prevent the outflow of capital and a significant economic downturn. The Malaysian system of restrictions on capital flows leveled any potential gains from speculation in the national currency. The Central bank regained control of capital outflows through early responses to potential threats and floating the currency (rynnhita) that left no significant benefit for currency speculators, as was the case in Thailand where the central bank was trying to maintain the rate. Malaysia was more fortunate during the moment of crisis; it started later than Thailand and its exit out of the crisis coincided with the economic recovery in other countries of the region.

The main objectives of the capital controls system, implemented by the Malaysia Government, were:

- to negate any potential benefits of speculation in the national currency; 
- to eliminate the offshore rynnhita market and dual exchange rates:

- to increase monetary autonomy policy; and

- to insulate the economy from the effects of further deterioration of global financial conditions.

To achieve the goal of completely blocking all cross-border financial transactions, except for trade, Malaysia implemented mandatory sale requirement of foreign currency. Foreign exchange transactions could have taken place only with the permission of the government, for which it was necessary to establish the nature of the trading transaction or that the funds were direct investments.

The main difference between the results of capital controls policy in Thailand and Malaysia were:

- Thailand suffered because of speculative attacks and imposed restrictions on capital movement as a defense mechanism to support the currency. Malaysia, instead, didn't suffer from the extraordinary speculative pressures because, at that time, the exchange rate had not been fixed;

- Restrictions on the capital movement in Malaysia were very broad and intended to destroy all loopholes for the withdrawal of currency. Instead, the restrictions imposed by Thailand, at least in retrospect, were not broadbased. In particular, significant opportunities remained to withdraw currency through BIBFs, there was no adjustment to properly control fictitious foreign transactions, the possibility to withdraw capital through securities and the stock market was not offset; and

- Thailand used restrictions in the midst of the crisis, while the government of Malaysia had introduced it on early stage when financial markets had just begun to decline. The important point here is the last fact. This difference between the moments of restrictions' imposition could be the key factor in explaining the negative results of control policy of the Thai capital movement.

Source: Bank of Thailand (2009); Lauridsen (1998), Jongwanich, Socorro Gochoco-Bautista, Lee (2011), Watanabe, Akama, Mifune (2002), Hali, Edison, Reinhart (2000).

\section{Conclusions}

International experience shows that long-term use of capital control policies have negative consequences for the economy by distorting market conditions and changing the incentives of market participants. Moreover, maintaining such a policy increases government's administrative costs.

Ukraine, whose economy needs major investment resources for development, has the potential to benefit from full financial liberalization. Given the current level of Ukraine's integration into the global economic system and the need to attract large amounts of investment for structural modernization, full liberalization of capital flows is a welcome result of market reforms leading to fully realizing the country's economic potential. In addition, liberalization of capital movement is consistent with the Ukraine's strategic goal of integrating into the EU.

The full liberalization can be reached at different pace depending on the necessary prerequisites. The experience of other countries that liberalized capital movements and IMF precautions should be taken into account. In particular, liberalization is more likely to be successful if it is carried out with closely-coordinated fiscal, monetary, and exchange rate policies while carrying out reforms that enhance the capacity of markets and institutions. It is also important to promote prudential supervision and risk management in the banking system.

International experience also shows that the liberalization policy should be carried out carefully, making it possible for the economic agents to adapt and to implement market reforms. Thus, it is recommended to gradually open access to various capital flows, classifying them as more or less risky for the economy. This liberalization can be quite a lengthy process. Thus, even in Europe full liberalization took place for over 10 years from the beginning of changes. 


\section{References}

- Arvai Z. (2005). Capital Account Liberalization, Capital Flow Patterns, and Policy Responses in the EU's New Member States. Working Paper, No. 05-213, IMF.

- Bank of Thailand (2009). Capital flows in Thailand: Trends, Determinants and Implication for Central Bank Policies. February 2009. Available at: https://www.bot.or.th/Thai/MonetaryPolicy/ArticleAndResearch/DiscussionPaper/ dp022009_thai.pdf\#search=capital\%25201997

- Capital Flows Management: Lessons from International Experience (2013). IMF and PBC Joint Conference Summaries and Presentations, Edited by Rodlauer M., N'Diaye P., March 2013.

- Central Bank of Iceland (2011). Capital Account Liberalization Strategy. Report to the Minister of Economic Affairs. 25 March 2011. Available at: http://www.cb.is/lisalib/getfile.aspx?itemid=8673

- Chinn M., Ito H. (2015). The Chinn-Ito index - a de jure measure of financial openness. Available at: http://web. pdx.edu/ ito/Chinn-Ito_website.htm

- Financial Regulation in the European Union (2016). Edited by Kattel R., Kregel J., Tonveronachi M., Routledge Taylor\&Francis Group, London, UK.

- Hali J., Edison H.J., Reinhart C. M. (2000). Capital Controls During Financial Crises: the Case of Malaysia and Thailand. Available at: http://www.federalreserve.gov/pubs/ifdp/2000/662/ifdp662.pdf

- Hartwell C. (2014). If You're Going through Hell, Keep Going: Non-linear Effects of Financial Liberalization in Transition Economies. Institute for Emerging Markets Studies (IEMS).

- IMF (2012 a, 2013 a, 2014). Annual Reports on Exchange Arrangements and Exchange Restrictions, various issues.

- IMF (2012 b). The Liberalization and Management of Capital Flows: An Institutional View. Staff Policy Paper, No. 14.

- IMF (2012 c). Liberalizing Capital Flows and Managing Outflows. Staff Policy Paper. March 13, 2012. Available at: https://www.imf.org/external/np/pp/eng/2012/031312.pdf

- IMF (2013 b). Guidance Note for the Liberalization and Management of Capital Flows.

- IMF (2015), Iceland: Selected Issues. Country Report No. 15-73, February 20, 2015.

- Jongwanich J., Socorro Gochoco-Bautista M., Lee J.-W. (2011). When are Capital Controls Effective? Evidence from Malaysia and Thailand. Working Paper Series, No. 251, ADB Economics. Available at: http://www.adb.org/sites/ default/files/publication/28804/economics-wp251.pdf

- Klein M. (2012). Capital Controls: Gates versus Walls. Brookings Papers on Economic Activity Fall 2012. https://doi.org/10.1353/eca.2012.0015

- Kokoszczynski R. (2001). From Fixed to Floating: Other Country Experiences: The Case of Poland. Paper to be presented at the IMF seminar Exchange Rate Regimes: Hard Peg or Free Floating? Washington, DC, March 19-20, 2001. Available at: https://www.imf.org/external/pubs/ft/seminar/2001/err/eng/kokos.pdf

- Kose M.A., Prasad E. (2012). Capital Accounts: Liberalize or Not? Finance\&Development. Available at: http://www.imf.org/external/pubs/ft/fandd/basics/capital.htm

- Krugman P. (1998). An open letter to Prime Minister Mahathir. September 1, 1998. Available at: http://web.mit.edu/krugman/www/mahathir.html

- Lauridsen L. (1998). The Financial Crisis in Thailand: Causes, Conduct and Consequences? Available at: http://kumlai.free.fr/RESEARCH/THESE/TEXTE/INEQUALITY/Thailande/The\%20Financial\%20Crisis\%20in\%20Thailand.pdf

- Ma G., McCauley R.N. (2007). Do China's capital controls still bind? Implications for monetary autonomy and capital liberalisation. Working Paper, No. 233, Bank of International Settlements. 
- Ministry of Finance and Economic Affairs of Iceland (2015). Capital Accounts Liberalization Strategy. Available at: https://eng.fjarmalaraduneyti.is/media/frettatengt2015/Capital-Account-Liberalisation-English.pdf

- Obstfeld M. (2015). Trilemmas and Tradeoffs: Living with Financial Globalization. Available at: http://eml.berkeley. edu/ obstfeld/Trilemmas_last\%20draft.pdf

- Ostaszewski P. (2013). Iceland - Political Implications of the Financial Crisis of 2008 and Road to Changes in the Economic Policy and in the Model of Democracy. Forum Scientiae Oeconomia, Vol. 1, No. 1. Available at: http://www.wsb.edu.pl/container/FORUM\%20SCIENTIAE/numer\%201/forum-1-2013-art4.pdf

- Saadi Sedik T., Sun T. (2012). Effects of Capital Flow Liberalization - What is the Evidence from Recent Experiences of Emerging Market Economies. Working Paper, No. 12-275, IMF. https://doi.org/10.5089/9781589068032.001

- Saborowski C., Sanya S., Weisfeld H., Yepez J. (2014). Effectiveness of Capital Outflow Restrictions. Working Paper, No. 14-8, IMF. https://doi.org/10.5089/9781484379752.001

- Watanabe K., Akama H., Mifune J. (2002). The Effectiveness of Capital Controls and Monitoring: The Case of Non-internationalization of Emerging Market Currencies. EMEAP Discussion Paper. Available at: http://www.emeap. org/wp-content/uploads/2015/04/final.pdf

- World Bank (2005). Financial Liberalization: What Went Right, What Went Wrong? Chapter 7 in Economic Growth in the 1990s: Learning from a Decade of Reform. World Bank, Washington, DC.. 


\section{Nowcasting of Economic Development Indicators Using the NBU's Business Survey Results}

\author{
Roman Lysenko \\ National Bank of Ukraine
}

\author{
Nataliia Kolesnichenko \\ National Bank of Ukraine
}

\section{ABSTRACT}

The article explores the possibilities to use Business Outlook Survey results, which are carried out by the National Bank of Ukraine, for the short-term forecasting of economic development indicators, in particular, the Gross Domestic Product of Ukraine. The different methods of building of the leading index of economic development, their advantages, and their restrictions are examined. The choice of the best index, which provides for the higher accuracy of forecasting the GDP, is carried out with the use of econometric models.

\section{JEL Codes: E3, E4, E5}

Keywords: business expectations, business outlook survey, GDP, nowcasting

\section{INTRODUCTION}

The generally acknowledged world practice is the use of survey results of economic agents (including enterprises) concerning the future expectations of economic development for the forecasting of the main macroeconomic variables, such as economic activities, consumption, investments, industrial production, employment, etc.

Usually the expectations are qualitative, that is, non-quantitative data, which characterize the personal assessment by enterprises of their current and forecasted business activity. The questions may concern a wide range of information regarding enterprises activities, flexibly adapt to the analytical needs of the survey's customers, and include information that official statistics do not contain. The main advantage of surveys is that their results usually precede the publication of actual statistical data, which creates the possibility to make a preliminary assessment, for example, of such an indicator as the Gross Domestic Product (hereinafter referred to as GDP).

For this purpose, the surveys are based on leading indicators of economic development in general and under different directions - consumption, investments, demand, employment, etc. - for short-term assessments of economic development, in particular, for assessing turning points of economic cycle. The forecasting horizon may range from one quarter up to one year and depends on the questions' horizon (for the next quarter or year). The expectations under separate questions or indicators are aggregated as the balance of answers - the difference between the share of the respondents' answers who expect the indicator to improve or grow, and the share of the respondents' answers who expect the indicator to worsen or decrease. The aggregate index is the business expectation index and is based on the balances of expectations under several questions.

The most widespread are the following methods of index building:

- With the help of definition of the medium or the average weighted value of the respondents' balance of answers;

- With the help of the principle components method;

- With the help of the factor analysis. 
The key problem of building the business expectation index is defining the list of indicators that shall be taken into account during its composition, and the choice of the most adequate methods of index composition. A large number of indicators complicates the possibilities for index building, and the artificial restriction increases the risk of non-accounting of the essential factors, which influence the dynamics of macroeconomic indicators.

The index example, which is calculated using the medium or the average weighted value of the surveys subjects' assessments, may be the Purchasing Managers' Index, which is used in the Manufacturing ISM Report on Business (more commonly known as PMI ISM in the services sector, production sector, and business activities of the companies registered in New York). This is a composite index of three seasonally adjusted indicators with equal weights. Notwithstanding the sufficiently simple calculation methods, PMI ISM is a quite powerful indicator, which provides the possibility to assess the dynamics of economic development over a short-term period. The obvious advantage of this method is its simplicity; however, a significant risk of influence by subjective factors exists (weight values).

In its turn, the principle components method is also quite widespread and is used for the calculation of the Ifo Business Climate Index (Germany), the Purchasing Managers' Index (the EU), the Synthetic Economic Barometer (Bank of Belgium), and Business Confidence (Reserve Bank of Australia), i.e., in countries where there are no shock transformations and the sharp changes in the economic activities conditions. According to Pichette (2012), the use of the principle components method provides the possibility to avoid subjectivity while choosing indicators, which are included into the index, and that is particularly important during calculation of the weights of the indicators, which are included into the index's composition.

The National Bank of Ukraine (hereinafter referred to as the NBU) has carried out quarterly Business Outlook Survey since 2006. Similar to other institutions that carry out surveys, the NBU calculates the aggregate index of the survey's results - the Business Expectation Index (hereinafter referred to as the BEI), which is based on the enterprises expectations concerning the prospects of their development in the next 12 months, in particular, concerning the financial and economic conditions, volumes of products and services sales, investments, and employment. The BEI is calculated as the average value of the balances of answers. Based on the principles of index building, it must be a leading indicator of economic development with a one year interval, that is, to have the possibility to help in forecasting of GDP. Meanwhile, previous researches (Kolesnichenko, 2010; Petryk \& Kolesnichenko, 2012) certify that the BEI reflects mainly the current economic development. In particular, their calculations indicate on the presence of a significant direct relationship between the BEI and the GDP in the current quarter, and with an increase in the time lag, the relationship deteriorates. Therefore, the current methods of BEI calculation give contradictory results. However, even in such conditions the BEI can be used as the leading indicator of Ukrainian economic development, at least with a lag of one quarter in advance, because the previous assessment of the GDP is published by State Statistics Service of Ukraine (hereinafter referred to as the SSSU) 45 days after the end of the reported quarter, and their expanded assessment after 90 days. Meanwhile, the BEI gives the possibility to carry out the assessment of the GDP already at the end of the current quarter.

The use of the principle components method for building an alternative leading indicator based on the Business Outlook Survey results, theoretically can improve the quality and increase the forecasting horizon of the GDP. This requires analysis of the interconnection between the index's dynamics and the dynamics of real GDP and a comparison with the relationship between the GDP and the BEI. An important step will become the building and assessment of econometric models for the forecasting of GDP and its components with the use of the BEI and the index, built under the principle components method. This will allow for the possibility of reasoned choice the best model for nowcasting of GDP.

This paper is organized as follows: Section II contains a review of the literature devoted to the building of leading indicators under the Business Outlook Survey results and the assessment of the interconnection between such indicators and the actual indicators of economic development, in particular, GDP. Section III outlines the main characteristics of the Business Outlook Surveys, which are carried out by the NBU and cover aggregate index building by the principle components method and analysis of this index. Section IV contains a comparative assessment of the interconnection between the GDP, the BEI and the index built under the principle components method. In the same section are models built for the forecasting of GDP and its components with the use of these indicators, as well as their assessment, which was made based on a reasoned choice of the best index for forecasting GDP over the short-term period. In the last section, the conclusions under the study results are given.

\section{LITERATURE REVIEW}

In studies, where issues of use of Business Outlook Survey are examined for the assessment and forecasting of economic activities indicators (in particular, the dynamics of GDP), as a rule, three main tasks are resolved:

1. Do we need to include the survey results as an additional index into the composition of a complex macroeconomic model or build the model on the basis of only the business expectation index and assess its influence on the macroeconomic variables (for example, GDP)? 
2. Is it appropriate to build an aggregate business expectation index? Will it really have a higher forecasting capability than the enterprises' answers to separate questions, for example, concerning investments, sales volumes, etc.?

3. What method of data aggregation is more appropriate in the context of its further use in the forecasting model?

On the issue of the use of the enterprises' expectations results, a study was conducted by Dovern (2006), who assesses the influence of the business expectation indicators on the forecasting model of the real GDP of Germany (in the annual measurement and up to the previous quarter) and its components. As the business expectation indicators, Dovern chose the aggregated indicators, which are published monthly by the Institute of Economic Researches IFO (Germany), in particular, the business expectation index ${ }^{1}$ (IFO business expectation index). He comes to the conclusion that the inclusion of the aggregated indicators, which reflect business expectations results, significantly improves the characteristics of the forecasting model of changes in GDP compared with the previous quarter. However, when forecasting changes in GDP in annual terms, the inclusion of the business expectation indicators does not lead to improvement of the forecasting characteristics.

Bascos-Deveza (2011), according to the results of carrying out a correlative analysis, makes the conclusion concerning the presence of a high level of correlation between the business expectation index, which is actually the average weighted value of the balance of enterprises answers, and the growth rates of Real GDP in the Philippines. However, in her study the author merely states a higher correlation value between these indicators and does not give a qualitative assessment of the forecasting models of GDP growth rate.

While studying the strengthening of forecasting characteristics of macroeconomic models, Piette and Langenus (2014), using the National Bank of Belgium - BREL ${ }^{2}$ model as an example, received the same results. The authors prove that the inclusion of business expectation indicators into the model composition improves its statistical characteristics, which is particularly important for the assessment of the GDP of the current quarter till the moment of publishing the actual statistical data.

A number of studies are devoted to the study of forecasting characteristics as separate indicators (the balance of answers) of enterprises' business expectations, and the aggregated indicators under the survey's results.

One of the first studies of this problem is the work of a research team from the National Institute of Economic Researches of Sweden (Stockholm) (Hansson, Jansson, and Löf, 2003), which is devoted to the possibility of forecasting the macroeconomic indicators of Sweden (mainly of real GDP) with the help of the business expectation indicators of the Swedish Business Tendency Survey. ${ }^{3}$ The quality of forecasting properties of the business expectation index was received by way of a comparison of the results and the characteristics of three models:

a) a basic VAR-model, in which only the macroeconomic variables (employment level, short-term and long-term interest rates, level of salary, inflation, and exchange rate) were included;

б) a VAR-model, for which the variable was the business expectation index calculated according to a dynamic factor model (DFM);

B) a VAR-model, for which the variable was one of the standard indicators of economic activities - PMI.

The authors state that the qualitative results were received from the VAR-model containing the aggregated index calculated based on a DFM. Moreover, this model allows for the possibility of receiving qualitative forecasting of real GDP not only over the short-term (up to two quarters), but also over long-term periods (up to eight quarters).

The purpose of a study by Kabundi (2004) was defining the possibility of forecasting the Real GDP of France with the help of business expectation indicators, which are collected, processed, and published by the National Bureau of Statistics of France. For building an aggregated business expectation index like in the study of Hansson, Jansson, and Löf (2003), a factor dynamic model GDFM was chosen, with the help of which were defined the principle components for the composite business expectation index (COM). The author defined the correlation level between the composite index and the variable of the Real GDP of France in annual terms as 0.86 . The forecasting characteristics of the COM business expectation index for GDP are assessed with the help of a comparison using a random walk model. The researcher concluded that the resulting indicator enables forecasting quarterly GDP for France with a rather high accuracy.

\footnotetext{
${ }^{1}$ Reflects companies' expectations in the field of production, construction, and trade for the next six months.

${ }^{2}$ BRidge equations with predictors selected on the basis of an Elastic net procedure.

${ }^{3}$ This survey is carried out by Swedish Bureau of Statistics.
} 
In their study, Greef and Nieuwenhuyze (2009) examined the benefits of an indicator of the National Bank of Belgium according to Business Surveys results, which is actually the average weighted index. The authors state that in general it is sufficient to review only the weights of separate questions as part of the aggregated index's composition. The use of other approaches, in particular the principle components method, is not reasonable because that method does not improve results and is difficult for society to understand.

Etter and Graff (2011) stress to the contrary the convenience of interpretation of the aggregated business expectation index, which is built with the help of the principle components method for the Peruvian economy. The researchers used this method for the construction of a leading composite indicator for the Peruvian economy based on business tendencies surveys, which are carried out by the National Reserve Bank of Peru. The authors are limited only by their statement of the correlative analysis results, which certifies the close relationship between the growing rates of Real GDP and the resulting indicator, which constitutes 0.85 . The forecasting assessments of GDP with the help of this indicator were not presented in the study.

Pichette and Rennison (2011) devoted a study to the issue of forecasting business activities indicators (the growth rates of Real GDP and investments) with the help of processing survey results concerning business expectations. For obtaining the aggregated index concerning enterprises' business expectations according to survey results of the Bank of Canada (Business Outlook Survey, hereinafter referred to as BOS), the authors use the principle components method and justify the use of the first principle component use (PC1) as an effective indicator of economic activities, in particular, for the assessment of enterprises' investment costs. This result is extremely important because it is usually difficult to forecast the change in the aforementioned index, and the number of indicators for its assessment is limited. This partially explains the fact that in the majority of other works (Hansson, Jansson, and Löf, 2003; Kabundi, 2004; and others), the main macroeconomic index is GDP. Additionally, Pichette and Rennison concluded that the question concerning future sales volumes and investments into equipment contain useful information for the forecasting of Real GDP dynamics and investments in the real economy sector. These indicators' inclusion into the correspondent forecasting models of GDP and its components (particularly investments) strengthens the forecasting accuracy and improves the model's statistical assessments.

The next study by Pichette (2012) was devoted to the problem of choosing the most optimal methods for building the aggregated index of enterprises' business expectations. The author compares the forecasting characteristics of the aggregated indicators, which are built with the help of tree main methods, namely: simple average, the principle components method, and factor analysis. The resulting information is assessed with the help of regressive analysis. On the basis of comparing forecasting assessments from each model, the author makes the conclusion that all three approaches give the very similar results and have almost equal forecasting assessments.

Bec and Mogliani (2013) conducted a study on the issue of forecasting the real GDP of France with the help of separate business activity indicators. One of the tasks of this study was a results comparison for the forecasting of the quarterly GDP of France on the condition that only separate components of aggregated business expectation indicators were included into the linear regressive model's composition. These components are published by the Bank of France, the National Bureau of Statistics, and the Markit Purchasing Managers Index. The study also included a comparison of the results obtained from the model, whose structure included all components of aggregated indicators of the aforementioned business expectations surveys (Fullinformation models). The results certify significantly more qualitative statistical characteristics of Full-information models, in particular, $\mathrm{R}^{\wedge} 2$ (adjusted) is equal to 0.89 , while the model in which the separate indicators were used does not exceed 0.75 . The RMSE value was also minimal for Full-information models, which gives grounds for making, among others, a conclusion about the reasonability of inclusion of indicators from survey results of different institutions (notwithstanding the number of questioned enterprises) into the composition of the forecasting model.

Piette and Langenus (2014) came to the conclusion that the study's results on the issue of business activity forecasting of Belgium do not give convincing arguments concerning the advantage of including aggregated indicators into the model's indicators. The authors state that the disaggregated data of enterprises' answers are more informative and give more qualitative assessments in comparison to the aggregated indicators.

Summarizing the literature review, we can make the following conclusions. First, the inclusion of enterprises' expectations results into a forecasting model of macroeconomic indicators (above all others is real GDP) is reasonable. Second, there is no common approach concerning the calculation methodology or components of such an index. This may be justified both by the peculiarities of the economic systems structure (for example, the importance of the services sphere for forecasting the GDP of Belgium, and hence the importance of the answers from this sector's representatives). Simultaneously, none of the researchers received convincing arguments against the concept that an aggregated index, calculated according to complex methods (such as the principle components method or the factor dynamic model), has higher qualitative forecasting characteristics than the average weighted or even separate balances of answers. 


\section{DATA, CALCULATIONS OF AGGREGATED INDICATORS, AND THEIR ANALYSIS}

The NBU carried out quarterly Business Outlook Survey since 2006. About 900 enterprises of the non-financial economic sector in 22 regions ${ }^{4}$ participate in survey, chosen so that they reflect the economic structure ${ }^{5}$ by regions and type of economic activity. The survey results are the enterprises assessments and expectations concerning the current situation and prospects for development (such as sales volumes, investments, employment), macroeconomic tendencies (in particular, inflation and exchange rate expectations), and the estimation of the links with the banking system of Ukraine (the needs for funding, credit conditions assessment, etc.). ${ }^{6}$

The main advantage of the survey is the receipt of information, which comes quicker, taking into account that the surveys are carried out in the middle of the quarter, or even absent in official statistics. This gives the grounds for using the survey results as a leading indicator, including for monetary policy decision-making. The other benefits of the survey results are their voluntariness and confidentiality. That is, we may expect that the survey results reflect a true assessment by the managers of both the situation of the enterprise and the economic environment. This gives the possibility to assess the conditions under which economic agents made decisions concerning their plans and not to make an adjustment for their possible shadow activities.

The information received under the survey results is transformed from qualitative information into quantitative data by calculating the net balance of answers. A growing balance of answers and a positive balance indicate positive changes in the economy, while a decreasing balance of answers and a negative balance indicates negative changes.

Since 2010, the NBU calculates the BEI concerning the prospects for enterprise development in the next 12 months. The results of the works of Kolesnichenko (2010) and Petryk \& Kolesnichenko (2012) certify the presence of a significant direct correlation between the BEI and the GDP in the current quarter. However, these results are contradictory because these enterprises should provide forecasts of their development for a year after the survey's date and do not reflect the current situation. But, even under such conditions, the BEI can be used as a leading indicator of the Ukrainian economy's development, at least, for one quarter in advance, because the preliminary assessment of the GDP is published by the SSSU 45 days after the end of the reported quarter, and its expended assessment after 90 days.

\section{Transformation of survey results into quantitative indicators}

The calculation of the net balance of answers on question $i$ is made using the formula:

$$
A_{i}=\frac{s_{i}^{+}-s_{i}^{-}}{s_{i}}=a_{i}^{+}-a_{i}^{-},
$$

where $A_{i}$ - is the balance of answers to question $\mathrm{i}, s_{i}^{+}-$is the amount of enterprises who answered that the index would improve/grow, $s_{i}^{-}$- is the amount of enterprises who answered that the index would worsen/decrease, $s_{i}-$ is the total amount of enterprises who answered question $\mathrm{i}$. Thus, $a_{i}^{+}-$is the share of enterprises expecting a growing index, and $a_{i}^{-}-$is the share of enterprises expecting a decreasing index (in percentage).

The BEI is calculated as the average balance of expectations to questions concerning the prospects of the enterprise development in the next 12 months under the formula:

$$
B E I=\sum_{i=1}^{5} A_{i}+100
$$

Upon calculation of the $\mathrm{BEI}$, the balances of answers for the following questions are used:

1) How would you assess the financial and economic conditions of your enterprise in the next 12 months?

2) How will the total volume of products (services) sales of your enterprise change in the next 12 months?

3) How will the investments for building change at your enterprise in the next 12 months?

4) How will the investments for machinery, equipment and instruments change at your enterprise in the next 12 months?

5) How will the number of employees change at your enterprise in the next 12 months?

\footnotetext{
${ }^{4}$ Except the Autonomous Republic of Crimea, Donetsk and Luhansk regions.

${ }^{5}$ The NBU uses quota sampling, which is formed proportionally to the region's contribution and the concrete activity type in the production of the gross added value of Ukraine.

${ }^{6}$ The survey methodology is explained in detail in the "Methodological Principles of Surveys Concerning the Business Outlook by the National Bank of Ukraine" at: http:// www.bank.gov.ua/doccatalog/document?id=76819
} 
For composition the aggregated index using the principle components method based on the survey's results, the extended questions list (Table 1) was used in comparison with those use for calculating the BEl. According to the theoretical assumptions, all of these questions are characterized by a correlation with the economic activities in the country. All data are the quarterly results of the enterprises' surveys for the period from the 2nd quarter of 2006 till the 3rd quarter of 2015.

\section{Table 1. Questions used for calculating the index under the principle components method}

\begin{tabular}{|l|l|}
\hline No. & \\
\hline $\mathbf{A 1}$ & How would you assess the current financial and economic condition of your enterprise? \\
\hline $\mathbf{A 2}$ & How would you assess the financial and economic condition of your enterprise in the next 12 months? \\
\hline $\mathbf{A 3}$ & How will the total volumes of products (services) sales of your enterprise change in the next 12 months? \\
\hline $\mathbf{A 4}$ & How will the total volumes of products (services) sales of your enterprise change at the external market in the next 12 \\
\hline $\mathbf{A 5}$ & months? \\
\hline $\mathbf{A 6}$ & What is the current level of inventory of finished goods in comparison with the desired level? \\
\hline $\mathbf{A 7}$ & How will the investment for buildings change at your enterprise in the next 12 months? \\
\hline $\mathbf{A 8}$ & How will the investments for machinery and equipment change at your enterprise in the next 12 months? \\
\hline $\mathbf{A 9}$ & How will the number of employees change at your enterprise in the next 12 months? \\
\hline $\mathbf{A 1 0}$ & How will unit costs at your enterprise change in the next 12 months? \\
\hline $\mathbf{A 1 1}$ & How will the need for borrowed money to finance your activities change in the next 12 months? \\
\hline $\mathbf{A 1 2}$ & How have the conditions for receiving financing from banks for your enterprise changed over the last three months? \\
\hline $\mathbf{A 1 3}$ & What are the enterprise's plans with regard to obtaining loans? \\
\hline
\end{tabular}

The idea of the principle components method consists of reducing the dimensions of the input data matrix while providing maximum retention of information. The description of the calculation algorithm of the principle components is set out, in particular, at Stock and Watson (2002) and Pichette (2012). In general, the principle components $\mathrm{a}_{\mathrm{j}}[\mathrm{j}=1 \ldots \mathrm{k}]$ are the linear combination of the input variables $x j(j=1, \ldots, n)$. One of this method's peculiarities is the impairment of useful information with the components order, that is, it is actually reasonable to examine only the first several components (as a rule - not more than the first four).

In our case, the first three components describe about $84 \%$ of the actual value dynamics (Figure 1), which makes it reasonable to focus only on their analysis according to Kaiser's Rule.

\section{Figure 1. Contributions of principle components}

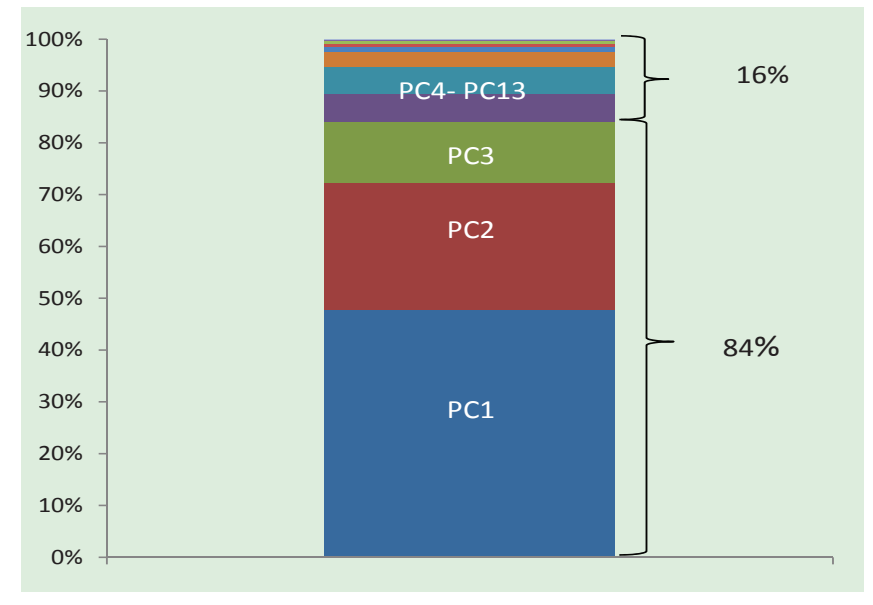

Source: NBU staff estimates under the surveys results. 
The influence of each of the questions A1-A13 on the dynamics of principle components is using correspondent coefficients or weights (Table 2, Figure 2). Because each of the principle components is orthogonal (that is, perpendicular) to one another, the coefficients in each principle component change accordingly. An analysis of each component structure and the coefficients comprising a part of each of the three principle components shows the following.

Table 2. Coefficients values in the principle components structure

\begin{tabular}{|c|c|c|c|}
\hline Indicators & pc1 & pc2 & $p$ c3 \\
\hline A7 & 0.378284 & 0.15514 & 0.029207 \\
\hline A8 & 0.374323 & 0.13509 & 0.041912 \\
\hline A9 & 0.373807 & 0.166187 & 0.049064 \\
\hline A2 & 0.346234 & 0.087475 & 0.116725 \\
\hline A3 & 0.345504 & -0.25284 & 0.051414 \\
\hline A4 & 0.326348 & -0.28299 & 0.052355 \\
\hline A1 & 0.300891 & 0.24508 & 0.119373 \\
\hline A13 & 0.236324 & -0.3864 & 0.056431 \\
\hline A11 & 0.22871 & -0.10799 & -0.37935 \\
\hline A12 & 0.084745 & 0.506187 & -0.05053 \\
\hline A10 & 0.000756 & -0.00492 & -0.73463 \\
\hline A6 & -0.10368 & 0.494853 & 0.179853 \\
\hline A5 & -0.12113 & -0.23716 & 0.489953 \\
\hline
\end{tabular}

Figure 2. Weights (coefficients) of questions A1-A13 in the composition of the first three principle components

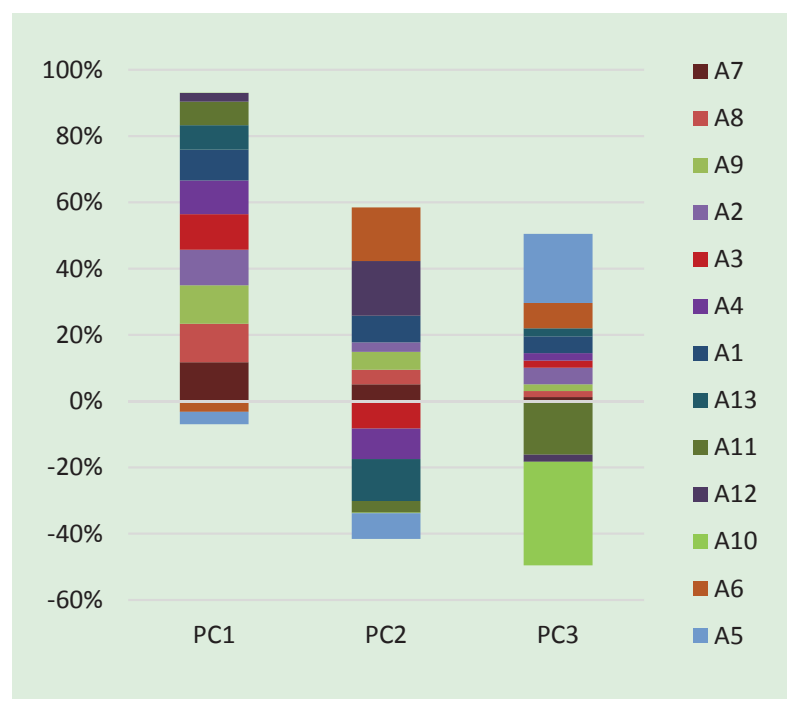

Source: NBU staff estimates under the survey results. 
The first principle component (PC1) correlates with the majority of variables, which can be used for the assessment and forecasting of economic activities, in particular:

-all forecasting estimates of enterprises' management for one year:

- The change of the investments for building and equipment (A7 and A8);

- The change of the number of employees (A9);

- The change of the financial and economic conditions of the enterprise (A2);

- The change of the total volumes sales (A3);

- The change of the volumes sales in the external market (A4).

- The assessment of the current financial and economic conditions of the enterprise (A1).

From an economic point of view, such a structure of the first principle component is fully acceptable, because usually investments increase, employment rises, and sales volumes increases lead to a growth in economic activities (in particular, the GDP), and the current development of enterprises influences the assessment of future prospects.

Simultaneously, the influence of the change in crediting conditions is quite insignificant, which is explained both by the complexity of enterprises' access to credit resources for the last 7 years, and their high value. The negative influence on economic activities in the PC1 structure has the increase of idle capacity at the enterprise (A6) and the increase of volumes of inventories (A5), which is also considered as justified.

Taking into account the previously mentioned, the first principle component can be used as a leading indicator of economic activities.

\section{Figure 3. PC1 and Real GDP Growth (y-0-y), \%}

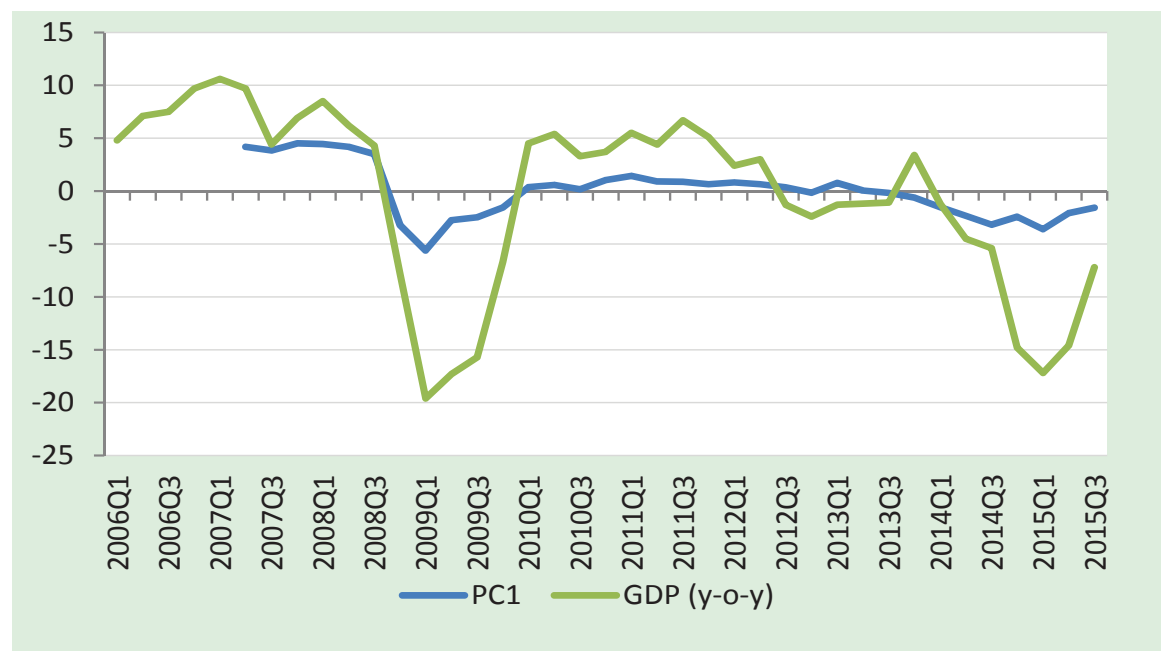

Source: NBU staff estimates under the survey results.

The structure of the second principle component (PC2) corresponds more to the task of assessing the influence of the financial conditions on economic activity. Thus, the key factors influencing this component's value are the complexity of enterprises' access to financing from banks (A12), that is, the rigidity of credit conditions, as well as the increase in idle capacity (A6).

The analysis of the PC2 dynamics (Figure 4), certifies that since the 3rd quarter of 2010 the crediting conditions almost do not influence GDP dynamics and business activities in Ukraine. Actually, started from this period, extremely unfavorable conditions for loans were formed, which have not changed up to today. Under such conditions, enterprises are not interested in borrowing to support and/or to stimulate the development of their own activities. Also of interest is the analysis of the balance of credit conditions and enterprises' plans concerning obtaining loans during 2007-2009. After intensification of the financial and economic crisis in 2008, enterprises suffered from significant problems related to the availability of credit resources, which were balanced by lower demand for these resources. So the PC2 value approximated to zero, because enterprises' plans concerning borrowing (A13) and the changes in expectations of products sales volumes ( $\mathrm{A} 3$ and $\mathrm{A} 4$ ) were leveled by the complexity of access to banking resources (A12) and the capability to satisfy unexpected demand (A6). 
Figure 4. PC2 and Real GDP Growth (y-o-y), \%

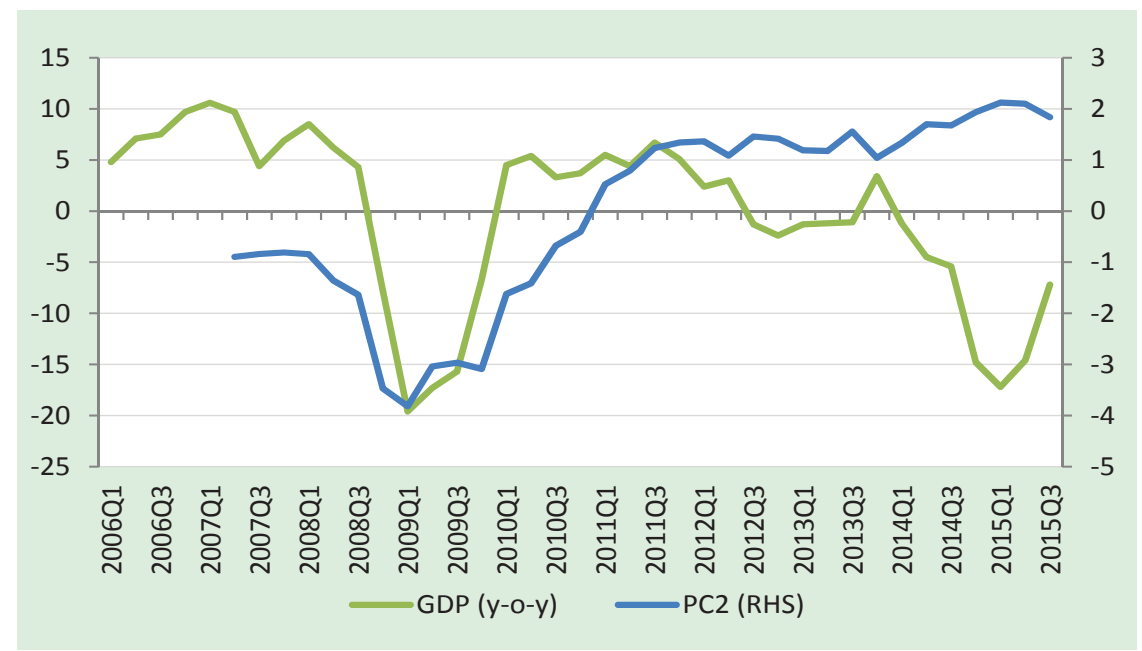

Source: NBU staff estimates under the survey results.

The key factors influencing the third principle component value (PC3) are the change of the unit costs at enterprises in the next 12 months (A10) and the level of inventories (A5). The change of unit costs was included into the index composition with a negative sign (Table 2 ), because growing costs may negatively influence business activity.

The analysis of the third principle component dynamics (PC3) and GDP (Figure 5) certifies that, before the 1st quarter of 2014, enterprises' expectations concerning the increase of unit costs were neutral to economic activity. Generally, this is typical for small commodity-oriented economies, where prices and demand for products are formed in external markets. The sharp devaluation of the hryvnia exchange rate and the subsequent increase of a unit cost, combined with the simultaneous fall of world prices and demand for Ukrainian export products, formed the corresponding enterprises' expectations (the negative significant influence of unit cost, which was not compensated by other factors), which for the first time in the history of observations coincided with the GDP dynamics in the country.

Figure 5. PC3 and Real GDP Growth (y-o-y), \%

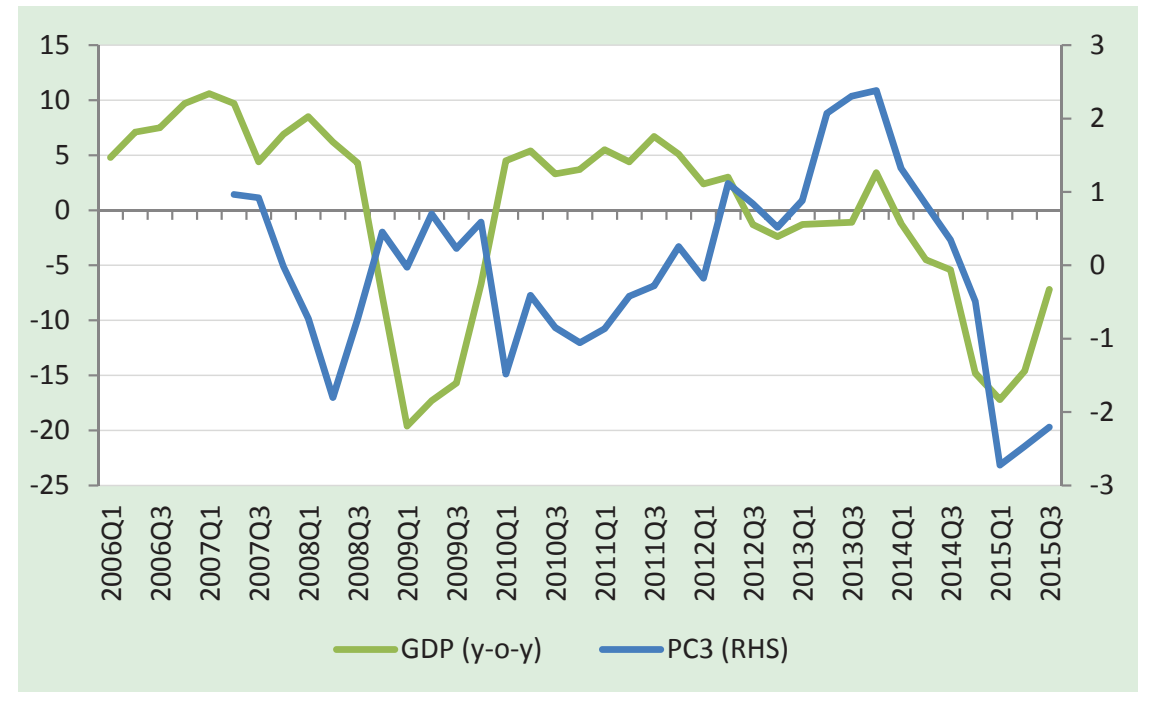

Source: NBU staff estimates under the survey results. 
The greatest deviations between GDP dynamics and first three principle components are observed during the periods of the greatest crisis aggravation in Ukraine, that is, in the 4th quarter of 2008, the 1st quarter of 2009, and the 1st-2nd quarters of 2015. Typical for all periods is the overestimation of crisis influence by enterprises, which within stable periods provided enterprises expectations better than macroeconomic indicators (except 2013, when the expectations worsened quicker than the level of business activities decreased).

\section{USE OF THE AGGREGATED INDICATORS TO FORECAST GDP}

To assess the forecasting power of the constructed PC1 indicator and its comparison with the BEI forecasting power, a correlation analysis of these indicators and real GDP was carried out (Table 3). The closest relationship was found between the change of GDP and the BEI and PC1 in the current quarter. Therefore, the relationship between GDP and the BEI is somewhat better in comparison with the connection between the GDP and PC1. In addition, a closer correlation is observed between the $\mathrm{BEI}, \mathrm{PC1}$, and the change of GDP y-o-y (to the corresponding quarter of the previous year), which is connected with the 12-month horizon of questions, thus, the seasonality has already been excluded from the survey results.

\section{Table 3. Correlation Between BEI, PC1, and Real GDP Growth}

\begin{tabular}{|c|c|c|c|c|}
\hline Lag & \multicolumn{2}{|c|}{ GDP (q-o-q, SA) } & \multicolumn{2}{c|}{ GDP $(\mathbf{y}-\mathbf{0}-\mathbf{y})$} \\
\hline & BEI & PC1 & BEI & PC1 \\
\hline $\mathbf{- 4}$ & 0.1346 & -0.0220 & 0.1020 & -0.0444 \\
\hline $\mathbf{- 3}$ & 0.4587 & 0.3483 & 0.2702 & 0.1543 \\
\hline $\mathbf{- 2}$ & 0.6525 & 0.5588 & 0.4789 & 0.3857 \\
\hline $\mathbf{- 1}$ & 0.7350 & 0.6470 & 0.7289 & 0.6524 \\
\hline $\mathbf{0}$ & 0.7103 & 0.6201 & 0.9105 & 0.8580 \\
\hline $\mathbf{1}$ & 0.3248 & 0.2114 & 0.8344 & 0.7461 \\
\hline $\mathbf{2}$ & 0.0024 & -0.0841 & 0.5918 & 0.4881 \\
\hline $\mathbf{3}$ & -0.1130 & -0.2552 & 0.3099 & 0.1772 \\
\hline $\mathbf{4}$ & -0.1847 & -0.3628 & 0.0023 & -0.1726 \\
\hline
\end{tabular}

Figure 6. BEI, PC1, and Real GDP Growth (y-o-y), \%

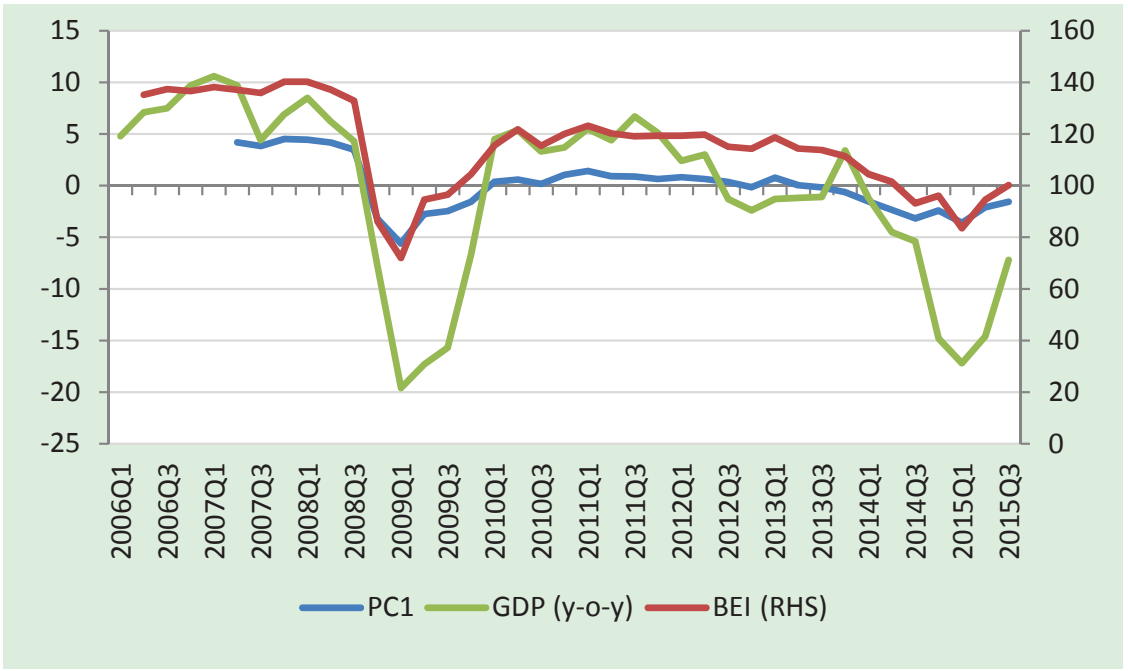

Source: NBU staff estimates under the survey results. 
Figure 7. BEI, PC1, and Real GDP Growth (q-o-q, SA), \%

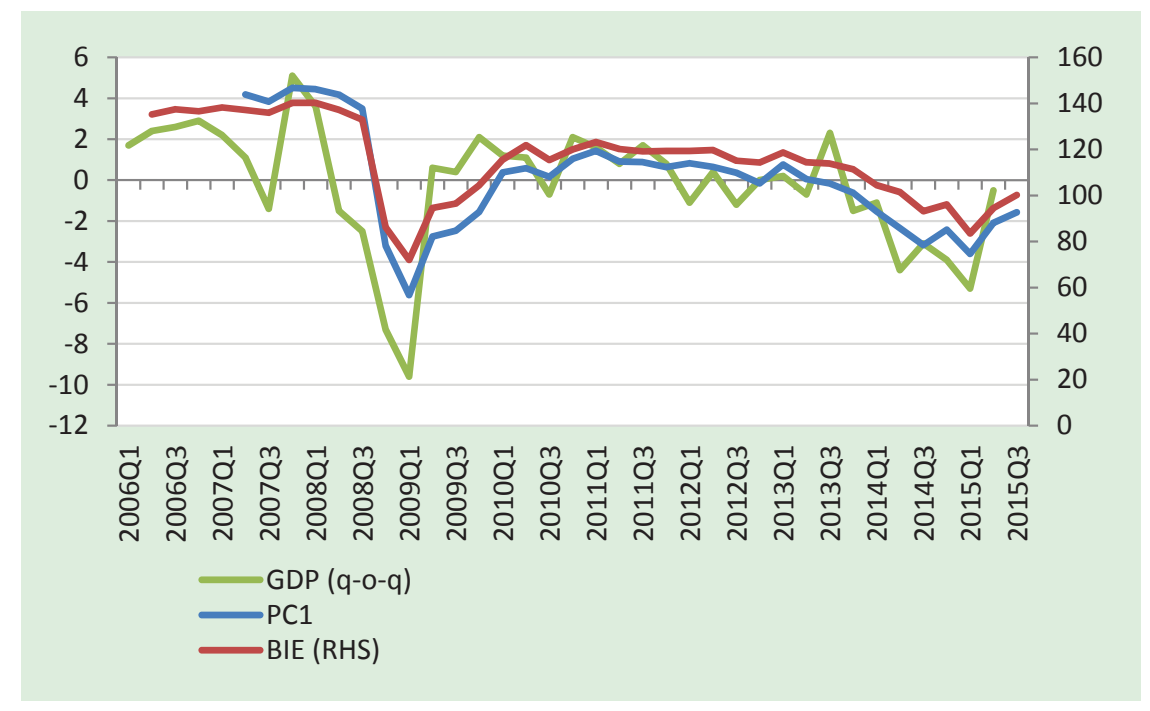

Source: NBU staff estimates under the survey results.

The tight relationship between the indicators of GDP, the BEI and PC1 gives the possibility of their use for nowcasting of economic development. For this purpose, we have built linear regression equations for a different set of indicators:

- On the basis of GDP (baseline for a forecast quality assessment) ${ }^{7}$ :

$G D P_{t}=c_{1}+\alpha_{1} \times G D P_{t-1}+\varepsilon_{t 1}(1)$,

- On the basis of PC1:

$G D P_{t}=c_{2}+\alpha_{2} \times G D P_{t-1}+b_{2} \times P C 1_{t}+\varepsilon_{t 2}(2)$,

- On the basis of the balance of answers concerning total sales volumes (BA):

$G D P_{t}=c_{3}+\alpha_{3} \times G D P_{t-1}+b_{3} \times B A_{t}+\varepsilon_{t 3}(3)$,

- On the basis of the BEI:

$G D P_{t}=c_{4}+\alpha_{4} \times G D P_{t-1}+b_{4} \times I D O_{t}+\varepsilon_{t 4}(4)$.

The next step was building the corresponding equations for GDP components - the final consumption expenditure (hereinafter referred to as consumption) and the gross fixed capital formation (hereinafter referred to as investments) under the same principle. As the balance of answers for the equation (3) concerning consumption uses the balance of answers related to total sales volumes, and for investments - the balance of answers concerning investments for building. The equations were built separately for the different values of GDP and its components: the changes compared with the corresponding quarter of the previous year (hereinafter $y-0-y$ ) and compare with the previous quarter, seasonally adjusted (hereinafter - q-o-q). In building PC1, the equations were assessed for the period from the 2nd quarter of 2006 to the 3rd quarter of 2015.

The statistical characteristics for the basic equation (1) for GDP, investments, and consumption both q-o-q and y-o-y (Table 4) indicate a sufficiently weak capability of the AR(1) model. This means that the forecasting model strength must be increased by the inclusion of additional variables, in particular, indicators that characterize the business expectations.

${ }^{7}$ Represents the autoregressive equation $A R(1)$. 
Table 4. Statistical properties of the equations ${ }^{8}$

\begin{tabular}{|c|c|c|c|c|c|c|}
\hline & $\begin{array}{l}G D P_{t} \\
q / q\end{array}$ & $\begin{array}{l}G D P_{t} \\
y / y\end{array}$ & $\begin{array}{l}\ln v_{t} \\
q / q\end{array}$ & $\begin{array}{l}\ln v_{t} \\
y / y\end{array}$ & $\begin{array}{c}\text { Cons }_{t} \\
q / q\end{array}$ & $\begin{array}{c}\text { Cons }_{t} \\
y / y\end{array}$ \\
\hline C & $\begin{array}{c}-0.14 \\
{[-0.34]}\end{array}$ & $\begin{array}{c}-0.34 \\
{[-0.45]}\end{array}$ & $\begin{array}{c}-1.17 \\
{[-0.71]}\end{array}$ & $\begin{array}{c}-1.17 \\
{[-0.62]}\end{array}$ & $\begin{array}{c}0.36 \\
{[0.65]}\end{array}$ & $\begin{array}{c}-0.36 \\
{[-0.39]}\end{array}$ \\
\hline$G D P_{t-1} q / q$ & $\begin{array}{l}-0.53 \\
{[3.78]}\end{array}$ & & & & & \\
\hline$G D P_{t-1} y / y$ & & $\begin{array}{c}0.85 \\
{[9.65]}\end{array}$ & & & & \\
\hline $\ln v_{t-1} q / q$ & & & $\begin{array}{c}0.34 \\
{[2.14]}\end{array}$ & & & \\
\hline $\ln v_{t-1} y / y$ & & & & $\begin{array}{c}0.85 \\
{[10.25]}\end{array}$ & & \\
\hline Cons $_{t-1} q / q$ & & & & & $\begin{array}{c}0.39 \\
{[2.32]}\end{array}$ & \\
\hline Cons $_{t-1} y / y$ & & & & & & $\begin{array}{c}0.89 \\
{[10.56]}\end{array}$ \\
\hline$R^{2}$ (adjusted) & 0.28 & 0.89 & 0.12 & 0.75 & 0.14 & 0.76 \\
\hline RMSE-ratio & 2.87 & 3.41 & 10.07 & 20.51 & 3.41 & 9.72 \\
\hline
\end{tabular}

The inclusion of the business survey indicators - the first principle component (PC1) (equation 2), the separate balances of answers (BA) (equation 3), and the BEI (equation 4) improved the assessments and the statistical properties of the basic model both for GDP and its components investments and consumption significantly (Table 5). This concerns quarterly and annual measurements of the forecasting indicators.

The best results were received from equations that included the BEI (except investments), which is unexpected because the BEI is the just simple average of the balances of answers. Thus, such a conclusion corresponds to the results of Greef and Nieuwenhuyze (2009), who insisted on the inadvisable use of the principle components method, as well as Pichette (2012), who did not receive convincing arguments as to the benefit of this method.

For investments, the qualitative properties are shown by the equation that included the balance of expectations concerning investments in building. Such a result corresponds to the conclusions of Pichette (2012) and Piette and Langenus (2014) in the context of the more self-descriptiveness and forecasting power of the separate balances of answers, but not the aggregated indicators.

The results also confirmed the availability of a statically significant correlation between the enterprises' expectations and the business activity in the reporting quarter $t$, that is, the expectations are adaptive and depend on the current situation and the past development, and do not reflect the forecast over the next year. This result is consistent with the results of other studies, in particular, Kabundi (2004), Piette and Langenus (2012), Pichette (2012), and others.

The statistical assessments and the properties both of the equations and the separate indicators in whole are adequate and correspond to the results received by other researchers. Simultaneously, a value of statistical properties of the equations are worse than by other researchers (in particular, in the work of Pichette (2012) for the GDP of Canada). However, taking into account the significant structural changes in the Ukrainian economy and the shock drop of GDP through the crises in 2008-2009 and 2014-2015, this is a sufficiently acceptable result. 
Table 5. Statistical properties of the extended equations ${ }^{9}$
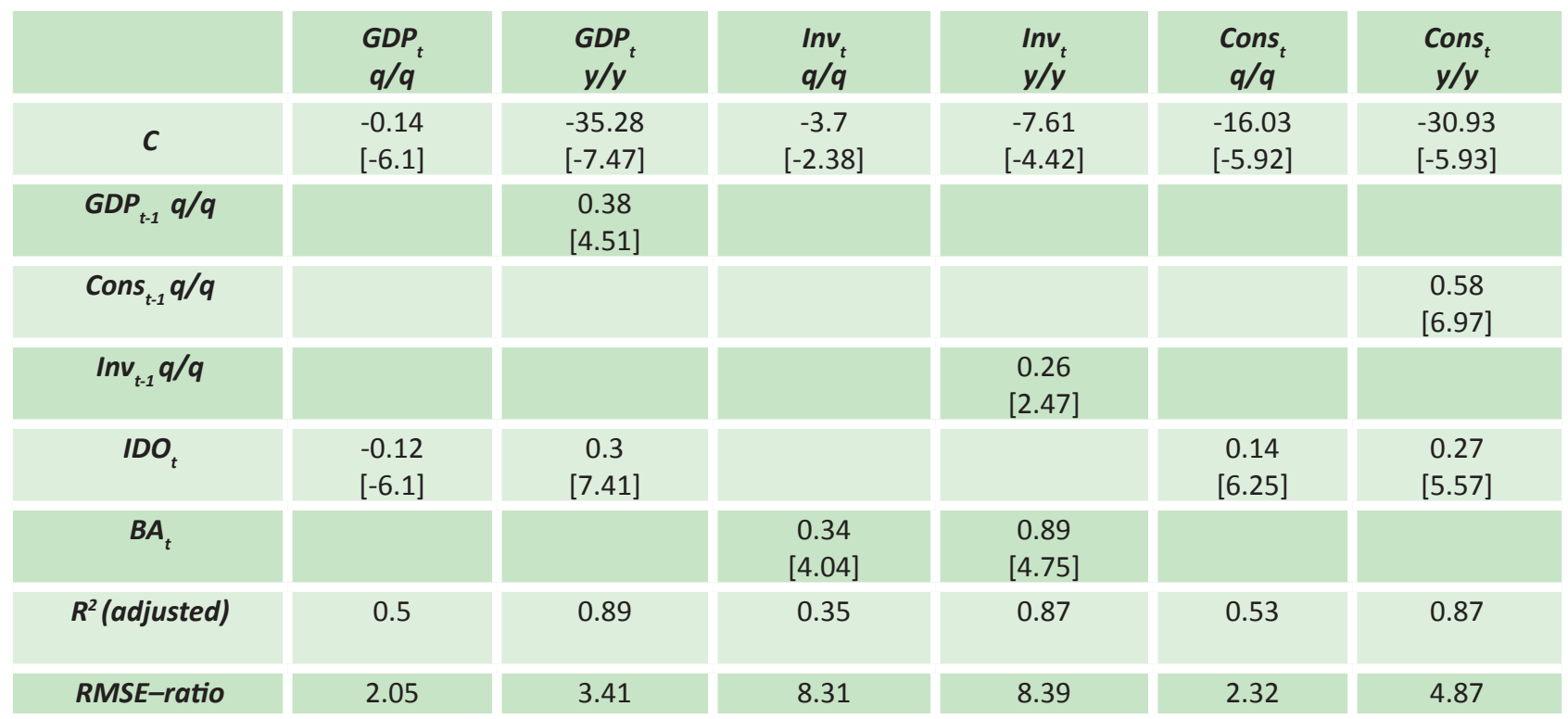

The results certify that the BEI calculation approach, which were accepted in the NBU, provide better forecast of the GDP dynamics and consumption as the GDP component than the index built under the principle components approach. Thus, the BEl can be used for nowcasting of GDP and its components with help of the developed equations. Thus, the sufficiently high RMSE values are probably the consequences of the high volatility of GDP, consumption, and investments within the period, which is the basis for the calculations.

\section{CONCLUSIONS}

The study conducted had the purpose of checking the possibility of using Business Outlook Survey results, which are carried out by the NBU since 2006, for nowcasting of Ukrainian GDP and its components (investments and consumption). The study's results provide the possibility to make the following conclusions.

First, the survey results have strong power for forecasting Ukrainian business activity. The statistical properties of the equations, which included aggregated business expectation indicators or the separate balance of answers, were much better than the results of the basic model. On the other hand, the results certify that enterprises' forecasting assessments rather reflect their current situation and not the development over the next 12 months. Thus, enterprises' expectations in Ukraine are adaptive, that is, depend on the current situation and the past development. This conclusion was expected as almost the same results were received in the most of studies concerning the use of survey results in the forecasting of economic development.

Second, the business expectation index BEI, which is calculated by the NBU, is the actual simple average of the balances of answers to questions concerning the prospects of enterprises' activities over the next 12 months, provides for changes of GDP and consumption as the GDP component with more reliability than the index calculated under the principle components method (the first principle component). Thus, the BEI can be fully used for nowcasting of GDP using the developed equation. This result is unexpected, because an increase of the index components list theoretically allows for the possibility to more accurately take into account the influence of the smallest changes in different indicators on change in GDP. Thus, this does not contradict the results of Pichette (2012) studies and agrees with the conclusions both of Greef and Nieuwenhuyze (2009) concerning the inadvisable use of the principle components method, and Piette and Langenus (2014) in the context of the more convenient use of separate balances of answers for building models than the aggregated indicators.

Third, using the principle components method proved to be useful only for the assessment of the extended factors list, which nevertheless influenced the dynamics of business activities. In particular, the first principle component is based on the current assessment and the forecast; the second one is more connected with the complexity of access to financing from banks, which gives the possibility to assess the influence of financial conditions on economic activities. The key factors influencing the value of the third principle component are the unit costs and the level of inventories, which gives the possibility to assess the influence of demand and the producers prices fluctuation on the economic development.

\footnotetext{
${ }^{9}$ The values in the Table - calculated coefficients; value in brackets [] - t-statistics.
} 


\section{References}

- Banerjee A., Marcellino M., Masten I. (2003). Leading Indicators for Euro-area Inflation and GDP Growth. Working Paper, No. 235.

- Bascos-Deveza T. (2011). Quantifying qualitative data from expectation surveys: how well do expectation surveys forecast inflation? IFC Bulletin, No. 34, Bank for International Settlements, pp. 128-137.

- Burkart O., Coudert V. (2000). Leading Indicators of Currency Crises in Emerging Economies, Banque de France.

- Cesaroni T. (2010). Estimating potential output using business survey data in a SVAR framework. Economics Bulletin, Vol. 30, No. 3, pp. 2249-2258.

- Chamberlin G. (2007). Forecasting GDP using external data sources. Economic \& Labour Market Review, Vol. 1, No. 8, Office for National Statistics, pp. 18-23.

- Cheung C. (2009). Are Commodity Prices Useful Leading Indicators of Inflation? Discussion paper / Document d'analyse, No. 2009-5, Bank of Canada.

- Etter R., Graff M. (2011). A composite leading indicator for the Peruvian economy based on the BCRP's monthly business tendency surveys. Working Paper series, No. 2011-006 (Serie de Documentos de Trabajo), Banco Central de Reserva del Peru.

- Greaf I., Nieuwenhuyze C. (2009). The National Bank of Belgium's new business survey indicator, National Bank of Belgium.

- Hansson J., Jansson P., Löf M. (2003). Business Survey Data: Do They Help in Forecasting the Macro Economy? Working Paper, No. 84, The National Institute of Economic Research.

- Klein L., Ozmucur S. (2004). Some Possibilities for Indicator Analysis in Economic Forecasting. Oxford University Press, pp. 243-257.

- Kolesnichenko N. (2010). Composition of a synthetic index by results of business expectations surveys conducted by the National Bank of Ukraine. Visnyk of the National Bank of Ukraine, No. 6, pp. 6-9.

- Martin M. (2004). The Bank of Canada's Business Outlook Survey. Bank of Canada Review, pp. 3-8.

- Martin M., Papile C. (2004). The Bank of Canada's Business Outlook Survey: An Assessment, Bank of Canada Review, Working Paper, No. 2004-15 / Document de travail, No. 2004-15.

- Moon H., Lee J. (2013). Forecast evaluation of economic sentiment indicator for the Korean economy, IFC Bulletin, No. 36, Bank for International Settlements, pp. 180-190.

- Petryk O., Kolesnichenko N. (2012). Business surveys as a forecasting and communication mechanism of a central bank. Visnyk of the National Bank of Ukraine, No. 11, pp. 3-11.

- Pichette L. (2012). Extracting Information from the Business Outlook Survey Using Statistical Approaches. Discussion paper / Document d'analyse, No. 2012-8, Bank of Canada.

- Pichette L., Rennison L. (2011). Extracting Information from the Business Outlook Survey: A Principal-Component Approach, Bank of Canada Review, Autumn 2011, pp. 21-28.

- Stock J.H., Watson M.W. (1989). New Indexes of Coincident and Leading Economic Indicators, NBER Macroeconomics Annual, Vol. 4, pp. 351-394.

- Stock J.H., Watson M.W. (2002). Forecasting Using Principal Components From a Large Number of Predictors, Journal of the American Statistical Association, Vol. 97, No. 460, pp. 1167-1179.

- Stock J., Watson M. (2002). Macroeconomic Forecasting Using Diffusion Indexes. Journal of Business and Economic Statistics, No. 20, pp. 147-162. https://doi.org/10.1198/073500102317351921 